University of Nebraska - Lincoln

DigitalCommons@University of Nebraska - Lincoln

$11-16-2017$

\title{
Quaternary sea-level history and the origin of the northernmost coastal aeolianites in the Americas: Channel Islands National Park, California, USA
}

Daniel R. Muhs

Jeffrey S. Pigati

R. Randall Schumann

Gary L. Skipp

Naomi Porat

See next page for additional authors

Follow this and additional works at: https://digitalcommons.unl.edu/usgsstaffpub

Part of the Geology Commons, Oceanography and Atmospheric Sciences and Meteorology Commons, Other Earth Sciences Commons, and the Other Environmental Sciences Commons

This Article is brought to you for free and open access by the US Geological Survey at DigitalCommons@University of Nebraska - Lincoln. It has been accepted for inclusion in USGS Staff -- Published Research by an authorized administrator of DigitalCommons@University of Nebraska - Lincoln. 


\section{Authors}

Daniel R. Muhs, Jeffrey S. Pigati, R. Randall Schumann, Gary L. Skipp, Naomi Porat, and Stephen B. DeVogel 


\title{
Quaternary sea-level history and the origin of the northernmost coastal aeolianites in the Americas: Channel Islands National Park, California, USA
}

\author{
Daniel R. Muhs ${ }^{a, *}$, Jeffrey S. Pigati ${ }^{a}$, R. Randall Schumann ${ }^{a}$, Gary L. Skipp ${ }^{a}$, Naomi Porat ${ }^{b}$, \\ Stephen B. DeVogel ${ }^{\mathrm{c}}$ \\ ${ }^{a}$ U.S. Geological Survey, MS 980, Box 25046, Federal Center, Denver, CO 80225, USA \\ ${ }^{\mathrm{b}}$ Geological Survey of Israel, 30 Malkhe Israel St., Jerusalem 95501, Israel \\ ${ }^{c}$ Amino Acid Geochronology Laboratory, Institute of Arctic and Alpine Research, University of Colorado, Boulder, CO 80309, USA
}

\begin{abstract}
A B S T R A C T
Along most of the Pacific Coast of North America, sand dunes are dominantly silicate-rich. On the California Channel Islands, however, dunes are carbonate-rich, due to high productivity offshore and a lack of dilution by silicate minerals. Older sands on the Channel Islands contain enough carbonate to be cemented into aeolianite. Several generations of carbonate aeolianites are present on the California Channel Islands and represent the northernmost Quaternary coastal aeolianites on the Pacific Coast of North America. The oldest aeolianites on the islands may date to the early Pleistocene and thus far have only been found on Santa Cruz Island. Aeolianites with well-developed soils are found on both San Miguel Island and Santa Rosa Island and likely date to the middle Pleistocene. The youngest and best-dated aeolianites are located on San Miguel Island and Santa Rosa Island. These sediments were deposited during the late Pleistocene following the emergence of marine terraces that date to the last interglacial complex $(\sim 120,000 \mathrm{yr}$ to $\sim 80,000 \mathrm{yr})$. Based on radiocarbon and luminescence dating, the ages of these units correspond in time with marine isotope stages [MIS] 4, 3, and 2. Sea level was significantly lower than present during all three time periods. Reconstruction of insular paleogeography indicates that large areas to the north and northwest of the islands would have been exposed at these times, providing a ready source of carbonate-rich skeletal sands. These findings differ from a previously held concept that carbonate aeolianites are dominantly an interglacial phenomenon forming during high stands of sea. In contrast, our results are consistent with the findings of other investigators of the past decade who have reported evidence of glacial-age and interstadial-age aeolianites on coastlines of Australia and South Africa. They are also consistent with observations made by Darwin regarding the origin of aeolianites on the island of St. Helena, in the South Atlantic Ocean, more than a century and a half ago.
\end{abstract}

\section{Introduction}

"Aeolianite" is a term that originated with Sayles (1931), based on his studies on Bermuda, where such deposits make up the bulk of the island's subaerially exposed parts. Sayles (1931) defined aeolianite as any wind-deposited sediment that is cemented into rock. Thus, in principle, pre-Quaternary, continental-interior, silica-cemented, quartzose sandstones with an aeolian origin could be considered "aeolianite." In practice, however, the term has been restricted to precisely the kind of sediments that Sayles (1931) studied on Bermuda, namely carbonatecemented aeolian sand of Quaternary age along coastlines. Such deposits are not extensive over large areas except in Australia (see Playford et al. 2013; Brooke et al. 2014, and Bourman et al. 2016), nor are they on a par volumetrically with silicate-rich dune fields or sand seas (Fig. 1). However, they have a widespread occurrence globally and are found at multiple localities, primarily in subtropical to temperate latitudes (between about $15^{\circ}$ and $40^{\circ}$, both north and south of the equator; Brooke 2001), and they occur in some tropical latitudes as well.

Darwin observed and described aeolianites in southwestern Australia, South Africa, St. Helena, and Ascension Island on his voyage on HMS Beagle in the 1830s (see discussion in Fairbridge 1995). Since then, many researchers have studied aeolianites worldwide, resulting in a large number of publications summarized in reviews by Fairbridge and Johnson (1978), Gardner (1983), McKee and Ward (1983), Fairbridge (1995), Brooke (2001), Loope and Abegg (2001), Bird (2005), McLaren (2007), Playford et al. (2013), Brooke et al. (2014), and Bourman et al. (2016). Authors in the present study have examined

\footnotetext{
* Corresponding author.

E-mail address: dmuhs@usgs.gov (D.R. Muhs).
} 

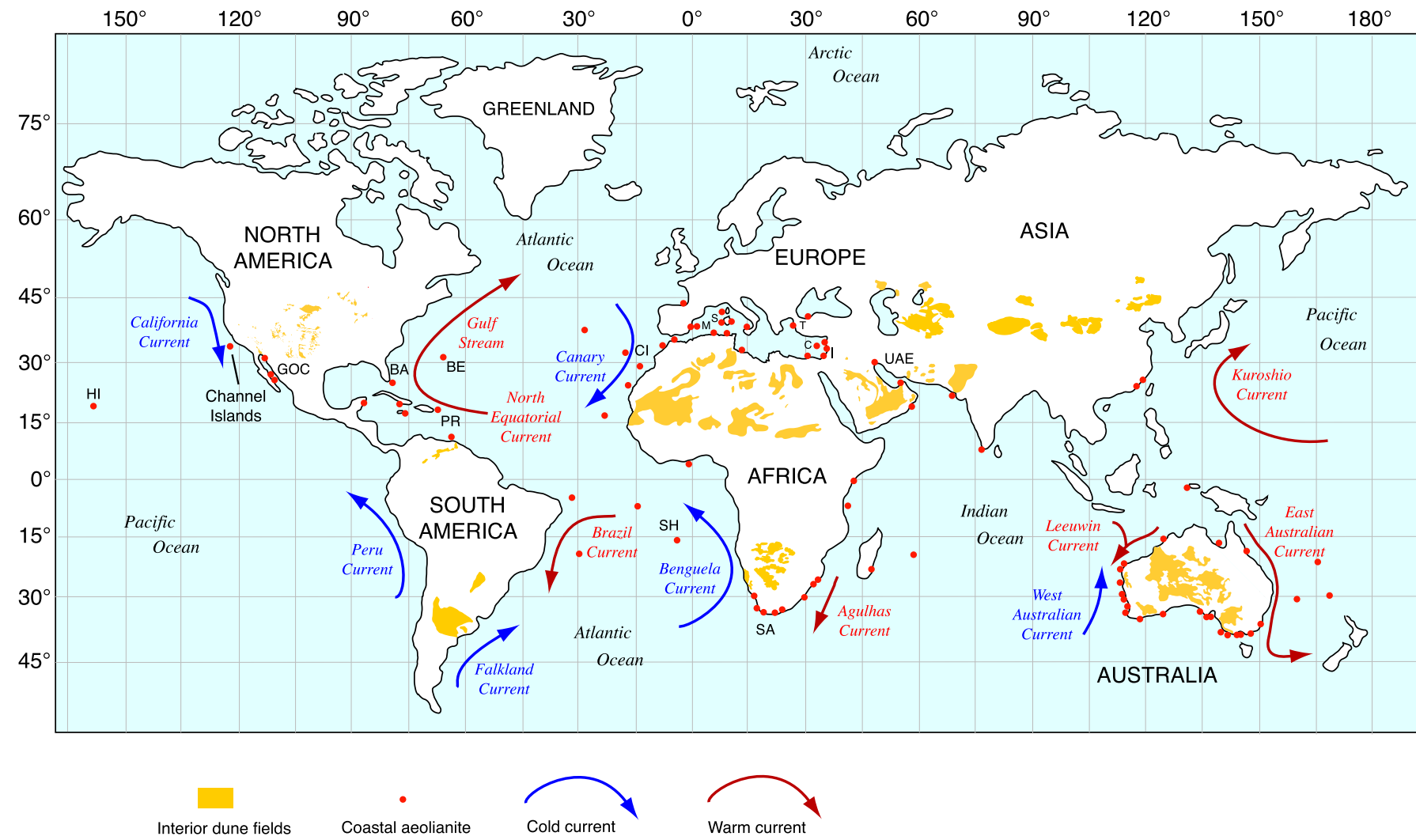

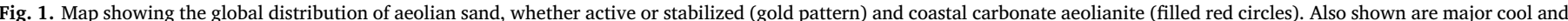

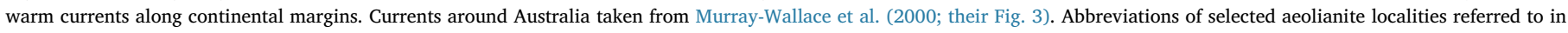

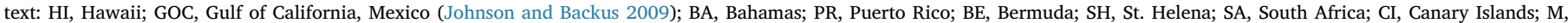

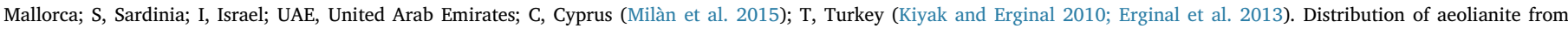

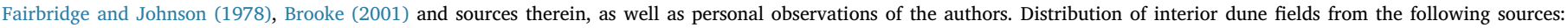

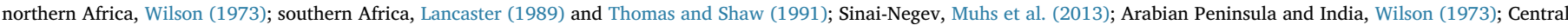

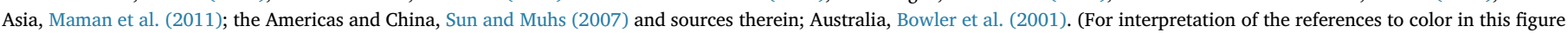
legend, the reader is referred to the web version of this article.)

aeolianites on Bermuda, the Bahamas, Puerto Rico, the Canary Islands, Mallorca, Sardinia, Israel, the United Arab Emirates, South Africa, Hawaii, around the Gulf of California, Mexico, and on the California Channel Islands, the focus of the current study.

Aeolianites are common on islands, where bank or shelf sediments are characterized by high biological productivity and detrital carbonate grains are not diluted by continental siliceous sediment (Fig. 1). This explains the extensive aeolianites on Bermuda, the Bahamas, Caribbean islands, the Canary Islands, and Mediterranean islands, among others. An important exception to this is Australia, where aeolianites are extensive, but also where streams provide very little silicate sand to beaches and continental shelves, which are rich in biogenic carbonate particles (Collins 1988; James and Bone 2011; Brooke et al. 2014; Murray-Wallace 2014; Short 2014; Bourman et al. 2016).

Common to all aeolianites is a relatively high carbonate content compared to typical silicate-mineral-dominated aeolian sands. In Australia, aeolianites of the Bridgewater Formation have carbonate contents (by volume) of 66-99\% (Blakemore et al. 2015). Aeolianites on Mallorca have carbonate contents as high as $90-95 \%$ (Muhs et al. 2010) and those on Bermuda range from 94 to $99 \%$ (Muhs et al. 2012a). On the Bahamas, aeolianites we have studied are $100 \%$ calcium carbonate. Clastic skeletal aragonite and calcite particles comprise much of the carbonate component of aeolianites worldwide, but in addition, secondary, low-Mg calcite is the main cementing agent. Skeletal carbonate grains can be derived from mollusks, echinoderms, corals, algae, or foraminifera, but in some places (notably the Bahamas), they are composed of inorganically precipitated aragonite ooids or peloids. In other environments, such as on Mallorca, they are composed of both skeletal carbonate grains and detrital sands derived from pre-Quaternary limestones. In still other environments, although well cemented, aeolianites are low in carbonate content. For example, some aeolianites on the Mediterranean coast of Israel have as little as 15-30\% carbonate content (Porat et al. 2004), although others in that region have 42-54\% carbonate (Yaalon 1967).

Geomorphically, aeolianites are often expressed as transverse or parabolic dunes (e.g., Murray-Wallace et al. 2010; Nichol and Brooke 2011; Playford et al. 2013; Bourman et al. 2016; Brooke et al. 2017), as is the case with many other coastal dunes. Because of early carbonate cementation, primary sedimentary structures, such as crossbeds, often show spectacular preservation, and thus allow for easy reconstruction of paleowinds, based on foreset bed dip azimuths. Secondary structures are also common in aeolianites, and consist of carbonate root casts (rhizoliths), carbonate fracture-fills, and paleosols. As with other aeolian sands, paleosols mark periods of land-surface stability and vegetation cover, during times when aeolian deposition had ceased or was at least minimal. Similar to calcareous loess deposits, land snails are commonly found in aeolianites, and are often well preserved in the carbonate-dominated host sediment.

The relation between aeolianite formation and sea level has been controversial (see reviews in Fairbridge and Johnson 1978; Gardner 1983; Fairbridge 1995; Brooke 2001; McLaren 2007; Brooke et al. 2014), and concepts have evolved considerably over time. The idea that at least some aeolianites could have formed during periods of lower sea level (i.e., glacial periods) can be found in studies dating as far back as the 19th century. Darwin (1844) studied these deposits on the island of St. Helena in the southern Atlantic Ocean, on the return voyage of 
H.M.S. Beagle in the 1830s. He noted that deposits at elevations of $\sim 180 \mathrm{~m}$ to $\sim 210 \mathrm{~m}$ were composed of carbonate skeletal sands cemented into what would now be called aeolianite, and inferred that they must be of windblown origin. In addition, he noted (p. 87) that:

It is remarkable that at the present day, there are no shelly beaches on any part of the coast, whence calcareous dust could be drifted and winnowed; we must, therefore, look back to a former period, when, before the land was worn into the present great precipices, a shelving coast, like that of Ascension, was favourable to the accumulation of shelly detritus.

At the time Darwin made these observations and even when he wrote about them years later, modern concepts of Pleistocene glaciation had yet to be conceptualized and the idea of an "ice age" was still controversial. Indeed, the first linkage between full-glacial conditions and a lower sea level that results from large ice sheet growth had only just been published (Maclaren 1842; originally published in Scotland in 1841). Nevertheless, Darwin correctly inferred that a source of sand, no longer available, must have existed at some time in the past.

On Bermuda, where the term "aeolianite" was first applied, Sayles (1931) also considered the deposits to have formed primarily during glacial periods, when sea level was lower and an exposed insular shelf provided bioclastic sands to generate dunes. Bretz (1960) and Land et al. (1967) rejected this view and proposed that Bermudan aeolianites are strictly interglacial features, a concept for that island that has persisted into even relatively recent studies (e.g., see Hearty and Olson 2011). However, on Bermuda, although Vacher (1973) accepted the general model of Bretz (1960) and Land et al. (1967) of aeolianite formation during interglacial periods, he pointed out (p. 374) that sea level had to be at least slightly below its present level at the time of dune formation. Indeed, Vacher and Rowe (1997) pointed out that Holocene dunes from the present interglacial are sparse and suggested that major aeolian deposition will come later, when sea level begins to fall, at the inception of a future glacial period. Rowe and Bristow (2015a, 2015b), using detailed sedimentological data, demonstrated that past aeolianite deposition on Bermuda likely occurred as sea level was falling after interglacial periods. Fletcher et al. (2005) reported a similar sequence of events on Molokai, Hawaii.

On some coastlines, aeolianite formation is clearly tied to interglacial periods. In the Bahamas, Garrett and Gould (1984) showed that emergent, Pleistocene beach or marine deposits grade laterally into aeolianites, implying a link to interglacial periods. Carew and Mylroie (1997) proposed a more complex timing, with Bahaman aeolianites forming first during an interglacial transgression and then again as sea level starts to fall. U-series datings of ooids from both beach and aeolianite facies in the Bahamas confirms ages that are similar (Muhs et al. 2007), which supports these general models. In South Australia, aeolianites are considered to be an aeolian facies of the same barrier complexes where interglacial marine deposits are found (MurrayWallace et al. 1999; Blakemore et al. 2015; Bourman et al. 2016). Older barrier complexes in South Australia also have been correlated with older interglacial high-sea stands (Price et al. 2001; Murray-Wallace et al. 2010; Blakemore et al. 2015; James and Bone 2015).

Studies done in the past couple of decades show that aeolianites on some coastlines have considerable complexity with regard to their timing and sea-level history. In Western Australia, investigations by Playford et al. (1976, 2013), Playford (1988, 1997), Price et al. (2001), Brooke et al. (2014), and Ward et al. (2016) show that aeolianites were deposited during interglacial, interstadial, and glacial periods. Aeolianite formation during interstadial or glacial periods off the coast of Western Australia, when sea level was below present, is supported by mapping, submarine exploration, and sonar work that demonstrate the presence of these deposits offshore (Brooke et al. 2010, 2017; Nichol and Brooke 2011). In South Africa, optically stimulated luminescence (OSL) dating also indicates that aeolianite deposition has a complex timing, occurring during interglacial, interstadial, and glacial periods
(Bateman et al. 2004, 2011; Porat and Botha 2008; Roberts et al. 2008; Carr et al. 2010). Furthermore, as is the case in Western Australia, submerged aeolianites, at depths as great as $\sim 130 \mathrm{~m}$, have been documented off the coast of South Africa (Cawthra et al., 2014).

Dune fields are common along much of the Pacific Coast of North America, including Washington, Oregon, California, and Baja California (Cooper 1958, 1967; Kasper-Zubillaga and Zolezzi-Ruiz 2007; Backus and Johnson 2009). Despite the extensive distribution of aeolian sand on this coast, the only carbonate-rich aeolian sands of which we are aware are those found on the California Channel Islands, and in limited areas in Baja California (Russell and Johnson 2000; Kasper-Zubillaga and Zolezzi-Ruiz 2007; Johnson and Backus 2009) (Fig. 1). Elsewhere, such as most of coastal Oregon and central California, aeolian sands are dominated by quartz and feldspar or locally by heavy minerals (Twenhofel 1946; Orme and Tchakerian 1986; Muhs et al. 2009). On the Channel Islands, however, carbonate contents of beach and aeolian sands are high and some of these sands are cemented into aeolianite (Johnson 1967, 1972, 1977; Muhs 1983, 1992; Muhs et al. 2009).

Johnson (1967, 1972, 1977), Muhs (1983, 1992), and Muhs et al. (2009) hypothesized that aeolianites on the Channel Islands may have formed during glacial periods, when sea level was low. In this scenario, carbonate sands first accumulate on insular shelves during interglacial periods, when sea level is relatively high. During a succeeding glacial period when sea level is lowered, shelf sediments are exposed to onshore winds, and carbonate-rich dunes accumulate. This hypothesis contrasts with the concept, still held by some workers, that aeolianites are dominantly tied to interglacial high stands of sea (James and Jones 2016). Indeed, despite the work of the past few decades cited above, both Hearty and O'Leary (2008; p. 26) and James and Bone (2016; p. 33) stated that aeolianite formation during interglacial periods was a "prevalent" global view.

With regard to the model of a glacial-age timing of aeolianite formation on the California Channel Islands described above, there are uncertainties. The geochronology of aeolianites on San Miguel Island reported by Johnson (1977) was limited in scope and that reported by Muhs (1992) on the southern Channel Islands was of an experimental nature. Stratigraphic and geochronologic studies of aeolianites on Santa Rosa and Santa Cruz Islands have not been conducted at all. To provide a more definitive test of the hypothesis of glacial-age aeolianite on the Channel Islands, we describe the results of stratigraphic, mineralogic, and geochronologic studies of aeolianites combined with new mapping efforts on San Miguel Island, Santa Rosa Island, and Santa Cruz Island, California.

\section{Aeolianites on the California Channel Islands}

The California Channel Islands lie off the coast of southern California and mark the northernmost occurrence of coastal carbonate aeolianite in North America and indeed in the Western Hemisphere (Figs. 1, 2). Aeolianites are found on San Miguel, Santa Rosa, Santa Cruz, San Nicolas and San Clemente Islands. The deposits are most extensive on the outermost two islands, San Miguel Island and San Nicolas Island. Thicknesses range from a couple meters to as much as $\sim 20 \mathrm{~m}$. As is the case with most aeolianites worldwide, the carbonate particles in Channel Islands aeolianites are composed of skeletal fragments of marine organisms. Total carbonate contents (aragonite and calcite) range from as little as $\sim 25 \%$ (some parts of San Nicolas Island; Muhs et al. 2009) to as much as $\sim 80 \%$ (San Miguel Island; see below).

Carbonate-rich beach sands, dunes, and aeolianites on the California Channel Islands result from these islands being situated within what is called a "cool-water carbonate factory" (James and Jones 2016). It is well known that carbonate production by marine organisms along coastlines is very high in tropical latitudes, and such systems constitute what are called "warm water carbonate factories" (James and Jones 2016). Hermatypic (reef-building) corals and calcareous green algae dominate carbonate production in warm waters of tropical ocean 

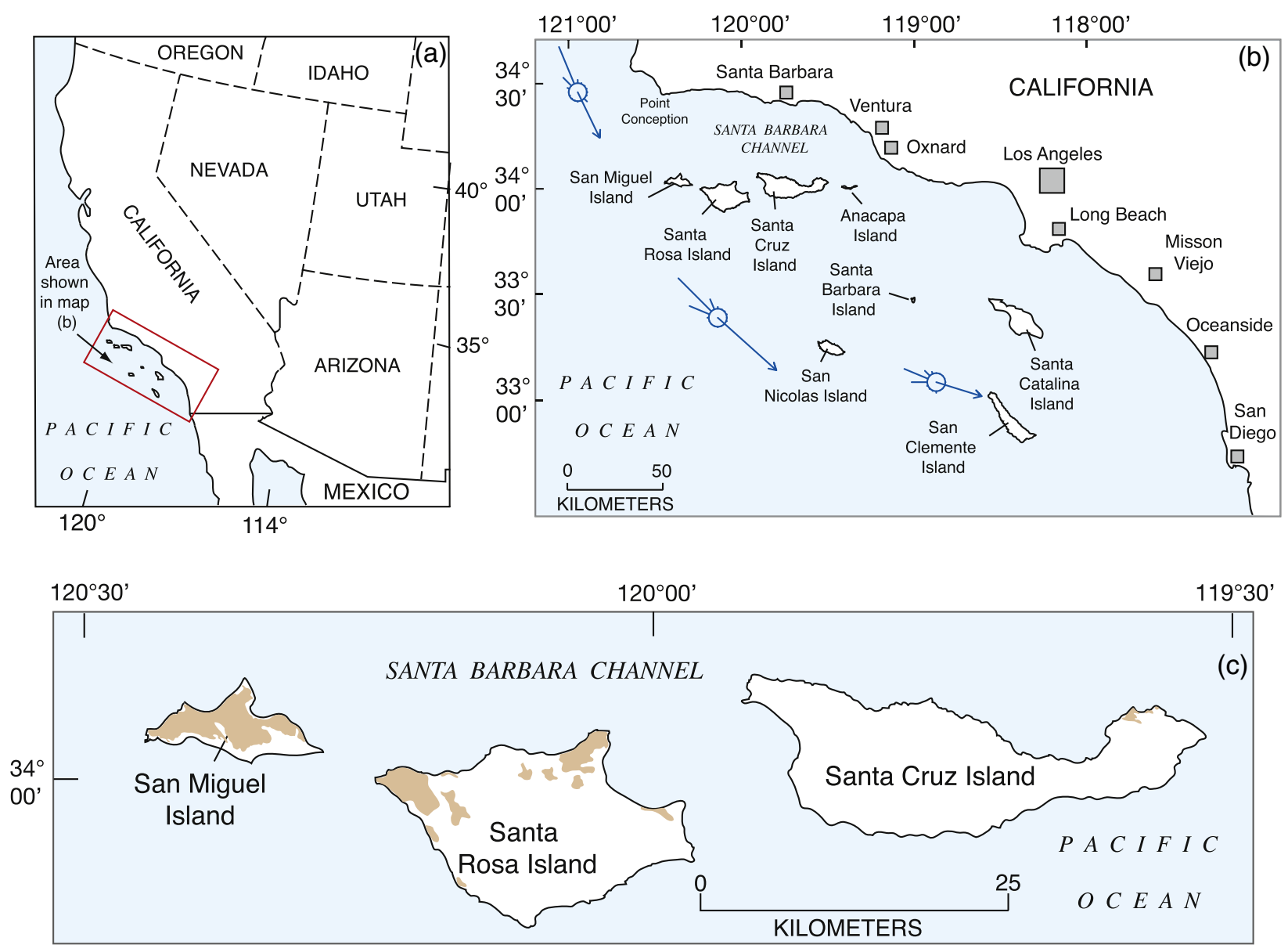

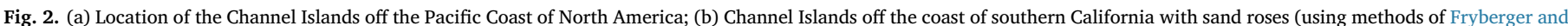

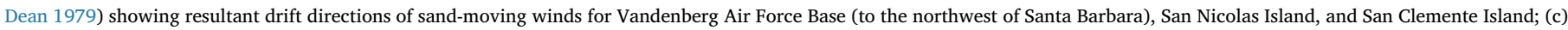
maps of San Miguel, Santa Rosa, and Santa Cruz Islands, showing generalized distribution of aeolianite and aeolian sand (taken from Figs. 3, 18, and 25, respectively).

margins. As a result, there are many carbonate-rich dunes and aeolianites found along tropical and subtropical coastlines where reefs supply skeletal carbonate sand to beaches and shelves (Fig. 1). Nevertheless, several decades ago, Chave (1967) challenged the older, widely held concept that marine carbonate production is important only in tropical latitudes and showed that significant amounts of carbonate sediment are also generated in cool, higher-latitude regions of the oceans. Thus, the concept of "cool-water carbonates" has arisen within the marine sedimentology community (James 1997; James and Jones 2016). In contrast to the coral- and algae-dominated organisms of warm-water environments, carbonate-producing organisms in cool-water environments include mollusks, foraminifers, echinoderms, bryozoans, barnacles, ostracods, sponges, worms, coralline (red) algae, and ahermatypic corals. All of these organisms occur off the California coast in the rich rocky intertidal, protected-bay, and kelp forest environments of the eastern Pacific Ocean (Ricketts et al. 1985).

Around the California Channel Islands, marine invertebrates of carbonate composition are dominated by those taxa that thrive in highenergy, rocky-intertidal environments. Marine organisms around the Channel Islands in the modern intertidal community are similar to those found in intertidal communities elsewhere along the Pacific Coast of North America (Littler 1980). Not only do such communities thrive in rocky intertidal environments today but they did so in the past as well (for example, see faunal lists in Vedder and Norris 1963 and Muhs et al. 2002a, 2006, 2012b, 2014). Submarine shelves with rich accumulations of cool-water carbonate sediments, similar to the Channel Islands, have been identified off many higher-latitude coasts (James and Jones 2016).
Carbonate-rich dunes and aeolianites of Quaternary age have been mapped on San Nicolas Island (Vedder and Norris 1963; Muhs et al. 2009), San Clemente Island (Muhs 1983), and three of the northern islands, including Santa Cruz Island (Weaver et al. 1969), Santa Rosa Island (Muhs et al. 2014), and San Miguel Island (Muhs et al. 2014, their Fig. 5, but modified in the present study). On the northern Channel Islands, the spatial extent of aeolian sand decreases from west to east (Fig. 2c). The landscape of San Miguel Island is dominated by aeolian sand, whereas it is sparse on Santa Rosa Island, and only very small patches occur on Santa Cruz Island. Today, active aeolian sand on these islands is limited to relatively small areas on San Miguel Island landward of Simonton Cove (Fig. 3) and one area to the southeast of Cuyler Harbor (Fig. 4). On San Miguel Island, aeolian sand was active over much of the island in the first part of the 20th century, but this was due largely to reactivation of previously stabilized sand from vegetation removal by overgrazing (Johnson 1980; Zellman 2014). Our studies were focused on San Miguel Island, but we also provide new mapping, stratigraphy, mineralogy, and ages for Santa Rosa Island and some new observations of aeolianites on Santa Cruz Island.

\section{Methods}

\subsection{Field methods}

Aeolian sand units were delineated on San Miguel Island and Santa Rosa Island using National Park Service color aerial photographs acquired in 2002 and 1:24,000 USGS topographic maps of the islands as mapping bases in the field. Soil maps generated by Johnson (1972, 


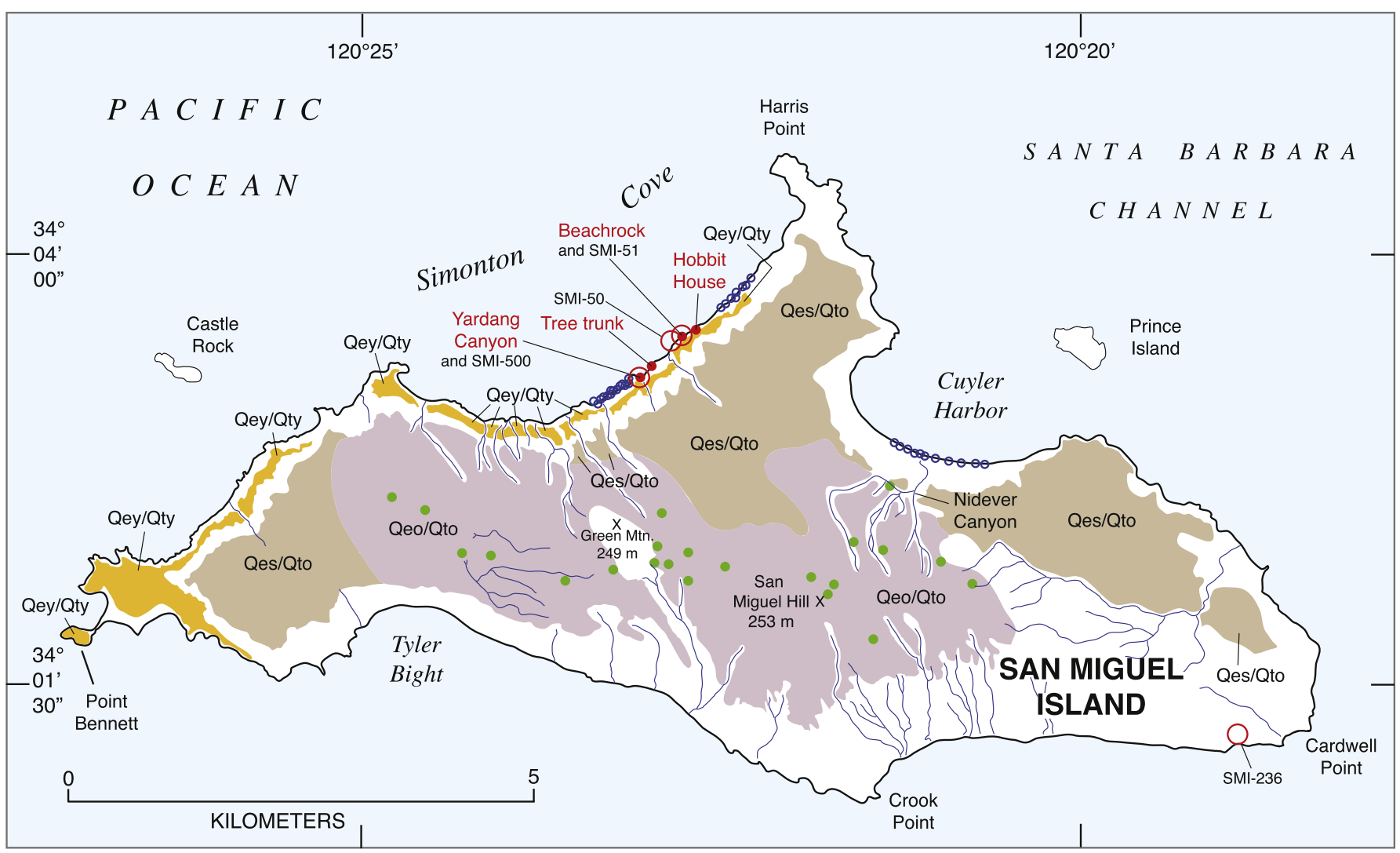

Qey/Qty Historic or Holocene (Qeh) and/or late Quaternary aeolianite or aeolian sand (Qey) over last interglacial marine terrace complex deposits (Qty)

Qes/Qto Historic or Holocene (Qeh) and/or undifferentiated Quaternary aeolianite or aeolian sand (Qes) over pre-last interglacial marine terrace deposits (Qto)

Qeo/Qto Historic or Holocene (Qeh) and/or undifferentiated Quaternary aeolianite or aeolian sand (Qes) over pre-late Quaternary aeolianite (Qeo) with Green Mountain soil in its upper part, all overlying pre-last interglacial marine terrace deposits (Qto)

$\begin{array}{cccc}\begin{array}{c}\text { Green Mountain } \\ \text { soil observed }\end{array} & \begin{array}{c}\text { Eolian sand/eolianite } \\ \text { section studied }\end{array} & \begin{array}{c}\text { Modern beach } \\ \text { sand collected }\end{array} & \begin{array}{c}\bigcirc \text { SMI-50 } \\ \text { Marine terrace } \\ \text { fossil locality }\end{array}\end{array}$

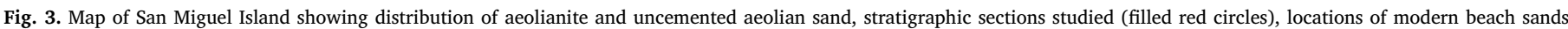

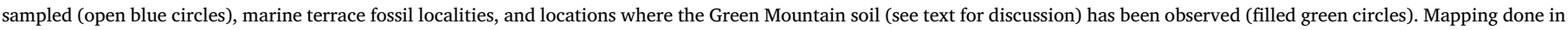

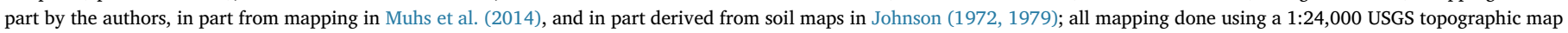
base. (For interpretation of the references to color in this figure legend, the reader is referred to the web version of this article.)

1979) were used in part for some of the mapping, particularly on San Miguel Island, and this approach was extended to new mapping on Santa Rosa Island. The basis of this approach is that degree of soil development is a function of deposit age (Birkeland 1999). We also used stratigraphic relations of aeolian sands with underlying marine terrace deposits to differentiate some units. As mentioned above, overgrazing during the 19th century and early part of the 20th century denuded San Miguel Island of much of its vegetation and brought about widespread reactivation of previously stabilized aeolian sand (Johnson 1980). Thus, by the late 1920s, much of the island was covered by historically reactivated aeolian sand. While much of this active dune sand from the early part of the 20th century has now been stabilized (Zellman 2014), detailed delineations of different ages of Pleistocene and prehistoric Holocene sand are simply not possible for much of the island because the landscape has been masked by historically active sand.

\subsection{Carbonate mineral content and mineralogy}

Mineralogy of selected samples of aeolianites and beach sands was determined by X-ray diffractometry (XRD) on pulverized, randommount samples using copper radiation. For semiquantitative comparisons of relative abundances of minerals in aeolian sand, we measured peak heights of quartz (20.8 ${ }^{\circ}$ two-theta), aragonite (26.2 ${ }^{\circ}$ two-theta), Kfeldspar (27.4 $4^{\circ}$ two-theta), plagioclase (27.8 ${ }^{\circ}$ two-theta), and calcite (29.4 $4^{\circ}$ two-theta). Ternary diagrams presented here were generated by using peak heights of these minerals on XRD diagrams; thus, we stress that such diagrams provide only relative abundances of these mineral species. Total inorganic carbon concentrations of aeolianites and beach sands were measured using a rapid and precise method that utilizes automated coulometric titration (Engleman et al. 1985). Although the method does not distinguish calcite and aragonite, it provides very precise estimates of total carbonate content. For one of the sections studied, Coati Point on Santa Rosa Island, carbonate content was measured using a Chittick instrument (Dreimanis, 1962).

\subsection{Radiocarbon dating}

Charcoal (charred vascular plants), calcite rhizoliths, terrestrial gastropod shells (Helminthoglypta ayresiana), and humic acids extracted from organic matter were analyzed for radiocarbon $\left({ }^{14} \mathrm{C}\right)$ to establish the chronologic framework at a number of stratigraphic sections. Charcoal samples were subjected to a standard acid-base-acid treatment and then combusted in a sealed quartz tube in the presence of cupric oxide and silver. The resulting $\mathrm{CO}_{2}$ was split into two aliquots. One 


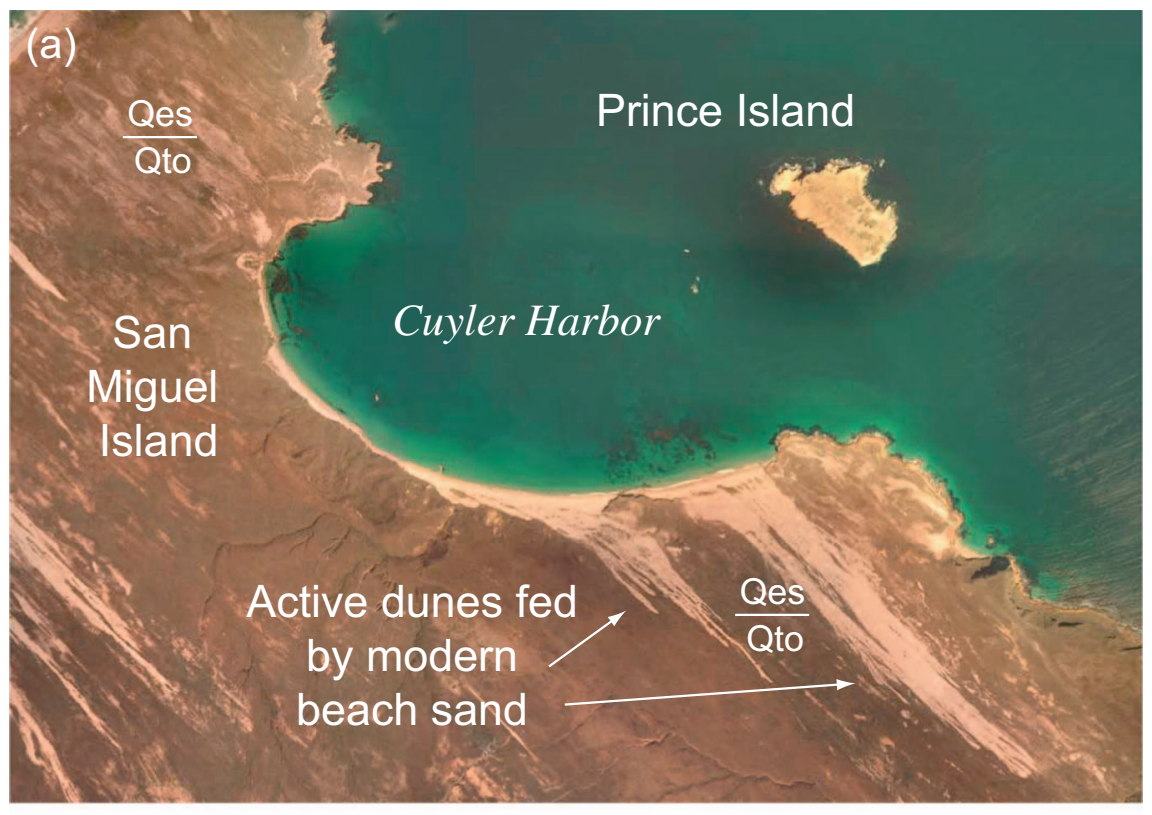

Fig. 4. (a) True-color aerial photograph (acquired 2002) of the Cuyler Harbor area of San Miguel Island (see Fig. 3 for location) showing active dunes being fed by sediment from the modern beach. (b) Ground photograph of the dunes shown in (a).

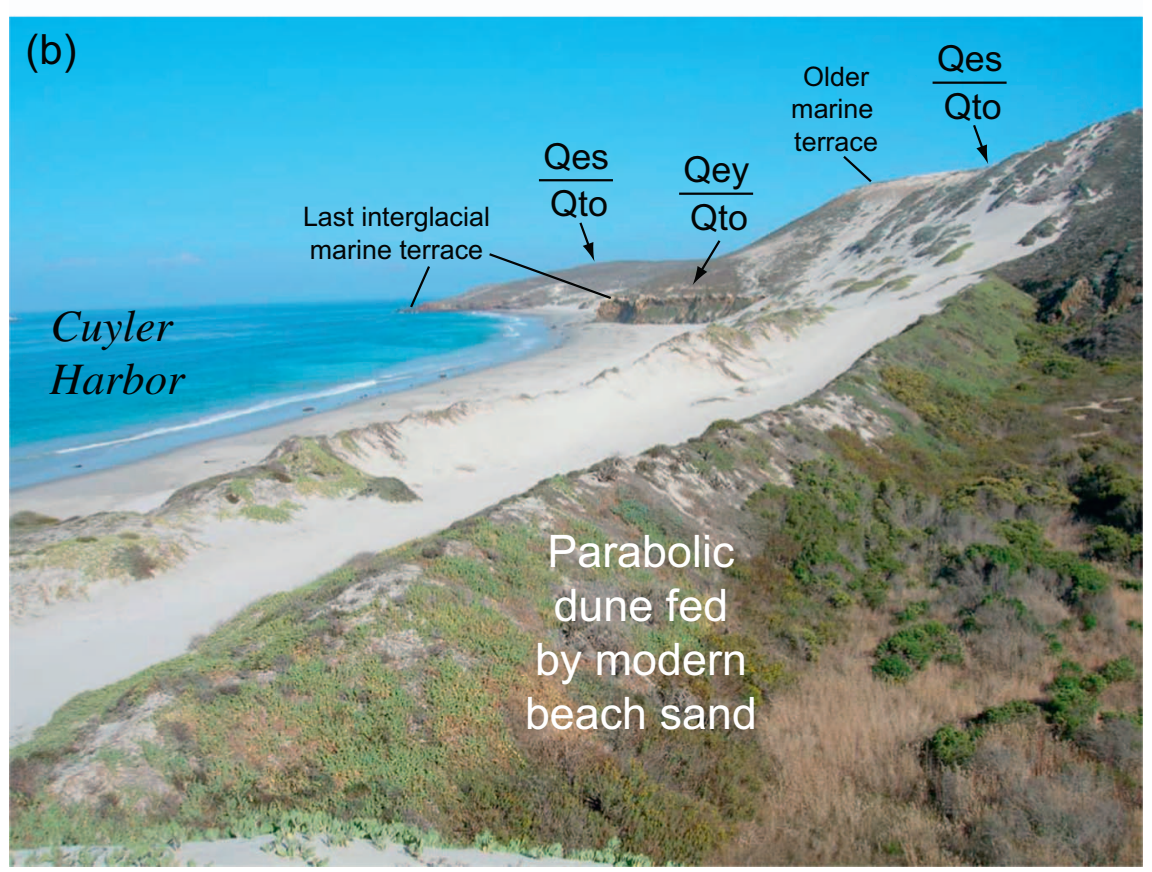

aliquot was converted to graphite using an iron catalyst and a standard hydrogen reduction process and submitted to the Center for Accelerator Mass Spectrometry (CAMS) at Lawrence Livermore National Laboratory for ${ }^{14} \mathrm{C}$ analysis. The second aliquot was submitted to the University of California, Davis Stable Isotope Laboratory for $\delta^{13} \mathrm{C}$ analysis in order to correct the measured ${ }^{14} \mathrm{C}$ activity for isotopic fractionation. At some localities, there was insufficient charcoal for radiocarbon dating but a sufficient amount of soil organic matter for extraction of humic acids. At these sites, and at a few sites where there was charcoal and soil organic matter, both materials were analyzed for radiocarbon. Humic acids were extracted for radiocarbon ages following methods outlined by McGeehin et al. (2001).

Calcite rhizoliths collected for radiocarbon dating were cleaned mechanically of all adhering detrital shell carbonate grains, after which only the interior, entirely secondary, low-Mg calcite portion of the rhizolith remained. As a check on the cleaning procedure, each cleaned rhizolith was examined under magnification and then pulverized.
Pulverized splits were X-rayed to ensure that the cleaned portions of the rhizoliths contained only calcite, with no detrital shell fragments remaining (which would be indicated by the presence of aragonite and/or high-Mg calcite). As a further check on secondary calcite purity, a separate aliquot derived from each rhizolith was submitted to the University of California, Davis Stable Isotope Laboratory for $\delta^{13} \mathrm{C}$ analysis. This procedure was conducted both for corrections of the radiocarbon ages (as described above), and also for assessment of carbonate origin. Calcites that formed entirely as secondary, pedogenic accumulations in rhizoliths from detrital marine skeletal carbonates should have $\delta^{13} \mathrm{C}$ values that fall within the range of secondary, pedogenic carbonates reported in soils ( -9 to $-5 \%$; see Quade et al. 1989), which is the same range of these values in the atmosphere. In contrast, modern or Holocene bivalve and gastropod shells, two of the major components of the aeolianite sands from which the rhizoliths formed, collected from exposed, open-ocean reaches of coastal southern California, have $\delta^{13} \mathrm{C}$ values ranging from 0.0 to $+2.8 \%$ (e.g., Muhs and 
Kyser 1987; Kennett et al. 1997; Eerkens et al. 2005, 2010). If there were insufficient cleaning of rhizoliths, and some detrital skeletal grains were retained, the $\delta^{13} \mathrm{C}$ values would fall outside of the range of pedogenic carbonates. Thus, an important criterion for acceptance of rhizolith radiocarbon ages is that $\delta^{13} \mathrm{C}$ values of the rhizoliths fall within the range of typical pedogenic carbonates and outside the range of modern carbonate marine organisms.

Recent studies have shown that small terrestrial gastropods have considerable potential as suitable materials for radiocarbon dating (Pigati et al. 2010, 2013). In this study, we used the land snail Helminthoglypta ayresiana, which is common on San Miguel Island today and in the fossil record. Gastropod shells were placed in a beaker of ASTM Type 1, 18.2 M $\Omega$ (ultrapure) water and subjected to an ultrasonic bath until the shells were visibly clean. In most cases, shells were treated with $\mathrm{H}_{2} \mathrm{O}_{2}$ and then selectively dissolved or etched briefly with dilute $\mathrm{HCl}$ to remove secondary carbonate (dust) from primary shell material. The etched shells were washed repeatedly in ultrapure water and dried in an oven overnight at $70{ }^{\circ} \mathrm{C}$. The shells were then broken and examined under magnification to ensure that the interior whorls were free of secondary carbonate and detritus. Clean shell carbonate was converted to $\mathrm{CO}_{2}$ using ACS reagent grade $85 \% \mathrm{H}_{3} \mathrm{PO}_{4}$ under vacuum at $50{ }^{\circ} \mathrm{C}$ until the reaction was visibly complete $(\sim 1 \mathrm{~h})$. The resulting $\mathrm{CO}_{2}$ was processed in the same manner as the charcoal samples.

Finally, the ${ }^{14} \mathrm{C}$ ages for the gastropod shells, charcoal, rhizoliths, and humic acids were calibrated using the IntCal13 dataset and the CALIB 7.1.html calibration program (Stuiver and Reimer 1993; Reimer et al. 2013). Ages are presented as the midpoint of the 2-sigma calibrated age range in calibrated ${ }^{14} \mathrm{C}$ years $\mathrm{BP}(\mathrm{ka}=$ thousands of years; $\mathrm{BP}=$ Before Present; 0 yr BP $=1950 \mathrm{CE}$ ). Uncertainties are calculated as the difference between the midpoint and the minimum and maximum limits of the calibrated age range. All values are rounded to the nearest 10 years.

\subsection{Luminescence dating}

Luminescence dating, including optically stimulated luminescence (OSL) and infrared stimulated luminescence (IRSL), is a commonly applied method for geochronology of aeolian samples (see review in Singhvi and Porat 2008). Samples were prepared and measured at the Luminescence Laboratory of the Geological Survey of Israel, Jerusalem. Sample preparation for quartz follows Faershtein et al. (2016), which includes wet sieving to isolate grain fractions of $125-150 \mu \mathrm{m}$, followed by immersion in $8 \% \mathrm{HCl}$ to remove carbonates. After rinsing and drying, heavy minerals and most feldspars were separated from the quartz with a Frantz LB-1 magnetic separator using a high (1.4 A) current on the magnet (Porat 2006). Subsequently, the quartz-rich nonmagnetic fraction was etched with concentrated (40\%) HF for 40 min to etch grain rinds affected by alpha particles and dissolve any remaining feldspars, followed by a $16 \% \mathrm{HCl}$ treatment to remove any precipitated fluorides (Porat et al., 2015). Potassium feldspars (KF) were extracted from the magnetic fraction by heavy liquid density separation using sodium polytungstate with a density of $2.58 \mathrm{~g} / \mathrm{cm}^{3}$ and were not etched by HF.

\subsubsection{Quartz}

Approximately 150 grains were mounted on $10 \mathrm{~mm}$ aluminum discs with $2 \mathrm{~mm}$ masks using silicon (oil) spray as an adhesive. Equivalent dose (De) determinations used a modified single aliquot regenerativedose (SAR) protocol (Murray and Wintle 2003) that included a cleaning step of heating to $280{ }^{\circ} \mathrm{C}$ for $100 \mathrm{~s}$ at the end of each measurement cycle. The protocol started with measuring the natural signal, followed by a zero dose point to test for thermal transfer, three beta dose points, a second zero dose point, a repeated dose (for recycling ratio) and a second repeated dose after infrared (IR) bleaching (IR depletion ratio). Measurements were carried out on a DA-12 or DA-20 TL/OSL Risø Readers equipped with blue LEDs and IR diodes. Irradiation was by a calibrated ${ }^{90} \mathrm{Sr}$ beta source and the luminescence signal was detected through $7 \mathrm{~mm} \mathrm{U}-340$ filters. Dose recovery tests over a range of preheats showed that the best recovery ratio (1.03) is obtained when using a pre-heat time of $10 \mathrm{~s}$ at $240^{\circ} \mathrm{C}$, a test dose of $\sim 9 \mathrm{~Gy}$ and a test dose preheat of $5 \mathrm{~s}$ at $220^{\circ} \mathrm{C}$; these measurement conditions were used for all quartz fractions.

Age calculations relied on a De averaged from 13 to 19 measurements (aliquots) per sample. Average De values and errors for each sample were calculated using the central age model (CAM; Gailbraith and Roberts 2012). A measure of scatter is over-dispersion (O-D), a parameter which represents the scatter in the De values beyond that which is caused by the analytical errors of single values (Gailbraith and Roberts 2012). Low O-D values indicate more uniform bleaching at the time of deposition and higher reliability. The high scatter is generally assumed to result from the presence of grains with varying degrees of exposure to sunlight during transport, from post-depositional introduction of grains from the surface into the section or, for quartz grains, from exposure to varying $\beta$ doses from nearby alkali feldspars or zircon grains (Mayya et al. 2006). The youngest grains are the best bleached and in an aeolian environment best represent the time of deposition.

Four samples with high O-D were selected for single grain (SG) measurements. Hole size in the standard single grain disc is $300 \mu \mathrm{m}$ whereas quartz grain size was $125-150 \mu \mathrm{m}$; thus, it is possible that more than one grain was present in some holes. Between 400 and 500 single grains were measured for each sample using green laser stimulation and the same protocol as for the multi-grain measurements, and were screened for further data processing using the criteria suggested by Porat et al. (2009): (a) signal intensity at least 3 times that of the background; (b) error on the De smaller than 40\%; (c) error on the test dose smaller than $30 \%$; and (d) recycling ratio within $20 \%$ of unity. In addition, zero-age grains, i.e., those with no natural signal but which responded to laboratory irradiation, and grains whose natural signal could not be recovered were rejected.

The De values and errors were calculated using the finite mixture model (FMM; Gailbraith and Roberts 2012) which assumes that the grain distribution consists of a number of normally distributed components (Roberts et al. 2000). The youngest component larger than $10 \%$ of all grains was selected to represent the best-bleached component (Rodnight et al. 2006), but the most common component is also given in Table 2.

\subsubsection{Potassium feldspar}

Potassium feldspars (KF) were measured either at the Geological Survey of Israel in the same TL/OSL readers as the quartz, or at Ris $\varnothing$ DTU, Denmark. Grains were mounted on aluminum discs or stainless steel cups using a 2-mm mask and silicon spray as an adhesive, and the De values were measured on 6-9 aliquots per sample using the protocol of Buylaert et al. (2008). Stimulation was carried out with IR diodes, detection was through a combination of BG-39 and 7-59 filter pack, and both the $\mathrm{IR}_{50}$ and the pIR-IR 290 signals were used for De calculations using the CAM.

Anomalous fading was measured and g-values calculated following Buylaert et al. (2009). G-values per decade of $0.7 \pm 1.1$ and $2.8 \pm 1.1$ were obtained for the pIR-IR ${ }_{290}$ and the $\mathrm{IR}_{50}$ signals, respectively, showing that the pIR-IR 290 does not fade whereas the $\operatorname{IR}_{50}$ fades in a minor way. The $\mathrm{IR}_{50}$ ages were corrected for fading, and the differences between the ages obtained by the two signals are discussed below.

\subsubsection{Dose rates}

Dose rates were calculated from the concentrations of the radioactive elements (K, Th and $\mathrm{U}$ ) in the sediments, measured by inductively coupled plasma mass spectrometry (U and Th) or optical emission spectroscopy (K), with relative uncertainties of $5 \%, 10 \%$ and $3 \%$, respectively. The concentrations were converted into alpha, beta 
and gamma dose rates using the factors presented by Nambi and Aitken (1986). K-content of the KF was estimated at $12 \pm 0.5 \%$, a value similar to that suggested by Huntley and Baril (1997), and an alpha efficiency (a-value) of $0.09 \pm 0.02$ was used in the dose rate calculations (Balescu et al. 2007). Table 2 lists the samples, field and laboratory data, luminescence ages, and errors (one sigma).

\subsection{Amino acid geochronology}

Most aeolianite deposits on the northern Channel Islands are underlain by fossiliferous marine terrace deposits. Dating of such deposits, therefore, provides a maximum-limiting age for the overlying aeolian sediments. Radiocarbon and uranium-series methods provide numerical ages of marine terrace fossils, but most marine terrace deposits in southern California are beyond the range of radiocarbon dating and uranium-series dating requires corals. Thus, for marine deposits beyond radiocarbon dating range that also lack corals, amino acid geochronology provides an appropriate method for correlation to dated deposits elsewhere. Wehmiller (1982, 1992, 2013a, 2013b), Wehmiller and Miller (2000), and Miller and Clarke (2007) review the method in detail.

For amino acid geochronology, the present study utilizes the common gastropod Callianax biplicata (formerly Olivella biplicata) and the intertidal bivalve Epilucina californica, the only two species found on undated marine terrace deposits of northern San Miguel Island. Because Callianax has not been utilized previously for amino acid geochronology, we conducted feasibility tests on nearby San Nicolas Island, where there is an extensive flight of emergent marine terraces and Callianax is abundant. Relative abundances (using peak areas or peak heights on chromatograms) of $\mathrm{D}$ and $\mathrm{L}$ enantiomers of the amino acids valine and glutamic acid were measured in fossil specimens of these genera, using reverse-phase liquid chromatography (Kaufman and Manley 1998) at the Amino Acid Geochronology Laboratory at the University of Colorado, Boulder. Interlaboratory comparisons of this facility with others can be found in Wehmiller (2013c). D/L values for valine and glutamic acid were measured using both peak areas and peak heights. Comparison of D/L values computed by both peak heights and peak areas shows no significant differences (Supplementary Data Table 1). Somewhat better run-to-run agreement was achieved with peak-area ratios, however; thus, these values were used in figures and interpretations.

Amino acid racemization is a temperature-dependent process, with racemization occurring at lower rates in cooler climates. In comparing amino acid ratios of fossil mollusks from the Channel Islands, D/L values were measured in newly collected fossil Callianax biplicata specimens from other, dated marine terrace localities. These collections were made from localities along a roughly north-south temperature gradient from central California to southern California, identical to those used for other species by Muhs et al. (2014). These localities host deposits containing corals that have been dated independently by U-series methods to $\sim 80 \mathrm{ka}$ (equivalent to marine isotope stage [MIS] 5.1, using terminology of Martinson et al. 1987) and either $\sim 120 \mathrm{ka}$ (MIS 5.5) or a mix of $\sim 100 \mathrm{ka}$ (MIS 5.3) and $\sim 120 \mathrm{ka}$ (MIS 5.5) ages, based on studies by Muhs et al. (1994, 2002a, 2006, 2012b, 2014, 2015). Under favorable conditions, D/L values in shells from deposits of the same age form an isochron line or band with northward-decreasing values. Shells of younger deposits should yield a parallel or subparallel isochron band of $\mathrm{D} / \mathrm{L}$ values below that defined by an older suite of shells. Thus, D/L values in shells of a deposit of unknown age can be plotted on these latitudinal arrays for purposes of correlation.

\section{Aeolianite on San Miguel Island}

\subsection{Distribution of aeolian sand and aeolianite on San Miguel Island}

Three aeolian sand units were defined and mapped on San Miguel
Island, identified by stratigraphic relations and relative age, the latter by using degree of soil development. The oldest aeolian sands (Qeo) cover much of the interior of San Miguel Island (Fig. 3). These deposits are found at some of the highest elevations on the island and even occur near the summit of San Miguel Hill (253 m above sea level). Beneath historically active sand (Qeh) and where they occur at the surface, these aeolian sands are characterized by a well-developed soil that Johnson (1972, 1979) called the "Green Mountain soil." This soil has a wellexpressed $\mathrm{A} / \mathrm{E} / \mathrm{Bt} / \mathrm{Bk} / \mathrm{C}$ profile, where not eroded, and pedon thicknesses can range up to $3 \mathrm{~m}$ or more. Commonly, the lower A horizon and parts of the E and upper Bt horizons host Fe-rich, pea-sized, spherical pisoliths (also called pisolites; see Fig. 9c and d in Muhs 2014 for examples from San Miguel Island). The Bt horizons of the soils have well-developed clay films on prismatic or columnar peds and Bk horizons can be stage IV laminar K horizons (using the terminology of Gile et al. 1966). Importantly, this unit does not overlie the low-elevation marine terrace (Qty) that rims much of the island and has been dated to $\sim 120,000 \mathrm{yr}$ by Muhs et al. (2014), but it does overlie all higher terraces (Qto) that characterize older landscapes on San Miguel Island. Thus, the oldest aeolian sand unit on the island is likely older than $\sim 120,000 \mathrm{yr}$.

The second-oldest unit (Qes) consists of aeolian sand and aeolianite, also overlain by historically active sand (Qeh). These deposits overlie pre-last-interglacial marine terraces (Qto), but lack Green Mountain soil profiles. Because of the historical aeolian sand cover, good exposures of these sands are rare, but where they occur, they usually display wellcemented aeolianite, with their upper parts characterized by carbonate rhizoliths, laminar calcretes (Bk or $\mathrm{K}$ horizons), and sometimes strong brown to yellowish-brown Bt horizons. Importantly, soils in this unit lack the pisoliths that are characteristic of soils developed in unit Qeo. Deposits of unit Qes are well exposed south of Harris Point, around Cuyler Harbor, in Nidever Canyon, in the higher parts of sea cliffs of Simonton Cove, and northwest of Tyler Bight (Fig. 3). Similar to unit Qeo, unit Qes does not overlie the low-elevation marine terraces (Qty) but does overlie all higher terraces (Qto). Thus, at least some parts of this unit could date to more than $\sim 120,000$ years, but it is younger than Qeo.

The youngest Pleistocene aeolianite unit (Qey) consists of aeolian sands that overlie marine terraces that date to the last interglacial period $(\sim 120,000 \mathrm{yr}$ to $\sim 80,000 \mathrm{yr}$; Qty). The unit is best exposed along Simonton Cove, where most of the present study areas are located, but it is also found along the northern coast of the island between Simonton Cove and Point Bennett (Fig. 3). The aeolianites in this unit consist of at least two and often three subunits, with a combined thickness of up to $\sim 20 \mathrm{~m}$. Holocene aeolian sand, mostly uncemented, overlies the Qey unit and is extensive on San Miguel Island (Erlandson et al. 2005).

As noted above, the Qes unit is positioned on terraces older than $\sim 120,000 \mathrm{yr}$ whereas the Qey unit is found on the $\sim 120,000 \mathrm{yr}$ and $\sim 80,000 \mathrm{yr}$ terraces. However, the similar degree of development (reddish brown Bt horizons underlain by laminar calcrete Bk horizons) in the surface soils of the Qes unit and the Simonton soils of the lower Qey unit would permit an interpretation that the two deposits are of similar age. Thus, it is possible that Qes is simply an inland facies of the lower part of Qey.

\subsection{Aeolianite stratigraphy of study localities on San Miguel Island}

The best exposures of the Qey aeolianites on San Miguel Island are found along the sea cliffs fronting Simonton Cove (Fig. 3). Rarely does any single cliff section expose all of the units we have identified, but as is often the case in Quaternary stratigraphy, lateral correlations can be made between exposures based on sediment characteristics and distinctive aspects of the paleosols separating units.

The westernmost locality we studied is at Yardang canyon, the main Simonton Cove section studied by Johnson (1972, 1977, 1980). The sea 

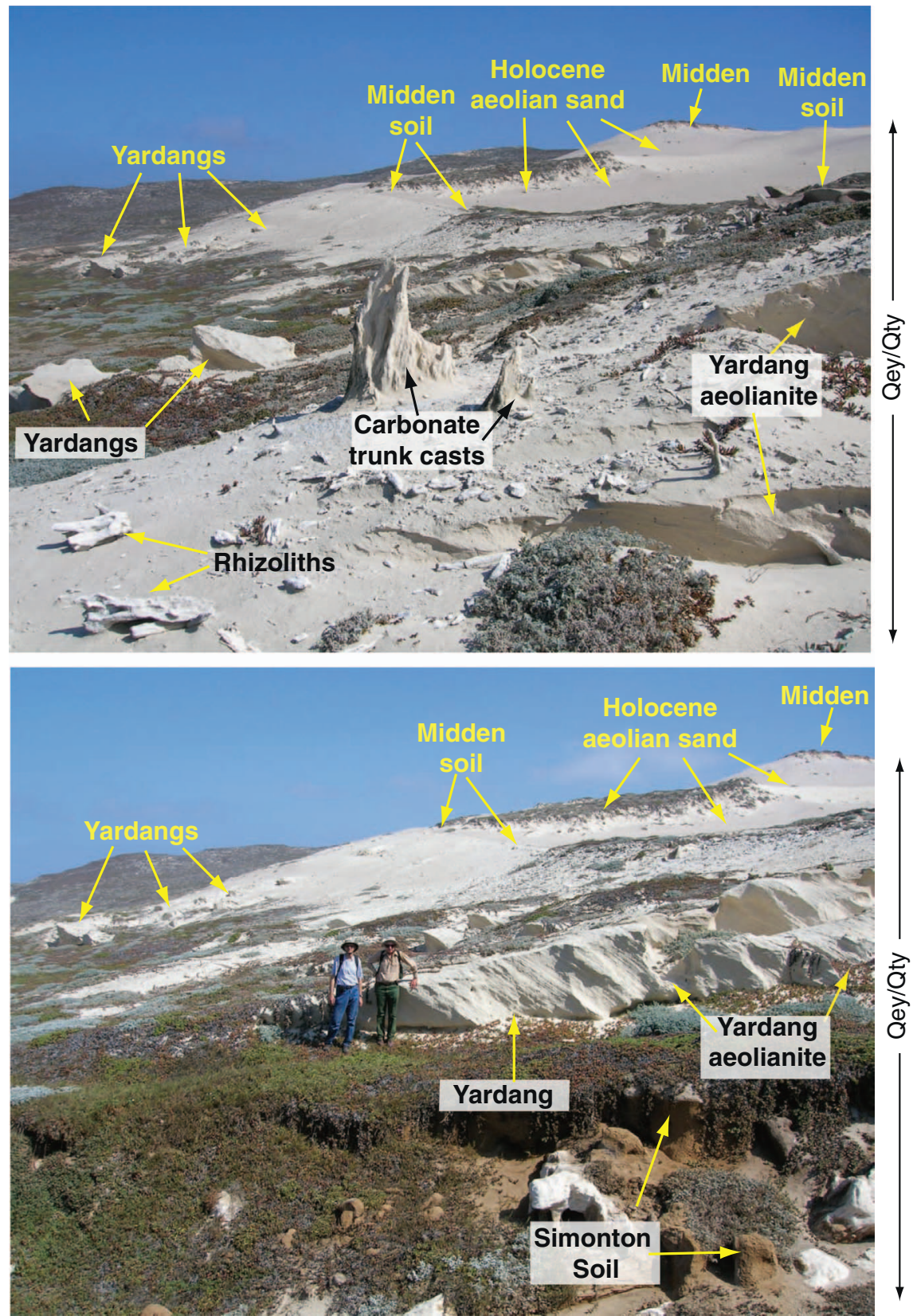

Fig. 5. Photographs showing the stratigraphy of the "Yardang canyon" section on San Miguel Island (see Fig. 3 for location). Note carbonate trunk casts in (a) and geologists for scale in (b). Photographs by D.R. Muhs. cliff here exposes Tertiary bedrock, a marine terrace with a shoreline angle at $\sim 3.5 \mathrm{~m}$ above sea level and another marine terrace with a wave-cut bench whose outer edge is $\sim 10 \mathrm{~m}$ above sea level. The higher of these two marine terraces is overlain by $2-3 \mathrm{~m}$ of light gray (10YR 7/ 2 , dry) aeolianite, and capped by a paleosol with a strong brown (7.5YR $5 / 6$, dry) to yellowish-brown (10YR $5 / 6$, dry) Bt horizon that we interpret to be the equivalent of Johnson's $(1972,1977,1980)$ Simonton soil (Fig. 5). About $20 \mathrm{~m}$ landward, what also appears to be the Simonton soil is exposed in canyon walls and is overlain by $\sim 7 \mathrm{~m}$ of younger, light-gray (10YR 7/2, dry) to very pale brown (10YR $8 / 2$, dry) aeolianite. A short distance to the east, this aeolianite ranges up to $\sim 16 \mathrm{~m}$ thick. This unit is equivalent to what Johnson (1972, 1977, 1980) called the Yardang aeolianite. High-angle crossbeds in this aeolianite dip $29^{\circ}$ to $35^{\circ}$ landward, to the south or south-southeast, implying paleowinds from the north or northwest (Fig. 5b). The sand within the Yardang aeolianite is well enough cemented that the sediment body has been secondarily eroded into yardangs (Fig. 5a, b), from which Johnson (1972) coined the informal name for the canyon and the aeolianite unit itself. Rhizoliths and calcified tree trunks are found in the upper part of the cross-bedded Yardang aeolianite. The Yardang aeolianite is capped by what Johnson $(1972,1977,1980)$ called the Midden soil, so called because midden deposits can be found in its uppermost horizons. The Midden soil is an over-thickened, cumulic A horizon with dark, grayish-brown (10YR 4/2, dry) colors in its upper part and slightly lighter grayish-brown (10YR 5/2, dry) colors in its lower part. The Midden soil is in turn overlain by Holocene aeolian sand (Fig. 5a).

A similar stratigraphy is exposed east of Yardang canyon at what we call the "Tree Trunk" section (Fig. 6a, b; see Fig. 3 for location). Here, a thin aeolianite, with the Simonton soil developed in its upper part, is exposed in the sea cliff, overlying a marine terrace whose outer edge is $\sim 11 \mathrm{~m}$ above sea level (Fig. 6a). Overlying the Simonton soil is the Yardang aeolianite. This deposit crops out in small patches and displays high-angle cross-bedding, dipping landward. Although the Yardang aeolianite here is thinner than to the east, the Midden soil that is developed in it is thicker, up to $\sim 3 \mathrm{~m}$ (Fig. 6b). At this locality, the 


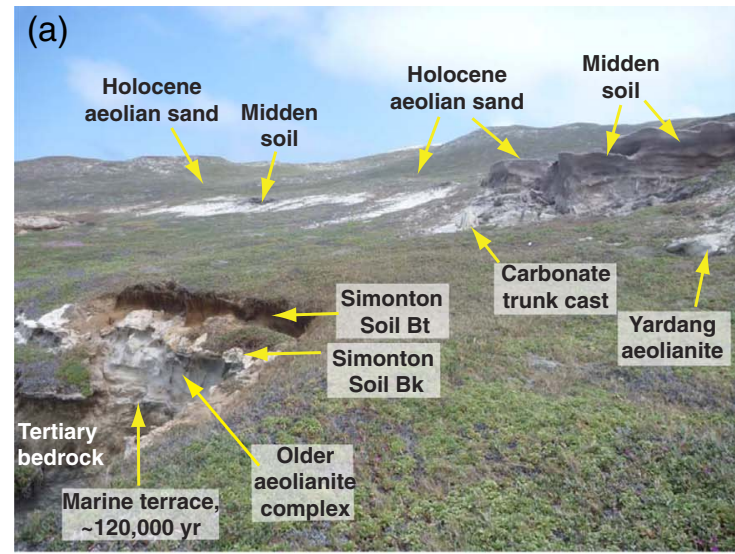

(b)

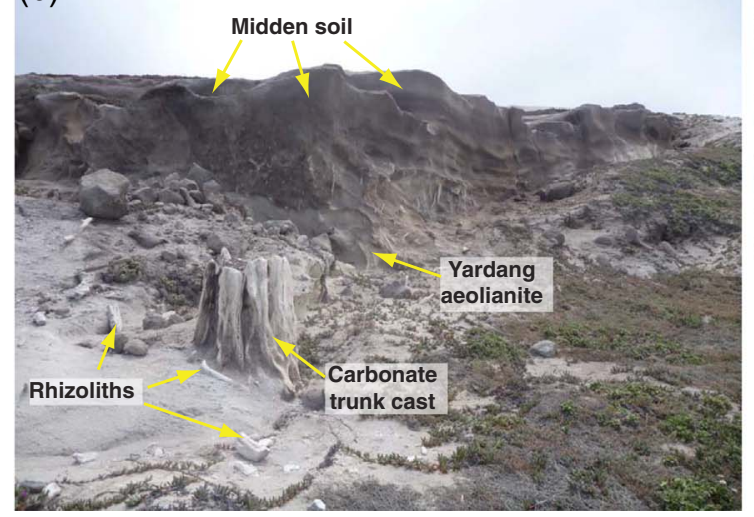

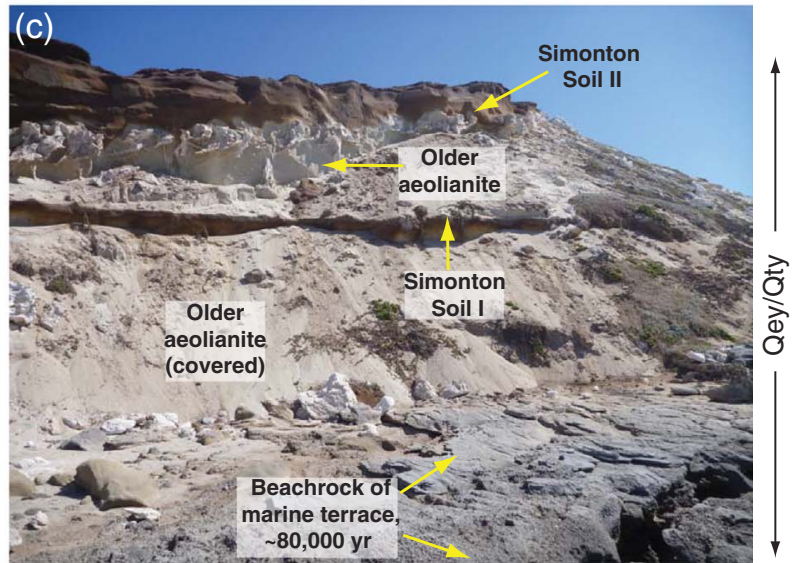

Fig. 6. Photographs [(a) and (b)] showing the stratigraphy of the "Tree Trunk" section and (c) "Beachrock" section on San Miguel Island (see Fig. 3 for locations). Photographs by D.R. Muhs.

Midden soil appears to have formed as an accretionary soil, or pedocomplex, with thin aeolian sand deposits laid down successively, punctuated by stabilization by vegetation and soil formation. Rhizoliths are common in the lower part of the Midden soil and include a calcified tree trunk (Fig. 6b).

The most complete exposure we have found is what we refer to as the "Hobbit House" section because of the lower part's uncanny resemblance to such structures in the beloved stories about J.R.R. Tolkien's Hobbit characters (Fig. 7a, b). Here, as at Yardang canyon, two marine terraces are exposed, both cut on Tertiary bedrock. The outer edge of the higher marine terrace is found at $\sim 5.5 \mathrm{~m}$ above sea level and the shoreline angle of the lower terrace is found at $\sim 3.5 \mathrm{~m}$ above sea level, identical to the low terrace at Yardang canyon. Both terraces are capped by three Pleistocene aeolianite units, the lowest of which is thickest on the 3.5-m-high marine terrace (Fig. 7b). Bedding is not apparent in the two lower aeolianites. Both are capped by paleosols with strong brown to yellowish-brown, clay-rich Bt horizons. The uppermost of these also has a distinctive calcrete Bk horizon, and carbonate rhizoliths are found below the Bt and/or Bk horizons in these paleosols. We refer to the lower paleosol as "Simonton soil I" and the upper one as "Simonton soil II." Above these two paleosols, there is a much thicker aeolianite package, better cemented than the lower units, and with excellent preservation of primary bedding (Figs. 7a, 8a, b) that we interpret to be the Yardang aeolianite. The Yardang aeolianite here is as much as $17 \mathrm{~m}$ thick and consists almost entirely of high-angle foreset beds. These beds have high-angle $\left(26^{\circ}\right.$ to $\left.35^{\circ}\right)$, landward dips to the east or east-southeast, indicating paleowinds from the west or westnorthwest. The uppermost part of the Yardang aeolianite has the Midden soil developed in it, with a thick, dark brown, well-preserved A horizon underlain by a Bk horizon, in turn underlain by carbonate rhizoliths. Holocene aeolian sand, mostly with horizontal bedding, overlies the Midden soil and is as much as $\sim 30 \mathrm{~m}$ thick at the Hobbit House section. We observed four midden deposits within the Holocene aeolian package.

Finally, what we call the "Beachrock" section, just west of the Hobbit House section (Fig. 3), lacks the distinctive Yardang aeolianite, but has more details of the lower part of the stratigraphy. Here, an aeolian sequence overlies a marine terrace with a shoreline angle elevation that is $\sim 3.5 \mathrm{~m}$ above sea level (Fig. $6 \mathrm{c}$ ). Unlike what is seen at the Hobbit House section, deposits of the terrace at this locality are well cemented into beachrock, described in detail by Johnson (1969). The two aeolianites found above the beachrock of the marine terrace do not show distinctive bedding and have laterally variable thicknesses, ranging from less than $\sim 1 \mathrm{~m}$ to as much as $\sim 6 \mathrm{~m}$. At the Beachrock section, these aeolianites are capped by distinctive soils with strong brown to yellowish-brown, clay-rich Bt horizons underlain by laminar, calcrete Bk horizons and rhizoliths. Based on the similar soil morphology, we hypothesize that these paleosols may correspond to Simonton soil I and Simonton soil II at the Hobbit House section.

\subsection{Mineralogy of San Miguel Island aeolianites and beach sand}

Aeolianites and non-cemented aeolian sand on San Miguel Island have a relatively simple mineralogy. They are composed primarily of quartz, K-feldspar, plagioclase, calcite and aragonite. We examined sand grains from Pleistocene aeolianites on San Miguel Island microscopically. In addition to the silicate minerals (quartz, K-feldspar, and plagioclase) and rock fragments, marine organisms make up a significant proportion of the grain population. These grains consist of angular, sand-sized fragments of gastropods, bivalves, echinoid (sea urchin) spines, foraminifera, possible barnacles, sponge spicules, and possibly bryozoans. These observations agree with thin section studies 
(a)

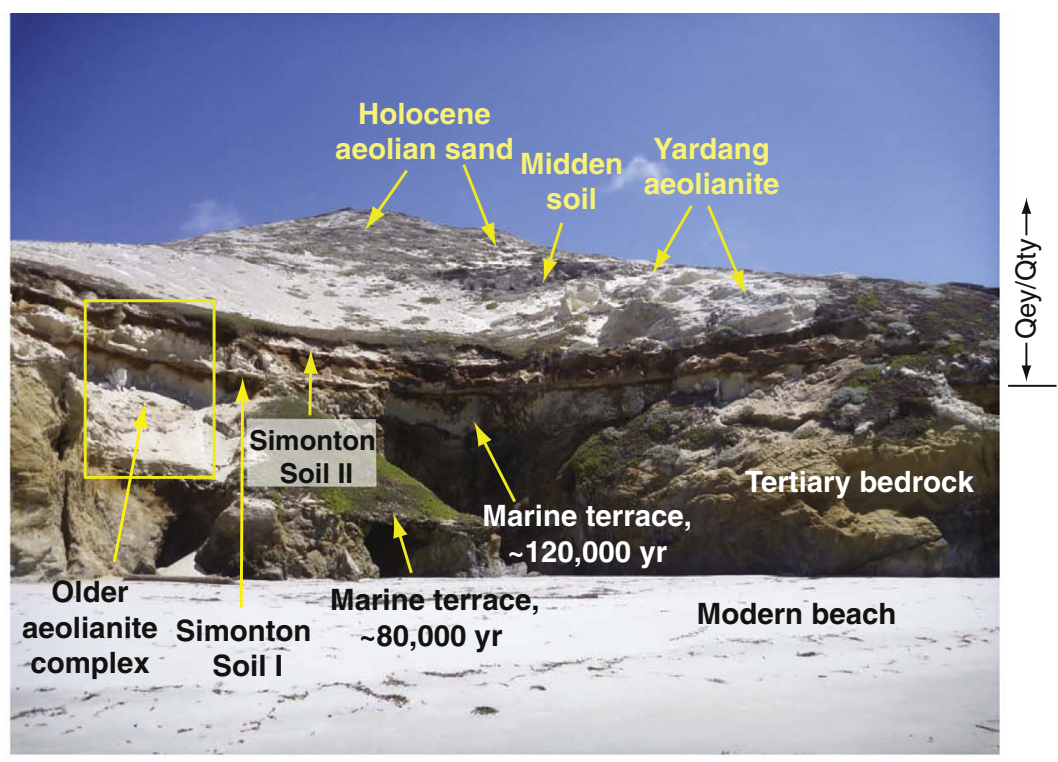

(b)

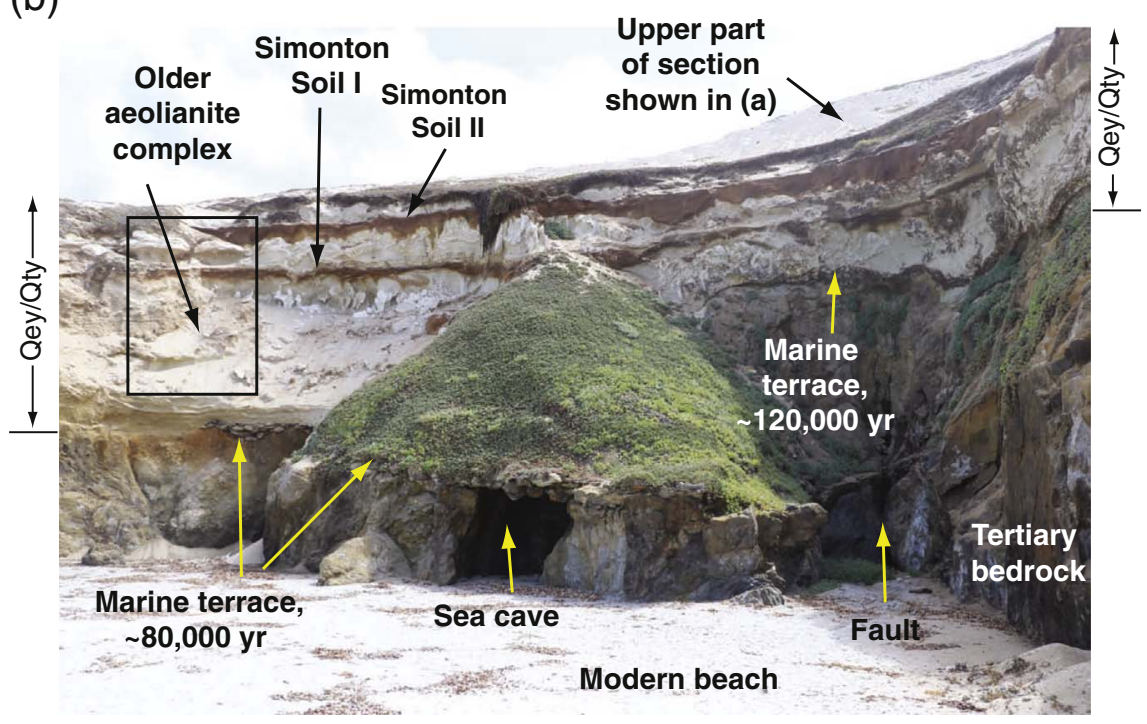

Fig. 7. Photographs of the lower part of the "Hobbit House" section on San Miguel Island showing (a) relationship of units to the upper part of the section (shown in Fig. 8) and (b) relationship of units to the $\sim 80,000$ and $\sim 120,000$-yr-old marine terraces.

Photographs by D.R. Muhs. conducted by Johnson (1972).

Mainland dunes, collected at Guadalupe, Lompoc, and Port Hueneme, California have a very different mineralogy than aeolian sands on San Miguel Island. All three of these dune fields have quartz, plagioclase, and K-feldspar, but dunes at Port Hueneme and Lompoc contain no detectable aragonite and only very small amounts of calcite. Dunes at Guadalupe contain no calcite or aragonite that could be detected by XRD. Results are similar to what Emery (1960) reported for mainland California dunes at El Segundo, near Los Angeles, where carbonate contents for 40 aeolian sands averaged only $1 \%$. Thus, California mainland dunes have much lower calcite contents relative to quartz and plagioclase than both Pleistocene aeolianites and modern dunes on both San Miguel Island and San Nicolas Island (Fig. 9). The Yardang aeolianite at the Hobbit House section, at depths between 200 and $1700 \mathrm{~cm}$, has total $\mathrm{CaCO}_{3}$ contents (aragonite and calcite combined) ranging from $\sim 60 \%$ to $\sim 90 \%$ (Fig. 10). Modern beach sand on San Miguel Island, collected at both Simonton Cove and Cuyler Harbor, contains quartz, K-feldspar, plagioclase, calcite, and aragonite and total $\mathrm{CaCO}_{3}$ content (aragonite + calcite) ranges from $\sim 22 \%$ to $\sim 32 \%$. The lower carbonate content of San Miguel Island beach sands compared to both Pleistocene aeolianite and Holocene aeolian sands at the Hobbit House section is also apparent in relative abundances of quartz, plagioclase, and calcite on ternary diagrams (Fig. 11a, b).

We also compared the calcite content of Pleistocene aeolianite on San Miguel Island with aeolianites and coastal dune sands from other localities. On a quartz-plagioclase-calcite ternary diagram, San Miguel Island aeolianites have some overlap with aeolianites from the northern coast of Puerto Rico, although overall, the latter have higher carbonate contents (Fig. 11c). The Sonoyta dunes in the upper Gulf of California, near Puerto Peñasco, Mexico, have quite variable compositions compared to San Miguel Island aeolianites (Fig. 11c). In the Sonoyta dunes, calcite contents are highest on the coast and diminish inland, but all are lower than in aeolianites from San Miguel Island. Along the coastal plain of Israel north of Tel Aviv, there is abundant quartz-rich beach and shelf sand derived primarily from the Nile Delta (Muhs et al. 2013). Calcite content in Israeli aeolianites (relative to quartz and plagioclase) is lower than in those on San Miguel Island (Fig. 11d). From the Canary Islands, Pleistocene aeolianites and aeolian sands on Lanzarote Island have the highest carbonate contents of all sediments we studied (Fig. 11d). Sand-sized quartz is absent on this basaltic island, and the aeolian sediments consist of calcite and aragonite, with much lower amounts of plagioclase.

Aeolianites on San Miguel Island consist largely of fine to medium sands, based on extensive particle size analyses conducted by Johnson 
(a)

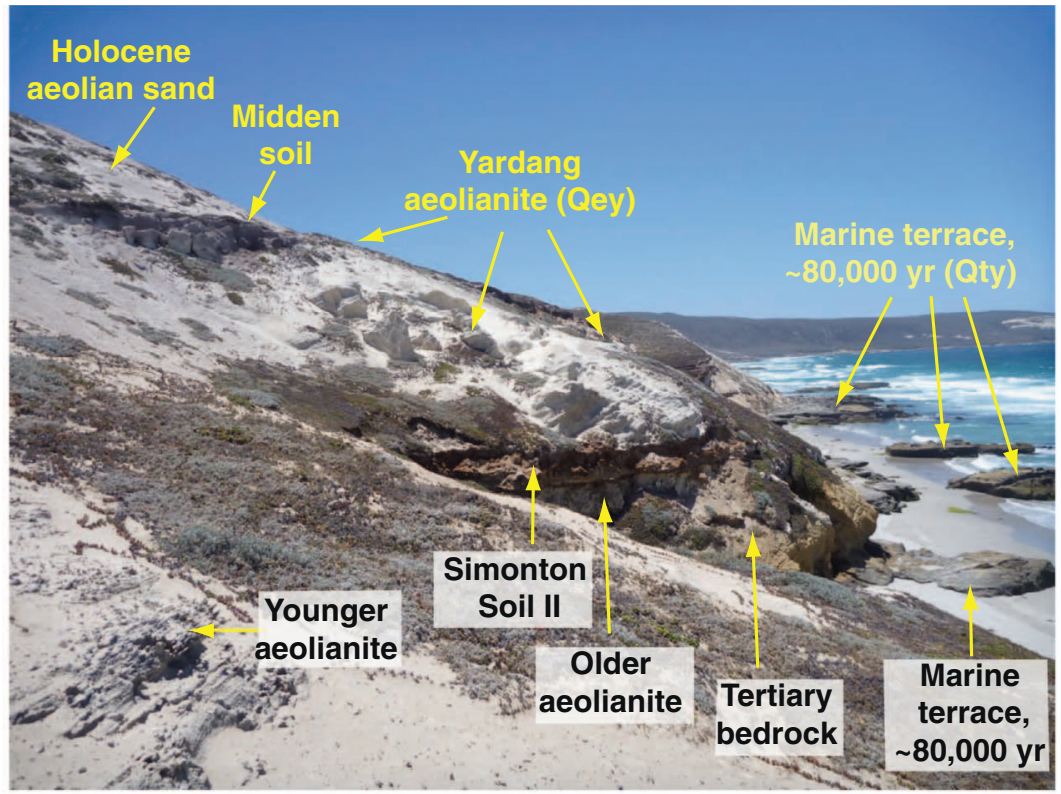

(b)

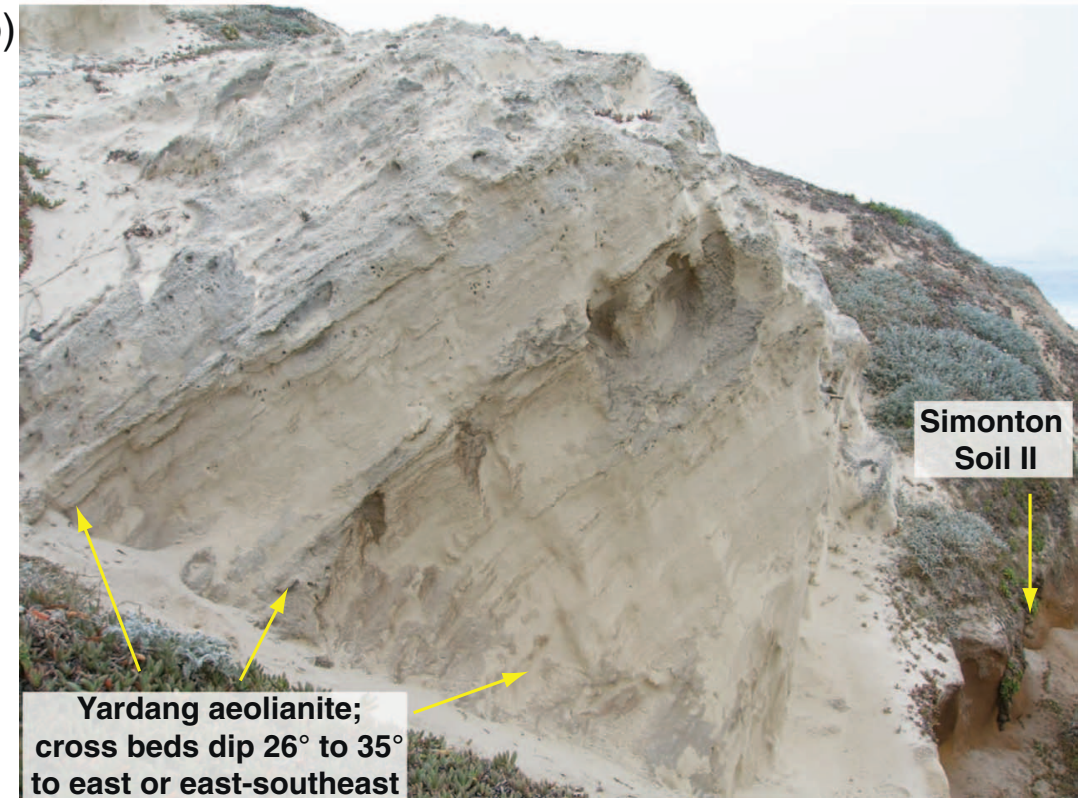

Fig. 8. Photographs showing details of (a) stratigraphy of the upper part of the Hobbit House section on San Miguel Island and (b) high-angle foreset beds of the Yardang aeolianite shown in (a). Photographs by D.R. Muhs.
(1972). He reports a median diameter of $\sim 250 \mu \mathrm{m}$ (2.0 phi) for aeolianites from a variety of localities on the island. Beach sands from San Miguel Island analyzed by Johnson (1972) are only slightly coarser, with a median diameter of $\sim 290 \mu \mathrm{m}$ (about 1.77 phi); sands from localities on other Channel Islands beaches also have median diameters of $\sim 290 \mu \mathrm{m}$ and shelf sands have median diameters of $\sim 260 \mu \mathrm{m}$ (Emery 1960). Holocene and Pleistocene dune sands from Santa Maria, California and San Quintín, Baja California reported by Orme and Tchakerian (1986) have mean particle diameters ranging from $\sim 210 \mu \mathrm{m}(2.25 \mathrm{phi})$ to $\sim 135 \mu \mathrm{m}(2.88 \mathrm{phi})$, indicating that San Miguel Island aeolianites are slightly coarser than mainland aeolian sands.

\subsection{Geochronology of late Quaternary aeolian units on San Miguel Island}

4.4.1. Amino acid geochronology of marine terrace deposits underlying aeolianites

Part of the stratigraphic basis for aeolian sand units on San Miguel Island and the other Channel Islands is their relation to emergent marine terraces. Two low-elevation terraces occur discontinuously along the coastlines of the northern Channel Islands (Muhs et al. 2014, 2015). On the southern coast of San Miguel Island, the lower ( $\sim 3-4 \mathrm{~m})$ terrace is undated, but the higher $(\sim 24 \mathrm{~m})$ of these two terraces has abundant fossils. Uranium-series analyses by Muhs et al. (2014) of solitary corals from deposits of the $\sim 24 \mathrm{~m}$ terrace near Cardwell Point (SMI-236 on Fig. 3) yield ages of $\sim 121,000 \mathrm{yr}$ to $\sim 114,000 \mathrm{yr}$, equivalent to MIS 5.5. On the northern coast of Santa Rosa Island, the higher of the two terraces (also at $\sim 24 \mathrm{~m}$ ) dates to $\sim 120,000 \mathrm{yr}$, as on San Miguel Island, and the lower terrace $(\sim 7 \mathrm{~m})$ dates to $\sim 80,000 \mathrm{yr}$, or MIS 5.1 (Muhs et al. 2015).

As discussed above, two low-elevation terraces are also found on the northern coast of San Miguel Island (Fig. 7) and are hypothesized to date to the same high-sea stands of the last interglacial complex $(\sim 120,000$ and $80,000 \mathrm{yr})$ as those on northern Santa Rosa Island. Fossils are sparse, poorly preserved, and strongly cemented to terrace clasts in deposits of both terraces on the north side of San Miguel Island. We found no corals in the deposits of either terrace, nor did we find any specimens of Chlorostoma (formerly Tegula), which is a favorable genus for amino acid geochronology (Muhs et al. 2014). In deposits of the 2nd 
(a) San Miguel Island

Pleistocene aeolianite

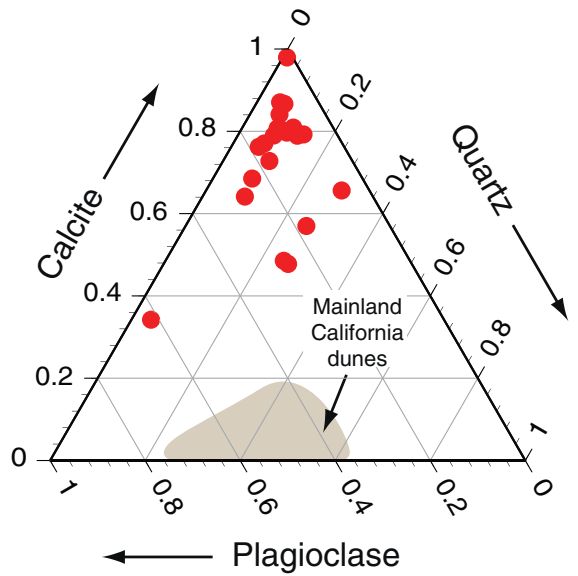

(c) San Nicolas Island

Pleistocene aeolianite

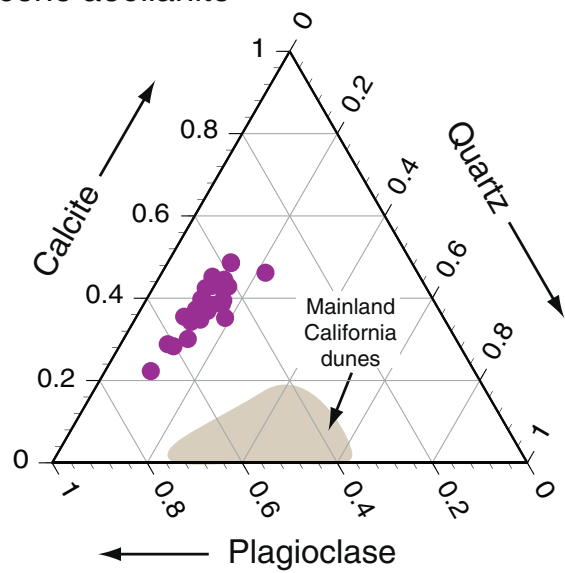

(b) San Miguel Island

Holocene aeolian sand

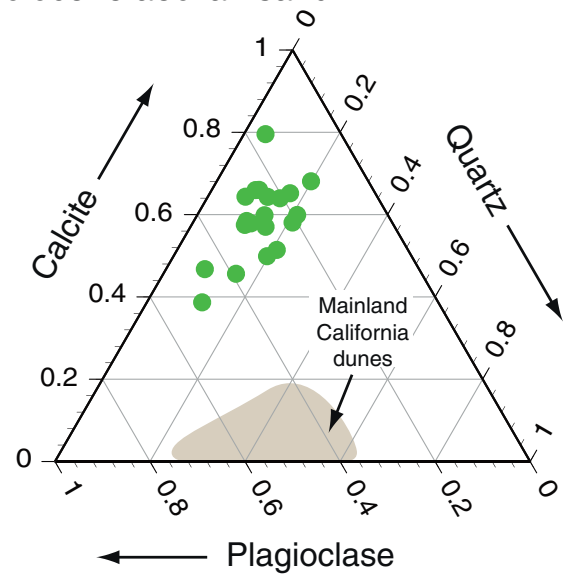

(d) San Nicolas Island modern aeolian sand

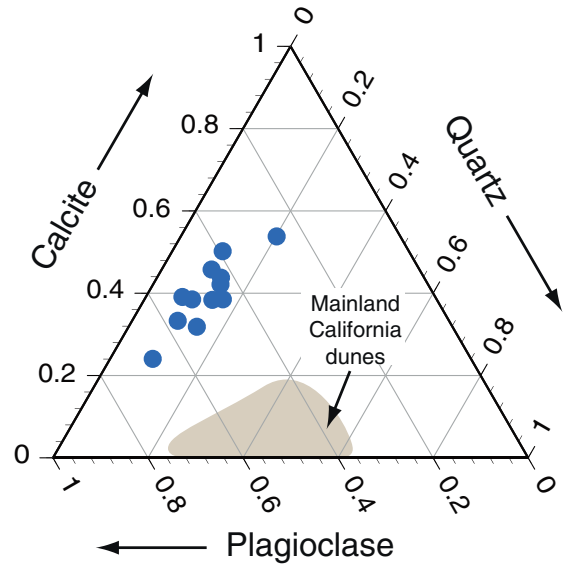

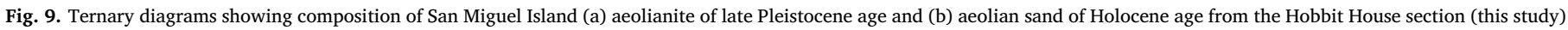

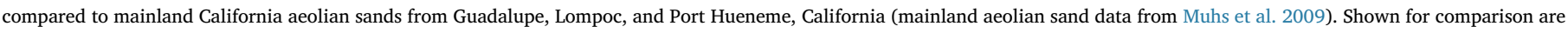

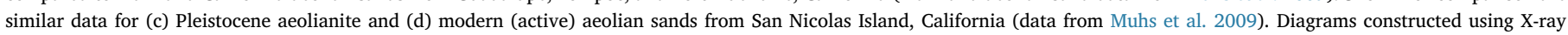

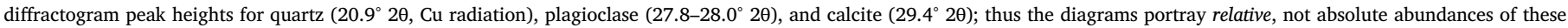
minerals.

terrace at Yardang canyon (SMI-500; Fig. 3), we found a single valve of Epilucina californica, a common intertidal bivalve that has also been used for amino acid geochronology. Although this taxon does not have the discriminating ability of Chlorostoma, it can usually distinguish between $\sim 120,000$-yr-old and $\sim 80,000$-yr-old marine terrace deposits (see Muhs et al. 2014). D/L values in the single Epilucina valve from SMI-500 are 0.43 for glutamic acid and 0.33 for valine (Fig. 12). For comparison, using Epilucina amino acid data in Muhs et al. (2014), the 120,000 -yr-old $(\sim 24 \mathrm{~m})$ terrace on the south side of San Miguel Island has mean D/L values of $0.47 \pm 0.07$ (glutamic acid) and $0.39 \pm 0.07$ (valine). In contrast, the $\sim 7 \mathrm{~m}$ terrace dated to $80,000 \mathrm{yr}$ on the northwest side of Santa Rosa Island (Muhs et al. 2015) has mean D/L values of $0.36 \pm 0.02$ (glutamic acid) and $0.28 \pm 0.02$ (valine). These comparisons support a correlation of the 2nd terrace on the north side of San Miguel Island at SMI-500 with the 2nd terrace on the south side of the island, dated to $\sim 120,000 \mathrm{yr}$.

In addition, we were able to recover three well-preserved specimens of Callianax biplicata (Sowerby, 1825) [formerly Olivella biplicata] at two localities (SMI-50 and SMI-51; Fig. 3) on the lower terrace and at one locality on the higher terrace (SMI-500; Fig. 3) on San Miguel Island. This taxon is one of the most common gastropods in marine terrace deposits of California and Baja California (Valentine, 1980, pp. 1313-1315). Despite its ubiquity in the marine Quaternary fossil record of California, Callianax has not been studied previously for its suitability in amino acid geochronology. Here we tested the species for that purpose, using two methods. The first was measurement of $\mathrm{D} / \mathrm{L}$ values for glutamic acid and valine in Callianax from a flight of marine terraces that likely span much of the Pleistocene on San Nicolas Island, California (Figs. 2b, 13). If amino acid ratios in Callianax are a reliable relative age indicator, $\mathrm{D} / \mathrm{L}$ values in glutamic acid and valine should be higher in higher-elevation (older) terraces. The second method of testing Callianax is from a suite of dated terrace deposits from central and southern California along a southward-increasing temperature gradient (Fig. 14). Locations of terrace deposits used in this study are identical to those used for other species in Muhs et al. (2014). Because amino acid racemization rates decrease with decreasing temperatures, D/L values in Callianax from dated deposits of the same age should be lower from localities with histories of lower average temperature.

Results indicate that on San Nicolas Island, Callianax shows a fair degree of reliability as a relative age indicator. On the Vizcaino PointThousand Springs terrace transect (Fig. 13a), D/L values in both glutamic acid and valine increase systematically with terrace elevation, as hypothesized. The same is true for selected segments of the Celery Creek canyon transect (Fig. 13b), although glutamic acid values for shells from the 4th terrace are lower than would be expected based on a comparison with valine values for shells from this terrace. 


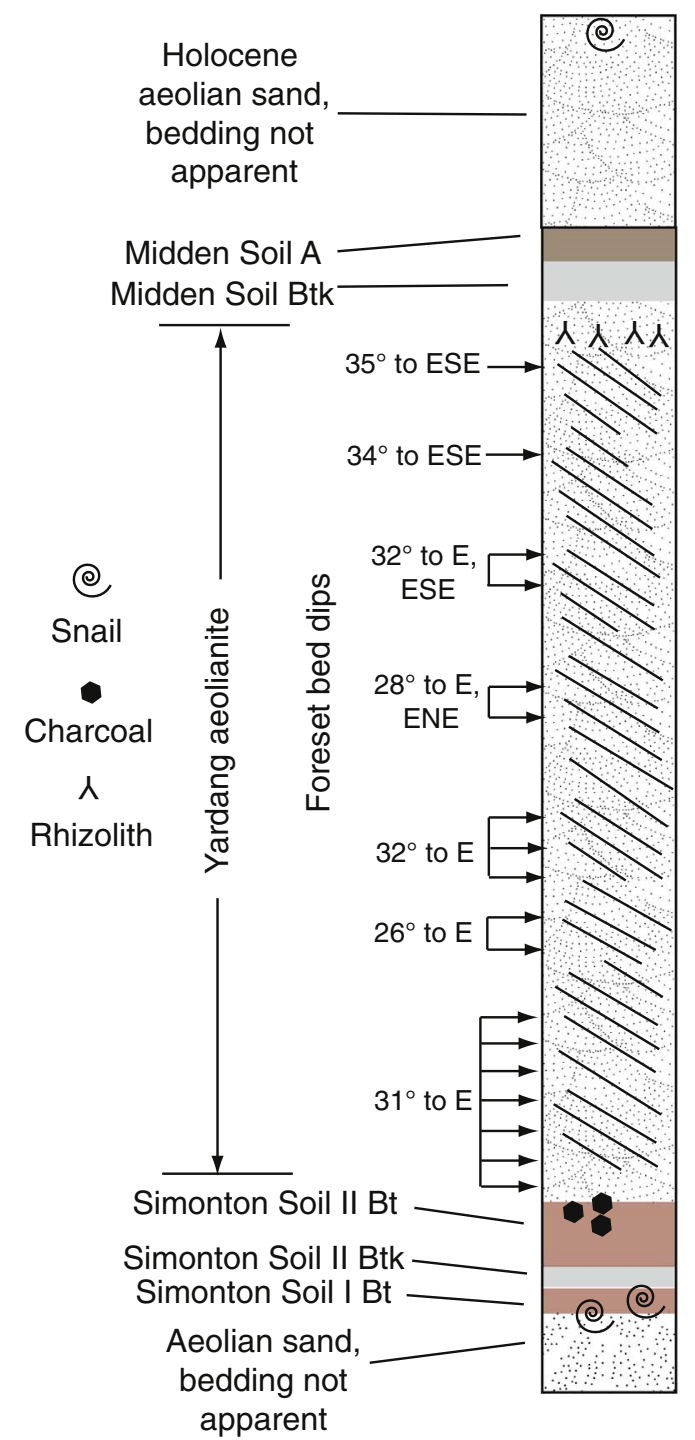

Total $\mathrm{CaCO}_{3}(\%) \quad$ Calcite/quartz

Aragonite/quartz
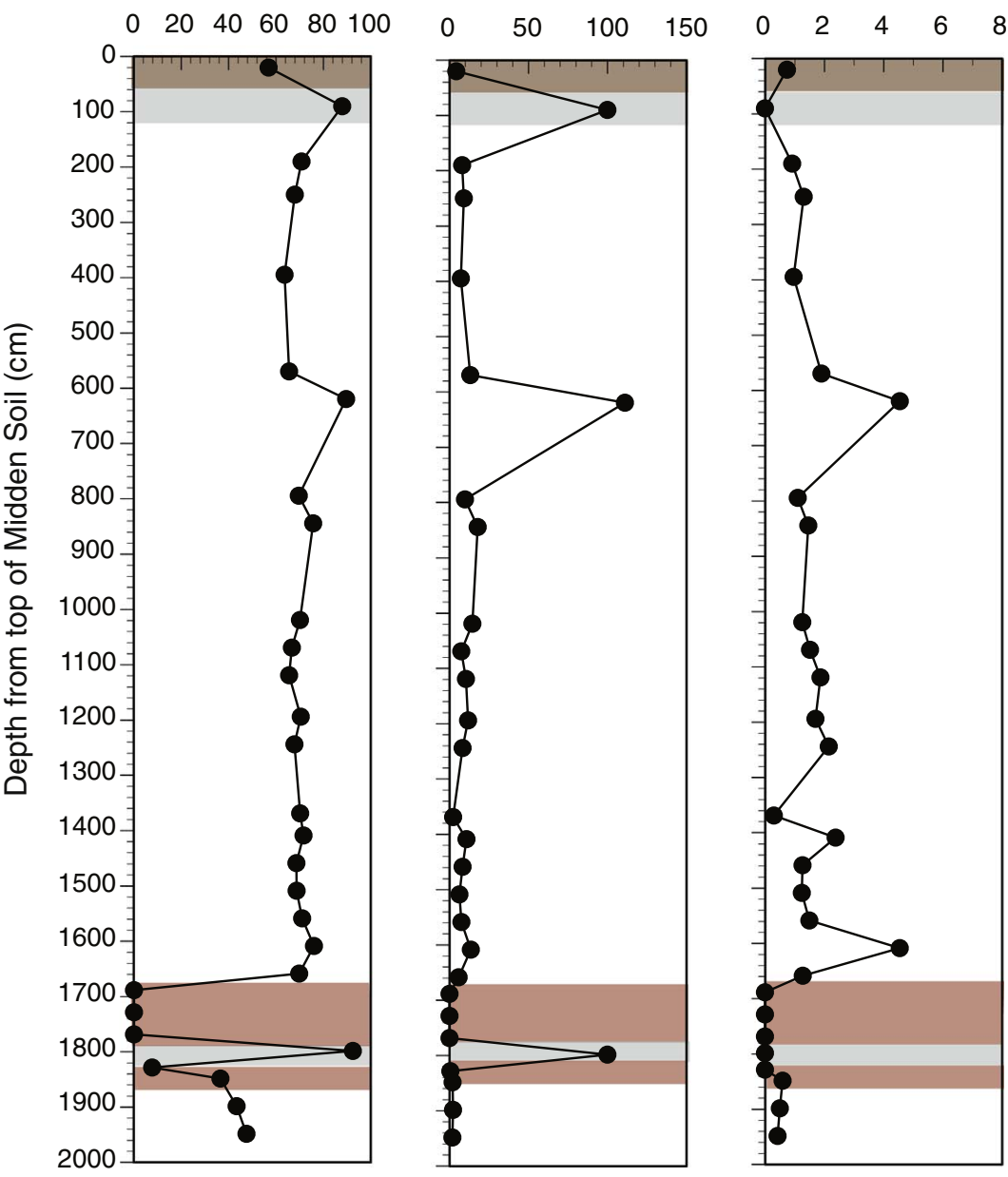

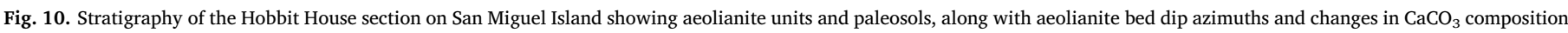

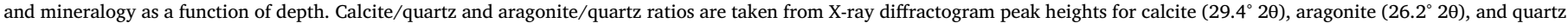
$\left(20.9^{\circ} 2 \theta\right)$.

Alternatively, the glutamic acid values for shells from the 4th terrace may be reasonable if the glutamic acid values for shells from terrace 2a $(0.54 \pm 0.04)$ are too high.

In the latitudinal transect, Callianax biplicata exhibits a fair degree of variability of $\mathrm{D} / \mathrm{L}$ values among shells from the same deposit (Fig. 14). Nevertheless, terraces that date either to the $\sim 120,000 \mathrm{yr}$ high-sea stand (MIS 5.5) or that contain a mix of $\sim 120,000 \mathrm{yr}$ and $\sim 100,000$ yr (MIS 5.3) fossils show generally southward-increasing D/ $\mathrm{L}$ values for both glutamic acid and valine in an "aminozone" band. Fossils from terraces dating to $\sim 80,000 \mathrm{yr}$ again show considerable variability within a single deposit, but these values define an aminozone band that is subparallel to that of the $\sim 120,000 \mathrm{yr}$ fossils. We conclude, therefore, that although Callianax may not be an ideal species for amino acid geochronology, the taxon can be used for relative age discrimination over much of the Pleistocene and can be used to distinguish $\sim 120,000 \mathrm{yr}$ terraces from $\sim 80,000 \mathrm{yr}$ terraces.

The 2nd terrace on the north side of San Miguel Island, at Yardang canyon (SMI-500) yielded three Callianax biplicata shells that were analyzed for D/L values for glutamic acid and valine. Unfortunately, concentrations of valine in these shells were too low to give reliable $\mathrm{D} / \mathrm{L}$ values, and even glutamic acid $\mathrm{D} / \mathrm{L}$ values show considerable variability. Nevertheless, the mean glutamic acid D/L value falls within the general range of values for southern California terraces dating either to $\sim 120,000 \mathrm{yr}$ or containing a mix of corals dating to $\sim 120,000 \mathrm{yr}$ and $\sim 100,000 \mathrm{yr}$ (Fig. 14). The mean D/L value for glutamic acid in Callianax fossils from the 1 st $(\sim 3.5$-m-high) terrace on northern San Miguel Island (SMI-50 and SMI-51) is lower than those in Callianax fossils from the 2nd terrace nearby (SMI-500). Mean D/L values for both glutamic acid and valine from the 3.5-m-high 1st terrace are significantly lower than the dated, $\sim 120,000 \mathrm{yr}, 24$-m-high terrace on the south side of San Miguel Island (SMI-236), and values for both amino acids fall within the $\sim 80,000 \mathrm{yr}$ aminozone bands. We infer from all these analyses that the 2nd terrace on the northern coast of San Miguel Island likely correlates with the $\sim 120,000$-yr high-sea stand (MIS 5.5) and the 1 st terrace likely correlates with the $\sim 80,000$-yr high-sea stand (MIS 5.1).

\subsubsection{Radiocarbon dating of San Miguel Island aeolianites}

We determined the ages of aeolianites on San Miguel Island using AMS radiocarbon dating of charcoal, land snails, and calcite rhizoliths. At Yardang canyon, the aeolianite sequence rests on top of the higher of two marine terraces, which we infer to be $\sim 120,000$ yr old (Fig. 15a). No datable materials were found in the aeolianite on top of the marine deposits or in the paleosol developed in it, where these units are 
(a) San Miguel Island, Pleistocene aeolianite

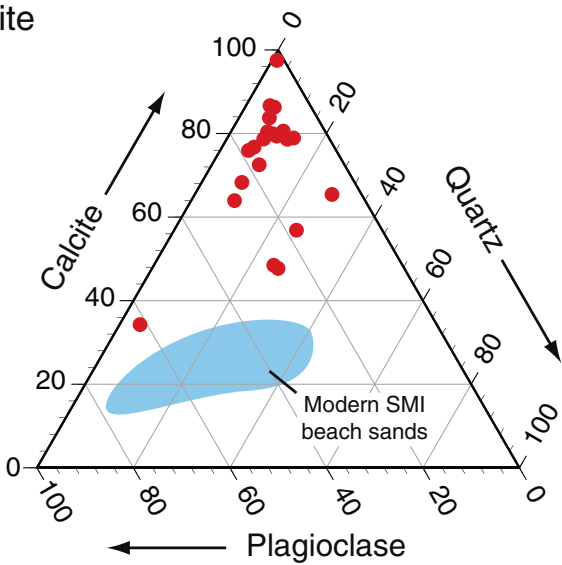

(b) San Miguel Island, Holocene aeolian sand

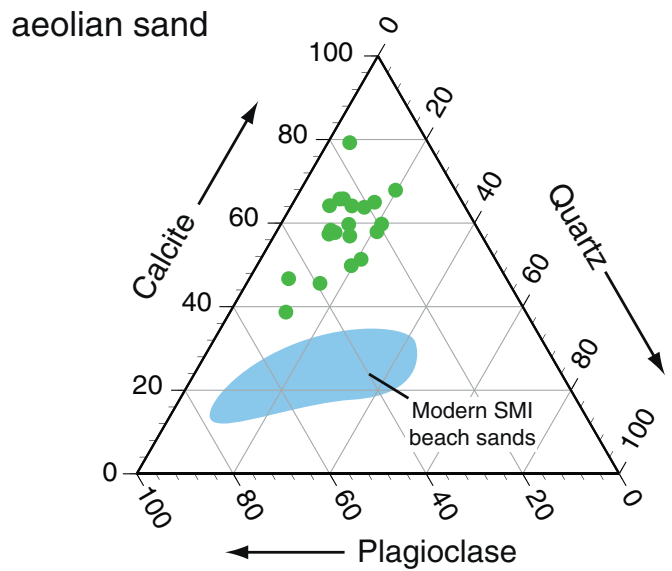

(d) San Miguel

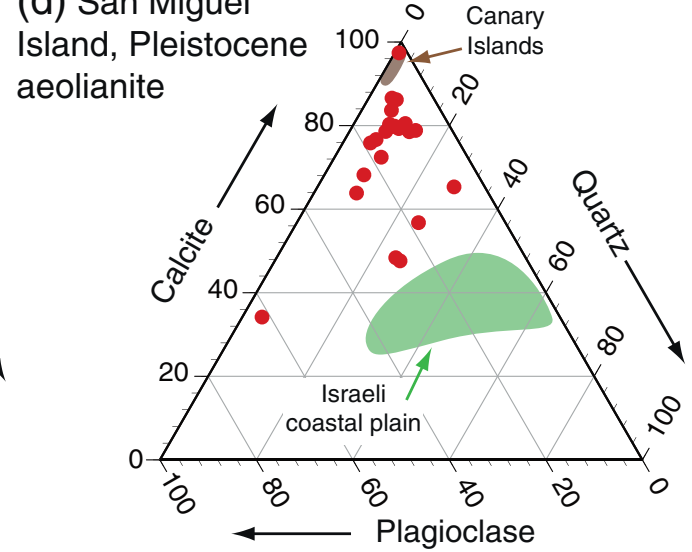

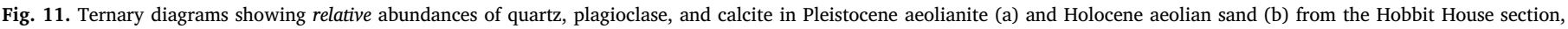

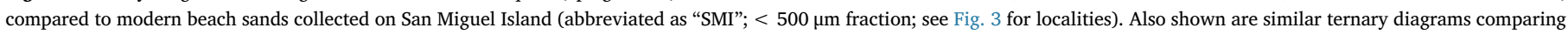

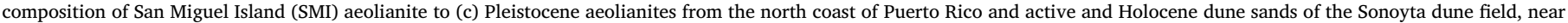

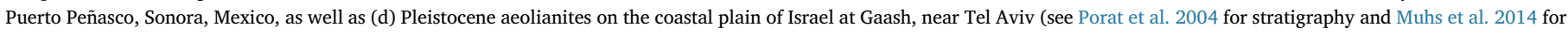

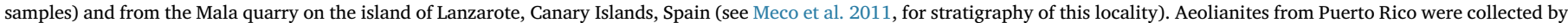

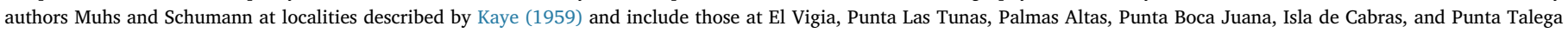
Vacia; samples from the Canary Islands and the Sonoyta dune field were collected by Muhs; samples from Israel were collected by Muhs and Porat.

exposed on the sea cliff. However, $\sim 20 \mathrm{~m}$ landward, in Yardang canyon itself (Fig. 5), both charcoal and land snails were found in the Simonton soil, and gave calibrated radiocarbon ages of $24,480 \pm 260 \mathrm{yr}$ (WW8137) and 24,560 $\pm 310 \mathrm{yr}$ (WW9499), respectively (Table 1; Fig. 15a). From the lowermost part of the Midden soil, we collected four well-preserved rhizoliths that yielded calibrated radiocarbon ages ranging from $17,280 \pm 200 \mathrm{yr}$ (WW9432) to $17,940 \pm 180 \mathrm{yr}$ (WW9433). The rhizoliths all yielded carbon isotopic values over a narrow range of -6.9 to $-7.7 \%$, well within the range of Holocene pedogenic carbonate values (Quade et al. 1989). The rhizolith ages are consistent with calibrated radiocarbon ages of two land snails collected higher in the section, but within the Midden soil, at $\sim 120 \mathrm{~cm}$ depth $(14,060 \pm 110 \mathrm{yr} ; \mathrm{WW} 10073)$ and at $\sim 60 \mathrm{~cm}$ depth $(12,190 \pm 190 \mathrm{yr} ; \mathrm{WW10074)}$. Within the lowermost part of the overlying aeolian sand that we interpret to be of Holocene age, we obtained a calibrated radiocarbon age of $9500 \pm 30 \mathrm{yr}$ (WW10075) on a land snail shell.

At the Tree Trunk section, as is the case at Yardang canyon, the sea cliff exposes what we interpret to be the $\sim 120,000$ yr terrace's outer edge, capped by thin aeolianite with the well-developed Simonton soil in its upper part (Fig. 15b). A land snail collected from the uppermost part of the aeolianite below the Simonton soil yielded a radiocarbon age of $>47,310 \mathrm{yr}$. Landward of the sea cliff, high-angle, cross-bedded aeolianite is exposed in small patches. Foreset beds in these exposures dip landward, to the southeast. A section $\sim 15 \mathrm{~m}$ landward of the sea cliff exposes the uppermost part of the Yardang aeolianite, a fossil tree trunk, and an unusually $(\sim 4 \mathrm{~m})$ thick Midden soil. Charcoal collected from the fossil tree trunk did not survive our pretreatment processing, but humic acids recovered from organic matter in the trunk yielded a calibrated age of 22,850 $\pm 220 \mathrm{yr}$ (WW10421). Charcoal and land snails are abundant within the Midden soil here, which appears to have formed in an accretionary manner, with multiple periods of thin aeolian sand deposition separated by brief periods of pedogenesis. We collected charcoal and snails throughout the Midden soil in an attempt to document the time period over which these cycles occurred. Calibrated radiocarbon ages range from 22,610 $\pm 180 \mathrm{yr}$ (WW10376) near the base of the soil to $15,760 \pm 180 \mathrm{yr}$ (WW10401) near the top of the soil (Fig. 13b). The uppermost age is from a snail and the others are from either charcoal or humic acids. At several depths, we obtained radiocarbon ages from both charcoal and humic acids. Where both were obtained, in all but one case (SMI-335) the paired ages are very close to one another, when analytical uncertainties are considered (Table 1). Overall, the results indicate a fairly long $(\sim 6800 \mathrm{yr})$ period of pedogenesis punctuated by periodic minor additions of aeolian sand. 


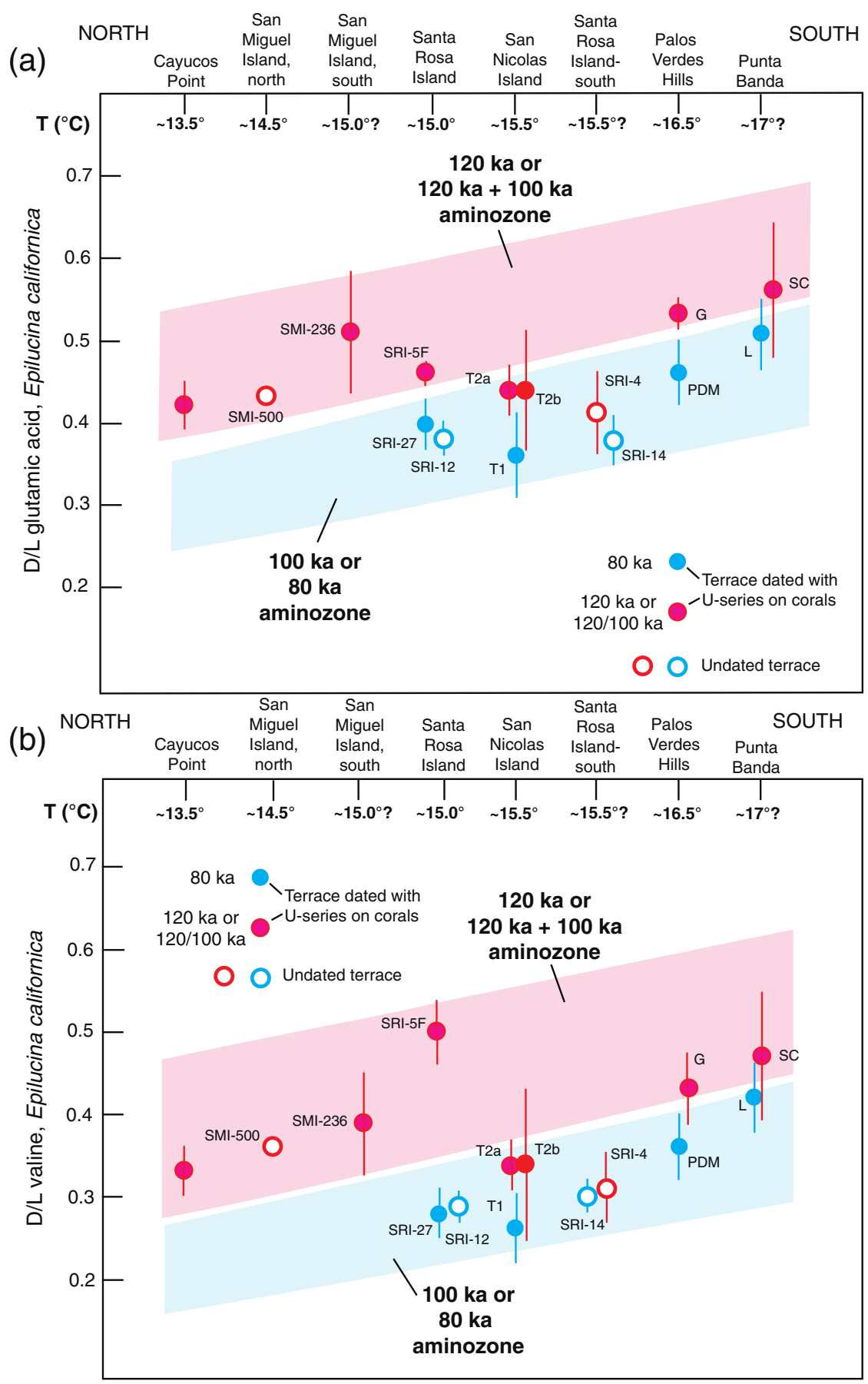

Fig. 12. (a) Plot of mean $\mathrm{D} / \mathrm{L}$ ratios in glutamic acid (vertical axis) in fossil Epilucina californica from dated (filled circles) and undated (open circles) marine terraces on the California and Baja California coast, shown as a function of present mean annual air temperature. Error bars are \pm 1 standard deviation, based on $\mathrm{D} / \mathrm{L}$ ratios in 4 to 6 individual shells from the same deposit. Shaded bands indicate correlation between fossil localities of the same age based on U-series dating of corals. Terrace name abbreviations: SMI, San Miguel Island, SRI, Santa Rosa Island; PDM, Paseo del Mar terrace; G, Gaffey terrace; L, Lighthouse terrace; SC, Sea Cave terrace; see Muhs et al. (1994, 2002a, 2006, 2012b, 2014) for terrace stratigraphic names and U-series ages. (b) Same as in (a), but for mean D/L ratios in valine. All data shown are peak area ratios derived from supplementary data given in Muhs et al. (2014) except for SMI-500, which is from the present study.

From the Hobbit House section, we obtained ages from snails, charcoal, and rhizoliths from the bottom and top of the exposure (Fig. 16). Snails from the Simonton I soil, collected at two depths, both gave ages $>50,000 \mathrm{yr}$. Above this, in the Simonton II soil, charcoal at successively shallower depths gave successively younger calibrated ages of 36,200 $\pm 1210 \mathrm{yr}$ (WW9472), 26,740 $\pm 420 \mathrm{yr}$ (WW9471), and 26,100 $\pm 180 \mathrm{yr}$ (WW8135). The two uppermost ages are in fair agreement (within a couple thousand years) of the ages from the Simonton soil at Yardang canyon, which suggests that the single paleosol exposed at Yardang canyon that both we and Johnson (1977) called the Simonton soil is equivalent to Simonton soil II at the Hobbit House section. Rhizoliths collected in the upper part of the Yardang aeolianite but below the Midden soil at the Hobbit House section gave a narrow range of calibrated radiocarbon ages, from $14,910 \pm 210 \mathrm{yr}$
(WW8134) to 13,490 $\pm 70 \mathrm{yr}$ (WW8132) (Fig. 15 and Table 1). These rhizoliths have $\delta^{13} \mathrm{C}$ values of -6.8 to $-7.2 \%$, similar to those at Yardang canyon and well within the range of Holocene pedogenic carbonate values (Quade et al. 1989). Finally a snail collected $\sim 3.6 \mathrm{~m}$ above the Midden soil, within the thick Holocene aeolian sand package gave a calibrated age of $8060 \pm 100 \mathrm{yr}$ (WW9496).

From all these calibrated radiocarbon ages, we can constrain the ages of the four aeolian units exposed at the Hobbit House section. The oldest aeolianite is younger than $\sim 120,000 \mathrm{yr}$ (based on the inferred age of the underlying marine terrace), but $>50,000 \mathrm{yr}$, based on the snail ages. The thin aeolianite above this is likely younger than $\sim 50,000 \mathrm{yr}$, but older than $\sim 36,000 \mathrm{yr}$. The thick $(\sim 17 \mathrm{~m})$ Yardang aeolianite was deposited between $\sim 26,000 \mathrm{yr}$ and $\sim 15,000 \mathrm{yr}$. The Midden soil formed between $\sim 13,500 \mathrm{yr}$ and $\sim 8000 \mathrm{yr}$, a much 
(a) Vizcaino Point-Thousand Springs area:

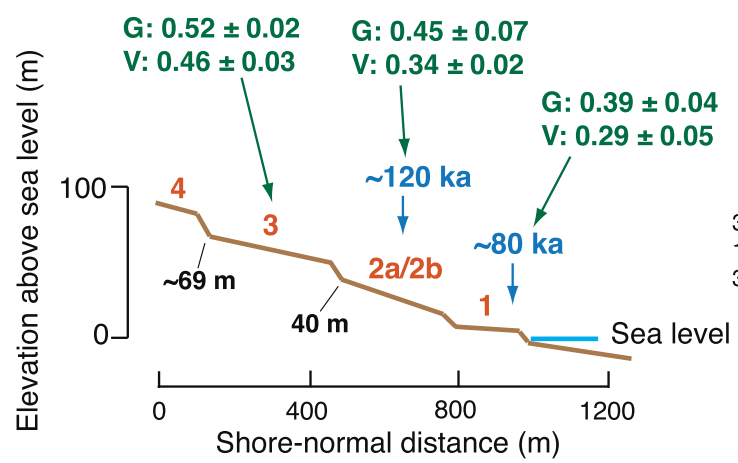

(b) Celery Creek Canyon:
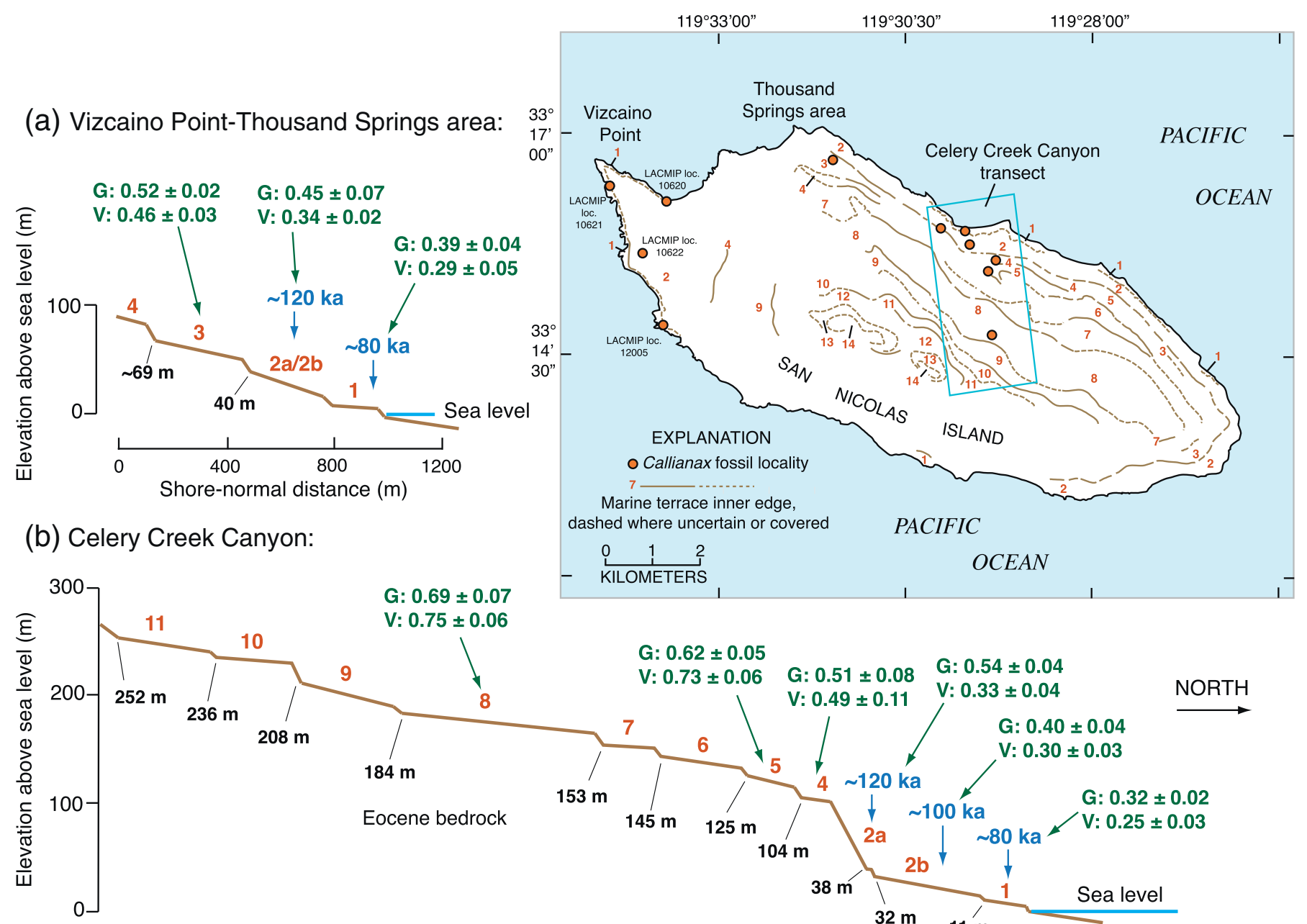

G: $0.69 \pm 0.07$

V: $0.75 \pm 0.06$

G: $0.62 \pm 0.05$

V: $0.73 \pm 0.06$ G: $0.51 \pm 0.08 \quad$ G: $0.54 \pm 0.04$

$\begin{array}{ll}G: 0.51 \pm 0.08 & \text { V: } 0.33 \pm 0.04\end{array}$

8

$184 \mathrm{~m}$

Eocene bedrock

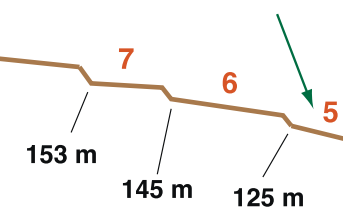

$0.49 \pm 0.11$

G: $0.40 \pm 0.04$

NORTH

$\mathrm{V}: 0.30 \pm 0.03$

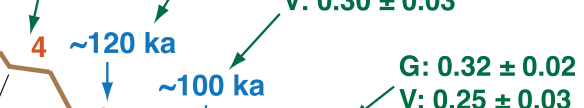

Shore-normal distance along Celery Creek (m)

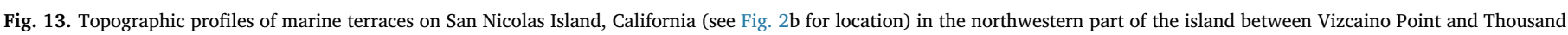

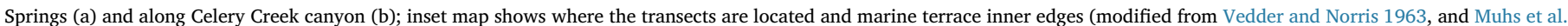

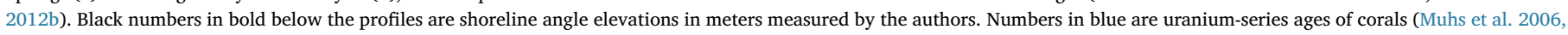

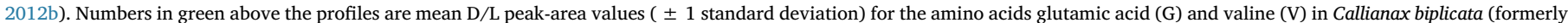

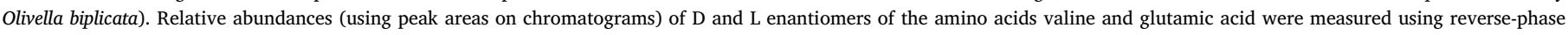

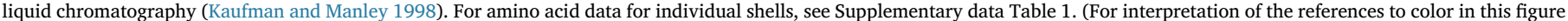
legend, the reader is referred to the web version of this article.)

younger estimate compared to what we observed at the Tree Trunk section. Holocene aeolian sand deposition began well after $\sim 13,500 \mathrm{yr}$, was in progress by $\sim 8000 \mathrm{yr}$, and continued until some considerable time later, based on the thickness $(\sim 30 \mathrm{~m})$ of the entire Holocene section.

Although the Beachrock section is limited in its vertical extent, it provides some additional geochronology for the oldest two aeolianites that are thin or missing at the other sections (Fig. 17). Here, close to $6 \mathrm{~m}$ of the oldest aeolianite occurs on top of the 1st marine terrace, which amino acids (described above) indicate is likely equivalent to the $\sim 80,000$ yr terrace found on nearby Santa Rosa Island. Snails within the upper part of this aeolianite gave ages of $\geq 46,690 \mathrm{yr}$ and $>$ $50,000 \mathrm{yr}$, but charcoal slightly above these snails gave an apparently finite age of 47,980 $\pm 1980 \mathrm{yr}$ (WW10088). We consider it very likely that this is an infinite age, however, because charcoal above this sample gave an age of $>50,000$. From the uppermost part of Simonton soil I, charcoal gave an age of $36,300 \pm 630 \mathrm{yr}$ (WW10090), but this is not consistent with either snail or charcoal ages above it of $43,450 \pm 950 \mathrm{yr}(\mathrm{WW} 10072)$ and 40,960 $\pm 810 \mathrm{yr}$ (WW10089)
(Fig. 17). Although the minimum-limiting ages and one stratigraphic reversal make interpretations tentative, we certainly can infer that the lower aeolianite was deposited after $\sim 80,000 \mathrm{yr}$ and before $\sim 50,000 \mathrm{yr}$, and the upper aeolianite is at least $\sim 40,000 \mathrm{yr}$ old. Thus, although the age ranges are broadly consistent with the age estimates of these units at the Hobbit House section, more work is needed before firm conclusions can be reached about the ages of the older aeolianites.

4.4.3. Optically stimulated luminescence (OSL) and infrared stimulated luminescence (IRSL) geochronology of San Miguel Island aeolianites

To complement the radiocarbon ages, OSL (on quartz) and IRSL (on K-feldspar) ages were determined on a suite of samples from the Hobbit House section (Table 2). At this section we sampled the uppermost part of the "older aeolianite" in which the Simonton soil I is developed, at two depths within the Simonton soil II, at four depths through the vertical extent of the Yardang aeolianite, and at two depths within the Midden soil. A surface sample (listed as a "modern analog" in Table 2) from active, unvegetated aeolian sand at "Sandblast Pass" on San Miguel Island (N3401.923'; W120²2.101'; elevation = $238 \mathrm{~m}$ ) gave a De 


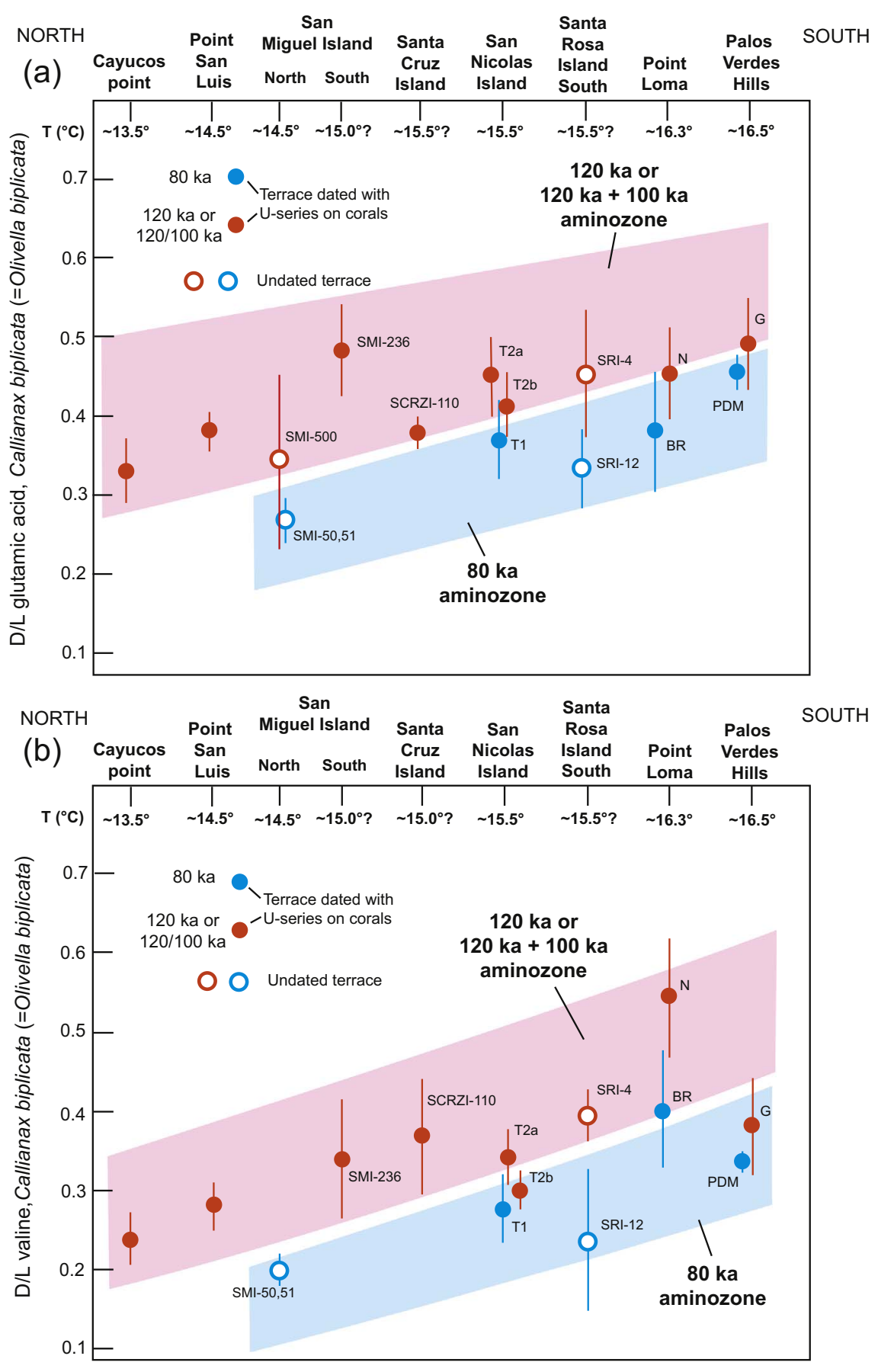

Fig. 14. (a) Plot of mean D/L ratios in glutamic acid (vertical axis) in fossil Callianax biplicata from dated (filled circles) and undated (open circles) marine terraces on the California coast, shown as a function of present mean annual air temperature. Error bars are \pm 1 standard deviation, based on D/L ratios in 4 to 6 individual shells from the same deposit. Shaded bands indicate correlation between fossil localities of the same age based on U-series dating of corals. Terrace name abbreviations: SMI, San Miguel Island, SRI, Santa Rosa Island; N, Nestor; BR, Bird Rock; PDM, Paseo del Mar; G, Gaffey; see Muhs et al. (1994, 2002a, 2006, 2012b, 2014) for terrace stratigraphic names and U-series ages. (b) Same as in (a), but for mean D/L ratios in valine. All points plotted are peak area ratios; for detailed data for individual shells, as well as peak height data, see Supplementary data Table 1 .

value of $\sim 0.06 \mathrm{~Gy}$ and an age of $\sim 15$ years, indicating that in this specific environment, the quartz grains are well bleached.

In the IRSL analyses of the K-feldspars (KF), the fading-corrected $\mathrm{IR}_{50}$ ages are on average $13 \%$ younger than the pIR-IR 290 ages. The relatively high O-D in quartz measured in some aeolianite samples (40-54\%) implies either partial bleaching even under what should be considered optimal bleaching conditions, or differential exposure to beta dose. Because the pIR-IR 290 bleaches at rates substantially lower than either the $\mathrm{IR}_{50}$ or quartz OSL (Porat et al. 2001; Kars et al. 2014), we infer that the pIR-IR 290 ages could, for at least some samples, overestimate the time of deposition due to poor bleaching. Indeed, for many samples the fading-corrected $\mathrm{IR}_{50}$ ages agree best with quartz OSL ages and the radiocarbon chronology.

The lowermost unit analyzed is from the middle of the Bt horizon of Simonton soil I (SMI-2). A multigrain OSL age for this is
$101,000 \pm 8000 \mathrm{yr}$, but we consider this to be an overestimation due to the presence of grains whose natural signal could not be recovered and which contributed to the natural signal of the multigrain measurements. Single grain (SG) measurements agree with the notion that the marine terrace underlying the aeolianite in which the Simonton soil I is developed dates to $\sim 120,000 \mathrm{yr}$, with a SG FMM major component age of $81,000 \pm 4000 \mathrm{yr}$. The youngest single-grain age component of that sample $(48,000 \pm 3000 \mathrm{yr})$ is concordant with the radiocarbon ages from this stratigraphic position of $>50,000 \mathrm{yr}$ (Fig. 16b). The $\mathrm{IR}_{50}$ (all $\mathrm{IR}_{50}$ ages mentioned are corrected for fading) and pIR-IR 290 ages of $75,000 \pm 11,000 \mathrm{yr}$ and $63,000 \pm 4000 \mathrm{yr}$, respectively, indicate that some processes not fully understood have affected the grains in this paleosol.

Above this, in the lower Bt horizon of Simonton soil II (SMI-3), multigrain OSL of quartz yielded an age of 50,000 $\pm 3000 \mathrm{yr}$. SG 

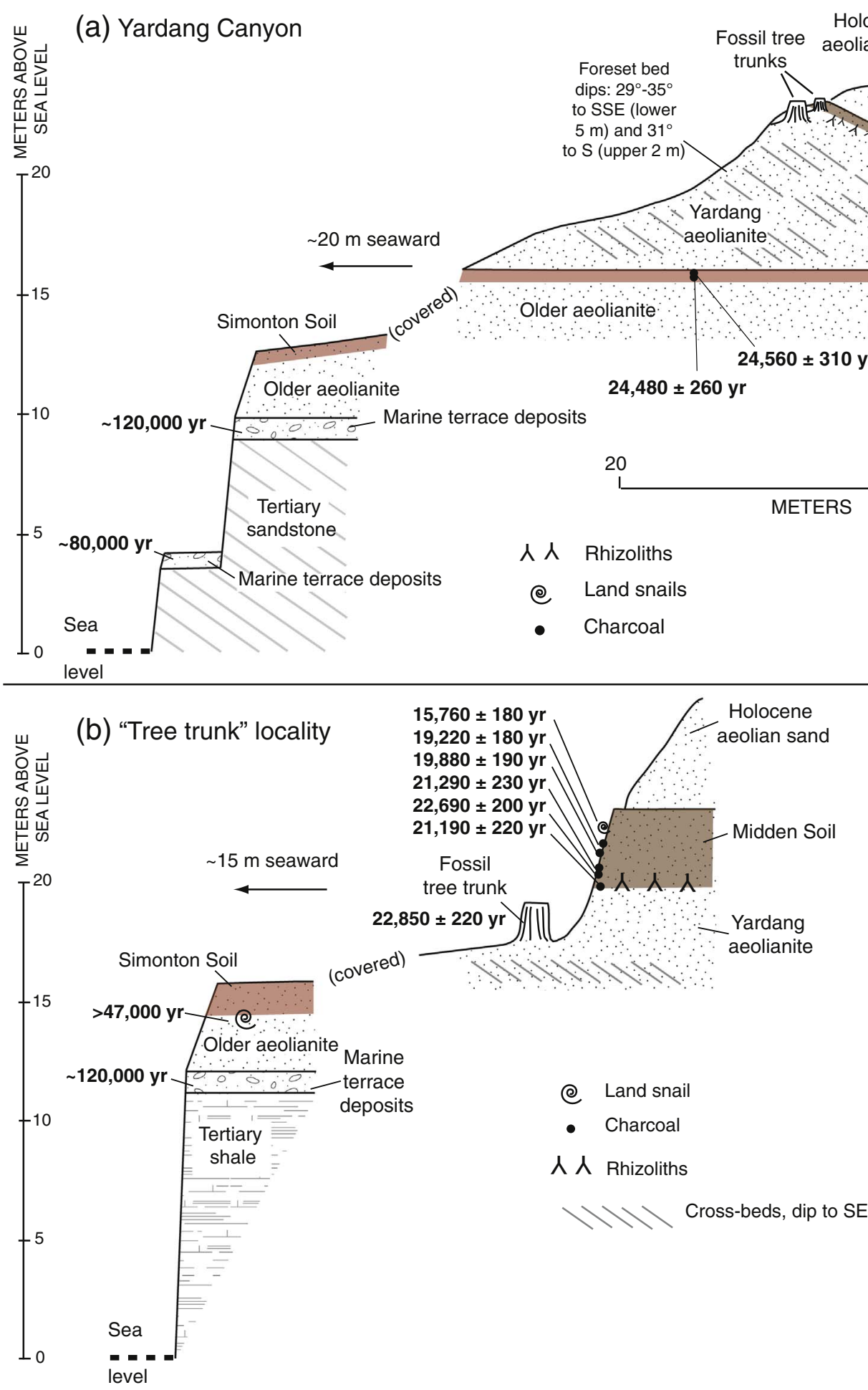

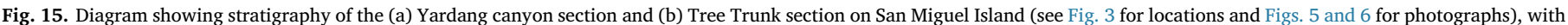
calibrated radiocarbon ages of land snails, charcoal, and rhizoliths (from Table 1).

analyses gave ages of $67,000 \pm 3000 \mathrm{yr}$ (major component) and $41,000 \pm 2000 \mathrm{yr}$ (youngest component). K-feldspar analyses gave pIR-IR 290 and $\mathrm{IR}_{50}$ ages of $54,000 \pm 2000 \mathrm{yr}$ and $48,000 \pm 7000 \mathrm{yr}$, respectively. These ages give a rather wide range of $48,000 \mathrm{yr}$ to $67,000 \mathrm{yr}$, which probably reflects processes that took place within Simonton soil II during transport, deposition and pedogenesis, such as partial bleaching and possible grain infiltration. Above this, in the upper part of the Simonton soil II Bt horizon (SMI-4), the OSL multigrain age is $44,000 \pm 3000 \mathrm{yr}$ while the pIRIR 290 age is somewhat younger $(35,000 \pm 2000 \mathrm{yr})$. Taken together with the $\mathrm{IR}_{50}$ age $(38,000 \pm 6000$ year), the K-feldspar ages agree with two radiocarbon ages of $\sim 36,000-26,000 \mathrm{cal}$ yr from that soil. While OSL and IRSL ages date the time aeolian-transported grains were deposited and reflect transport, deposition and pedogenic processes, the charcoal samples date from the time of pedogenesis, after stabilization of the aeolian sand. Thus, the best interpretation for all ages from Simonton soil II suggests sand deposition starting at $\sim 67,000 \mathrm{yr}$ (the oldest SG component), continuing at a relatively slow rate up to $\sim 40,000 \mathrm{yr}$, 
Table 1

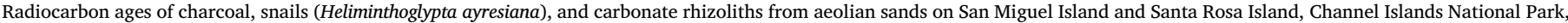
California

\begin{tabular}{|c|c|c|c|c|c|c|c|c|c|}
\hline USGS $^{\mathrm{a}}$ & CAMS\# & Field ID\# & Geologic unit & Material & $\delta^{13} \mathrm{C}^{\mathrm{b}}(\%)$ & ${ }^{14} \mathrm{C}^{\mathrm{C}}$ age & \pm & $\begin{array}{l}\text { Calibrated age } \mathrm{d}^{\mathrm{d}} \\
\text { midpoint }\end{array}$ & \pm \\
\hline \multicolumn{10}{|c|}{ San Miguel Island } \\
\hline \multicolumn{10}{|c|}{ Simonton Cove, Yardang canyon (N34 $4^{\circ} 3.253^{\prime}$; W120 $\left.23.090^{\prime}\right)$} \\
\hline WW10075 & 168,364 & SMI-321 & Holocene sand immediately above top of Midden soil & Snail & -6.5 & 8490 & 30 & 9500 & 30 \\
\hline WW10074 & 168,363 & SMI-320 & Midden soil, $60 \mathrm{~cm}$ below top & Snail & -5.4 & 10,335 & 30 & 12,190 & 190 \\
\hline WW10073 & 168,362 & SMI-319 & Midden soil, $120 \mathrm{~cm}$ below top & Snail & -8.9 & 12,165 & 30 & 14,060 & 110 \\
\hline WW9430 & 161,491 & SMI-206 & Lower part of Midden soil & Rhizolith & -6.9 & 14,735 & 50 & 17,920 & 180 \\
\hline WW9431 & 161,492 & SMI-207 & Lower part of Midden soil & Rhizolith & -7.7 & 14,530 & 50 & 17,720 & 190 \\
\hline WW9432 & 161,493 & SMI-208 & Lower part of Midden soil & Rhizolith & -7.4 & 14,190 & 50 & 17,280 & 200 \\
\hline WW9433 & 161,494 & SMI-209 & Lower part of Midden soil & Rhizolith & -7.5 & 14,750 & 50 & 17,940 & 180 \\
\hline WW9499 & 162,624 & SMI-203 & Simonton soil II (?), $10 \mathrm{~cm}$ below top of paleosol & Snail & -3.7 & 20,400 & 70 & 24,560 & 310 \\
\hline WW8137 & 149,537 & SMI-202 & Simonton soil II (?), $40 \mathrm{~cm}$ below top of paleosol & Charcoal & -24.1 & 20,370 & 50 & 24,480 & 260 \\
\hline \multicolumn{10}{|c|}{ Simonton Cove "Hobbit House" section: (N34 $03.510^{\prime}$; W120 $22.690^{\prime}$ ) } \\
\hline WW9496 & 162,621 & SMI-22 & Holocene sand, $3.6 \mathrm{~m}$ above Midden soil & Snail & -5.2 & 7225 & 35 & 8060 & 100 \\
\hline WW8132 & 149,532 & SMI-53A & Lower part of Midden soil, $2.0 \mathrm{~m}$ below top of soil & Rhizolith & -7.2 & 11,640 & 30 & 13,490 & 70 \\
\hline WW8133 & 149,533 & SMI-53B & Lower part of Midden soil, $2.0 \mathrm{~m}$ below top of soil & Rhizolith & -6.9 & 12,090 & 30 & 13,940 & 140 \\
\hline WW8134 & 149,534 & SMI-53C & Lower part of Midden soil, $2.0 \mathrm{~m}$ below top of soil & Rhizolith & -7.1 & 12,570 & 30 & 14,910 & 210 \\
\hline WW9434 & 161,495 & SMI-53D & Lower part of Midden soil, $2.0 \mathrm{~m}$ below top of soil & Rhizolith & -6.8 & 12,560 & 40 & 14,880 & 260 \\
\hline WW8135 & 149,535 & SMI-30 & Upper Bt horizon of Simonton soil II, $\sim 0.2 \mathrm{~m}$ below top & Charcoal & -22.8 & 21,890 & 60 & 26,100 & 180 \\
\hline WW9471 & 161,918 & SMI-306 & Simonton soil II, $30 \mathrm{~cm}$ below top & Charcoal & -24.8 & 22,440 & 140 & 26,740 & 420 \\
\hline WW9472 & 161,919 & SMI-307 & Simonton soil II, 55-60 cm below top & Charcoal & -23.9 & 32,170 & 470 & 36,200 & 1210 \\
\hline WW9497 & 162,622 & SMI-304 & Simonton soil I, $160-180 \mathrm{~cm}$ below top of Simonton soil II & Snail & -6.8 & 47,500 & 1900 & $\geq 50,000$ & \\
\hline WW9498 & 162,623 & SMI-305 & Simonton soil I, $200 \mathrm{~cm}$ below top of Simonton soil II & Snail & -5.1 & 50,500 & 2700 & $\geq 50,000$ & \\
\hline \multicolumn{10}{|c|}{ 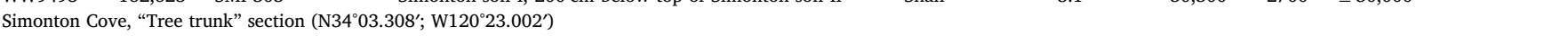 } \\
\hline WW10401 & 170,610 & SMI-334 & Midden soil, $100 \mathrm{~cm}$ below top & Snail & -7.3 & 13,115 & 30 & 15,760 & 180 \\
\hline WW10383 & 170,407 & SMI-333 humic & Midden soil, $145 \mathrm{~cm}$ below top & Humic acids & -25.8 & 13,435 & 30 & 16,160 & 150 \\
\hline WW10384 & 170,408 & SMI-335 humic & Midden soil, $170 \mathrm{~cm}$ below top & Humic acids & -25 & 14,880 & 35 & 18,090 & 160 \\
\hline WW10385 & 170,409 & SM1-335 charcoal & Midden soil, $170 \mathrm{~cm}$ below top & Charcoal & -23.8 & 15,935 & 35 & 19,220 & 180 \\
\hline WW10381 & 170,405 & SMI-332 humic & Midden soil, $205 \mathrm{~cm}$ below top & Humic acids & -24.0 & 16,135 & 35 & 19,460 & 160 \\
\hline WW10382 & 170,406 & SMI-332 charcoal & Midden soil, $205 \mathrm{~cm}$ below top & Charcoal & -24.1 & 16,490 & 40 & 19,880 & 190 \\
\hline WW10379 & 170,403 & SMI-331 humic & Midden soil, $260 \mathrm{~cm}$ below top & Humic acids & -25.8 & 17,300 & 40 & 20,860 & 180 \\
\hline WW10380 & 170,404 & SMI-331 charcoal & Midden soil, $260 \mathrm{~cm}$ below top & Charcoal & -26.0 & 17,620 & 40 & 21,290 & 230 \\
\hline WW8136 & 149,536 & SMI-225 & Midden soil, $\sim 260 \mathrm{~cm}$ below top & Charcoal & -26.9 & 18,835 & 45 & 22,690 & 200 \\
\hline WW10377 & 170,401 & SMI-330 humic & Midden soil, $320 \mathrm{~cm}$ below top & Humic acids & -26.6 & 17,380 & 40 & 20,980 & 200 \\
\hline WW10378 & 170,402 & SMI-330 charcoal & Midden soil, $320 \mathrm{~cm}$ below top & Charcoal & -26.7 & 17,545 & 45 & 21,190 & 220 \\
\hline WW10376 & 170,400 & SMI-329 humic & Midden soil, $385 \mathrm{~cm}$ below top & Humic acids & -24.0 & 18,750 & 45 & 22,610 & 180 \\
\hline WW10421 & 170,630 & SMI-224 humic & From fossil tree trunk & Humic acids & -23.4 & 18,990 & 45 & 22,850 & 220 \\
\hline WW10402 & 170,611 & SMI-336 & Lower eolian sand, just below Simonton soil I (?) & Snail & -4.2 & 45,590 & 800 & $\geq 47,310$ & \\
\hline \multicolumn{10}{|c|}{ Simonton Cove "Beachrock" section: (N34 $03.494^{\prime}$; W120 $\left.22.833^{\prime}\right)$} \\
\hline WW10089 & 168,378 & SMI-318 & $\sim 2 \mathrm{~m}$ below top of section, $20 \mathrm{~cm}$ above eolian sand & Charcoal & -21.6 & 36,400 & 410 & 40,960 & 810 \\
\hline WW10072 & 168,361 & SMI-317 & On surface of Simonton soil I & Snail & -4.0 & 39,630 & 590 & 43,450 & 950 \\
\hline WW10090 & 168,379 & SMI-316 & Simonton soil I, $3 \mathrm{~cm}$ below top of paleosol & Charcoal & -25.3 & 32,390 & 250 & 36,300 & 630 \\
\hline WW10087 & 168,376 & SMI-314 & Simonton soil I, $25-28 \mathrm{~cm}$ below top of paleosol & Charcoal & -22.0 & 47,400 & 1500 & $\geq 50,000$ & \\
\hline WW10088 & 168,377 & SMI-315 & Lower eolian sand, $35 \mathrm{~cm}$ below top of Simonton soil I & Charcoal & -25.1 & 44,600 & 1100 & 47,980 & 1980 \\
\hline WW10071 & 168,360 & SMI-313 & Lower eolian sand, $75 \mathrm{~cm}$ below top of Simonton soil I & Snail & -3.7 & 47,600 & 1600 & $\geq 50,000$ & \\
\hline WW10070 & 168,359 & SMI-312 & Lower eolian sand, $110 \mathrm{~cm}$ below top of Simonton soil I & Snail & -4.2 & 45,700 & 1200 & $\geq 46,690$ & \\
\hline \multicolumn{10}{|c|}{ Santa Rosa Island } \\
\hline \multicolumn{10}{|c|}{ Sandy Point (N34 $\left.00.521^{\prime} ; \mathrm{W} 120^{\circ} 14.330^{\prime}\right)$} \\
\hline WW9470 & 161,917 & SRI-45 & Thin midden deposit in Holocene aeolian sand, $2.85 \mathrm{~m}$ & Sea urchin & -1.3 & 4860 & 30 & 5570 & 80 \\
\hline WW9438 & 161,499 & SRI-82 & Pleistocene aeolian sand, $5.53 \mathrm{~m}$ depth & Rhizolith & -7.1 & 25,720 & 190 & 29,950 & 560 \\
\hline WW9437 & 161,498 & SRI-79 & Pleistocene aeolian sand, $7.83 \mathrm{~m}$ depth & Rhizolith & -7.2 & 24,420 & 160 & 28,420 & 370 \\
\hline \multicolumn{10}{|c|}{ Carrington Point (N34 01.837'; W120 03.641') } \\
\hline WW10708 & 172,816 & SRI-140-H lower & Uppermost paleosol in Holocene aeolian sand & Snail & -6.6 & 655 & 25 & 610 & 60 \\
\hline WW10706 & 172,814 & SRI-140-D upper & Lowermost paleosol in Holocene aeolian sand & Snail & -5.2 & 3305 & 25 & 3520 & 60 \\
\hline WW10707 & 172,815 & SRI-140-D middle & Lowermost paleosol in Holocene aeolian sand & Snail & -6.4 & 2865 & 30 & 2980 & 100 \\
\hline \multicolumn{10}{|c|}{ Coati Point $\left(\mathrm{N} 34^{\circ} 01.859^{\prime} ; \mathrm{W} 120^{\circ} 02.714^{\prime}\right)$} \\
\hline WW10710 & 172,818 & SRI-2-I/J & Between thin paleosols in aeolian sand, $10.2 \mathrm{~m}$ depth & Snail & -6.2 & 42,790 & 700 & 46,150 & 1380 \\
\hline WW10709 & 172,817 & SRI-2-C/D & In aeolian sand above marine deposits, $12.5 \mathrm{~m}$ depth & Snail & -8.7 & 42,580 & 690 & 45,930 & 1330 \\
\hline
\end{tabular}

${ }^{a}$ The USGS number is the identification assigned to a sample by the USGS ${ }^{14} \mathrm{C}$ laboratory in Reston, VA; the CAMS number is the identification assigned by the Center for Accelerator Mass Spectrometry in Livermore, CA.

${ }^{\mathrm{b}}$ Values reported for $\delta^{13} \mathrm{C}$ are the assumed values according to Stuiver and Polach (Radiocarbon, v.19, p. 355, 1977) when given without decimal places. Values measured for the material itself are given with a single decimal place.

${ }^{\mathrm{c}}$ Radiocarbon $\left({ }^{14} \mathrm{C}\right.$ ) ages are given in years before present (yr BP) with 1-sigma uncertainties following the conventions of Stuiver and Polach (1977).

d Calibrated ages were calculated using CALIB 7.1 software (Stuiver and Reimer 1993) in conjunction with the INTCAL13 atmospheric data set (Reimer et al. 2013). Values are the

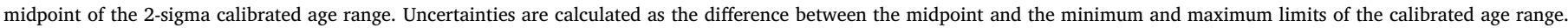

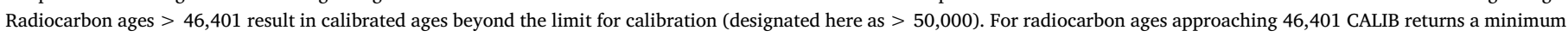
calibrated age, but not a maximum (designated here as greater or equal to the minimum calibrated age). All values are rounded to the nearest 10 years.

stabilization no later than $\sim 35,000 \mathrm{yr}$, and pedogenesis, represented by the Simonton soil II, continuing until at least $\sim 26,000 \mathrm{yr}$.

We have generally more consistent OSL and IRSL age estimates from the Yardang aeolianite above Simonton soil II. Approximately $16.5 \mathrm{~m}$ below the top of the Midden soil (SMI-5), in the lowermost crossbedded Yardang aeolianite, the multigrain OSL age is scattered and single-grain OSL analyses give a FMM (youngest) age of $27,000 \pm 2000 \mathrm{yr}$, with additional grain components of very old ages, indicating that some of the aeolian sand at this depth could be reworked from the underlying aeolian units. From this point upwards within the Yardang aeolianite, this reworking of older aeolian sand is not apparent. The quartz OSL analyses, indicating the best bleached grains, 
(a)

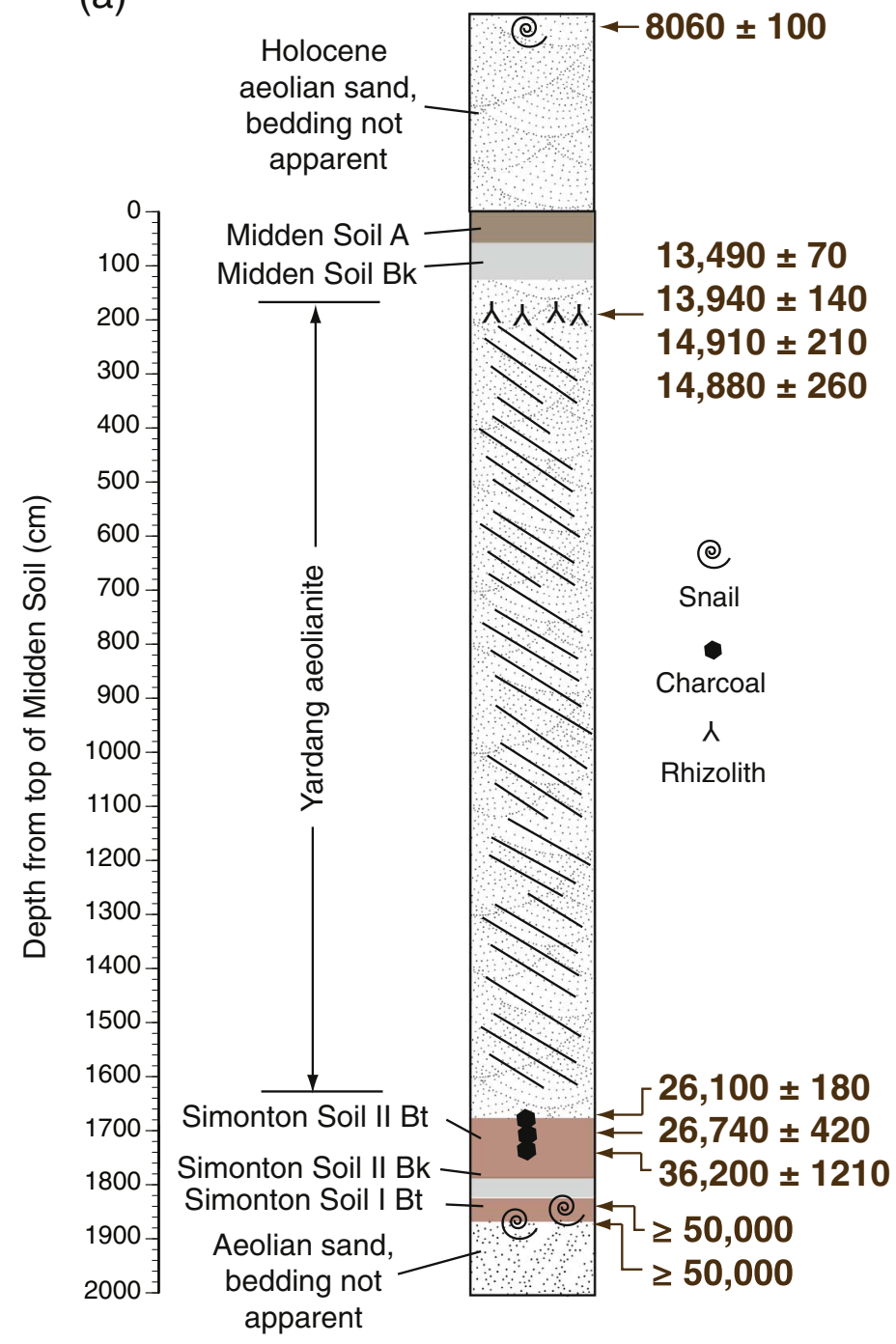

(b)

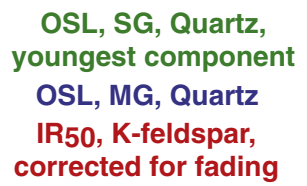

OSL, SG, Quartz, youngest component OSL, MG, Quartz

IR50, K-feldspar, corrected for fading

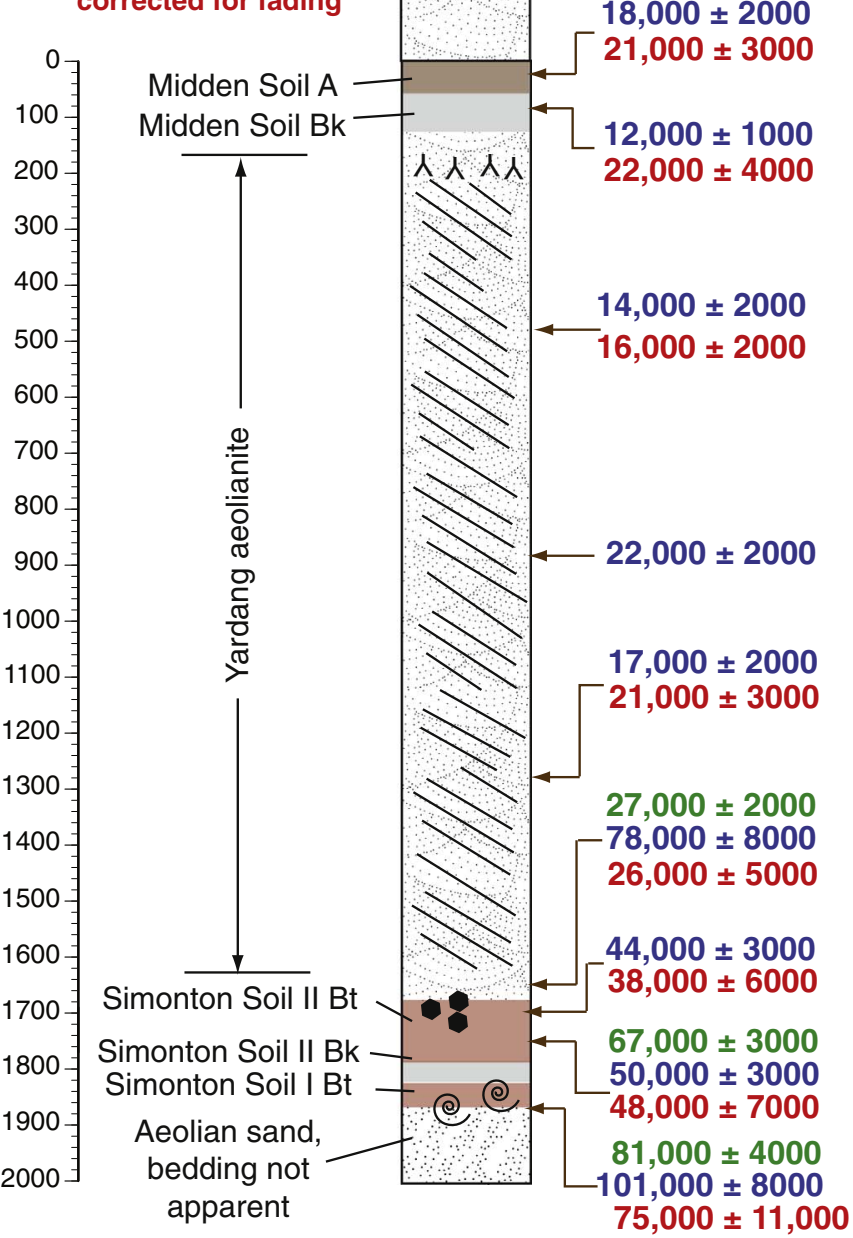

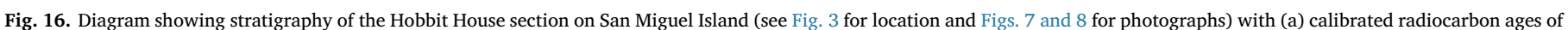
land snails, charcoal, and rhizoliths (Table 1), along with (b) luminescence ages (from Table 2).

for the four samples between $16.5 \mathrm{~m}$ and $4.8 \mathrm{~m}$ depth (SMI-5, SMI-6, SMI-7, and SMI-8, from lowest to highest) below the Midden soil, give an age range of $27,000 \pm 2000 \mathrm{yr}$ (SMI-5 at $16.5 \mathrm{~m}$ ) to $14,000 \pm 2000 \mathrm{yr}$ (SMI-8 at $4.8 \mathrm{~m}$ ) for the deposition of this sand unit, with a corresponding $\mathrm{IR}_{50}$ age range of $26,000 \pm 5000 \mathrm{yr}$ (SMI-5) to $16,000 \pm 2000 \mathrm{yr}$ (SMI-8). The ages of the two samples from the Midden soil also vary by method and mineral, but the quartz ages $(12,000 \pm 1000 \mathrm{yr}$ multigrain [SMI-10] and $7200 \pm 600 \mathrm{yr}$ FMM, youngest component [SMI-9]) are consistent with rhizolith radiocarbon ages $\sim 15,000$ to $\sim 13,500 \mathrm{yr}$.

\section{Aeolianite and aeolian sand on Santa Rosa Island}

\subsection{Distribution of aeolian deposits on Santa Rosa Island}

The mapping units we recognize on Santa Rosa Island are identical to those on San Miguel Island. The oldest aeolianite (Qeo) has thicknesses of at least $\sim 12 \mathrm{~m}$ and is characterized by well-developed "Green Mountain" soils in its upper part. This unit is found on stable, flat interfluves that are underlain by pre-last-interglacial marine terrace deposits, primarily in an area to the south and west of Carrington Point (Figs. 18, 19). Smaller areas of this unit are also mapped near Skunk Point and a few kilometers to the southeast of Sandy Point. With the exception of sea cliffs on the northern coast of Santa Rosa Island (Fig. 20), exposures of the Qeo unit are rare and its distribution is defined to a great extent by the presence of Green Mountain soils. It is likely that Holocene sand dunes obscure much of the distribution of Qeo, so it is possible that the unit is more widespread than that shown on Figure 18. The age of the Qeo unit is unknown, but as on San Miguel Island, it is found only on higher, older terraces of pre-last-interglacial age (Figs. 18, 19, 20).

The Qes unit on Santa Rosa Island is younger than Qeo and is found primarily to the east of Sandy Point, in the western part of the island (Fig. 19). This area is known locally as "Pocket Field" and is characterized, unfortunately, by few exposures. It can be inferred that the unit is younger than Qeo, however, by the fact that the soils are less well developed than the Green Mountain soils. In aeolian sands of the Qes unit, soils are characterized by strong brown to yellowish-brown $\mathrm{Bt}$ horizons underlain by Bk horizons that often form well-developed laminar calcretes. As on San Miguel Island, soils developed in unit Qes on Santa Rosa Island lack the pisoliths that characterize the Green Mountain soil developed in unit Qeo. Qes is found on pre-last-interglacial marine terraces, thus permitting (but not requiring) an interpretation that it is older than $\sim 120,000 \mathrm{yr}$.

The youngest Pleistocene aeolian sand and aeolianite unit on Santa Rosa Island is Qey, which consists of windblown sand, cemented or 

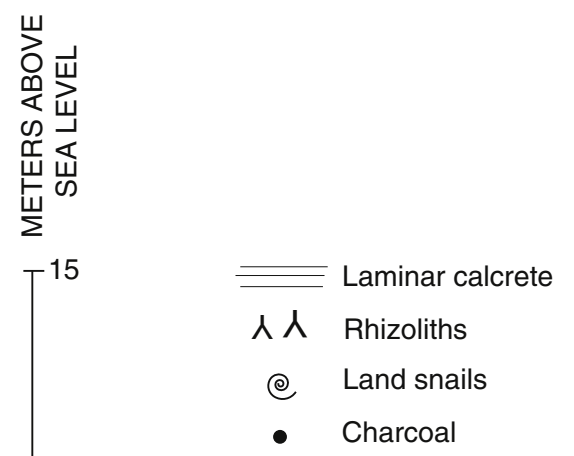

$-10$

$\underbrace{-10}_{0}$
20

\section{level}

10 METERS

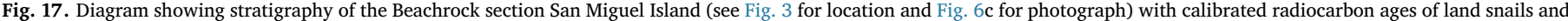
charcoal (taken from Table 1).

uncemented, overlying either $\sim 80,000$-yr-old or $\sim 120,000$ yr-old marine terrace deposits. These deposits are found around Sandy Point, intermittently along the north coast of the island, around Carrington Point and to the south of it, and in a coastal strip along Bechers Bay (Figs. 18, 21, 22). In the western and northern parts of the island, the unit is as much as $\sim 10 \mathrm{~m}$ thick where it overlies the $\sim 80,000$-yr-old marine terrace, although thicknesses of 4-6 m are more common (Fig. 23a). Skeletal sands are weakly cemented in this unit, much less so than is the case in the Qeo unit. Soils developed in the upper parts of the unit are characterized by prominent, reddish-brown Bt horizons underlain by Bk horizons (laminar calcretes), very similar to the Qes unit. Rhizoliths are common in the upper parts of this unit and sometimes occur throughout it, possibly indicating slow accretion under a vegetation cover. In the western and northern parts of the island, the Qey aeolianite is sometimes overlain by a few meters of brown or reddishbrown, clayey alluvium. Around Bechers Bay, the Qey unit overlies what Muhs et al. $(2014,2015)$ inferred is a marine terrace dating to either the $\sim 120,000 \mathrm{yr}$ or $\sim 100,000 \mathrm{yr}$ high-sea stand (Figs. 21, 22). Thicknesses of Qey here range from 6 to $14 \mathrm{~m}$, and bedding is usually horizontal, with weak or no cementation. Soils in the upper part of Qey around Bechers Bay have reddish-brown Bt and laminar calcrete Bk horizons, as is the case farther west, or simply have dark A horizons underlain by B horizons characterized by clay lamellae. In the western part of Santa Rosa Island, Qey is much more carbonate-rich and contains calcretes and rhizoliths (Fig. 23a).

As noted above for San Miguel Island, the Qes unit is mapped on terraces older than $\sim 120,000 \mathrm{yr}$ whereas the Qey unit is mapped on the $\sim 120,000 \mathrm{yr}$ and $\sim 80,000 \mathrm{yr}$ terraces. However, the similar degree of soil development (reddish brown Bt horizons underlain by laminar calcrete Bk horizons) in both the Qes and Qey units would permit an interpretation that the two units are of similar age. Thus, it is possible that on Santa Rosa Island, as on San Miguel Island, Qes is simply an inland facies of Qey.

Finally, Holocene aeolian sand is found in places on Santa Rosa Island. The sand, expressed as vegetated linear dunes (Fig. 19), is found overlying the Qeo unit in the Carrington Point area. A Holocene age is inferred for this unit because it has minimally developed soils with A/ $\mathrm{AC} / \mathrm{C}$ profiles and is the host sediment for midden deposits. Similar dunes overlie parts of the Qey unit along the northern, western, and southwestern coasts of the island. Partially stabilized Holocene aeolian sand is also present as small coppice dunes along the modern beach in Southeast Anchorage. Paleosols within the Holocene dunes indicate that aeolian sedimentation was episodic (Fig. 23b).

\subsection{Stratigraphy and geochronology of aeolian sand on Santa Rosa Island}

The oldest aeolian sand unit (Qeo) on Santa Rosa Island that we have observed is a 12.6-meter-thick aeolianite section (SRI-126) exposed to the west of Carrington Point (Figs. 18, 19, 20). A wave-eroded bench, without overlying marine deposits, is cut on the Miocene Beechers Bay Member of the Monterey Formation and has an elevation of $\sim 95 \mathrm{~m}$ above sea level. A paleosol developed in the Beechers Bay Member is overlain by at least $4 \mathrm{~m}$ of what we interpret to be aeolian sand, but bedding is not well exposed. A paleosol with a Bw horizon $30-40 \mathrm{~cm}$ thick has developed in these sands, which is in turn overlain by cemented aeolianite with very well-preserved bedding (Fig. 20). Sands in the lower $8 \mathrm{~m}$ of this aeolianite have beds, interpreted to be foresets, dipping $26^{\circ}$ to $34^{\circ}$ to the south-southeast. The foreset beds are overlain by sands with lower-angle dips $\left(\sim 1^{\circ}\right.$ to $\left.\sim 11^{\circ}\right)$, mostly to the northwest, interpreted to be topset beds. With foresets dipping southsoutheast and topsets dipping northwest, paleowinds are inferred to be from the northwest. The uppermost part of the unit is capped by a stripped Green Mountain soil (Fig. 23b), with rhizoliths and possible tree trunks in its lower part, and clay-filled solution pipes and Fe- 
Table 2

Optically stimulated luminescence (OSL) ages of quartz and infrared stimulated luminescence (IRSL) ages of K-feldspar (KF).

Numbers in bold are IR50 K-feldspar ages corrected for fading, considered to be the best overall age estimates.

\begin{tabular}{llllllllllllll}
\hline Mineral Lab code/technique & Depth & $\begin{array}{l}\text { Water } \\
\text { content }\end{array}$ & $\mathrm{K}$ & $\mathrm{U}$ & Th & Ext. $\alpha$ & Ext. $\beta$ & Ext. $\gamma$ & Cosmic & Total dose & $\begin{array}{l}\text { Aliquots } \\
\text { used }\end{array}$ & O-D De & Age
\end{tabular}

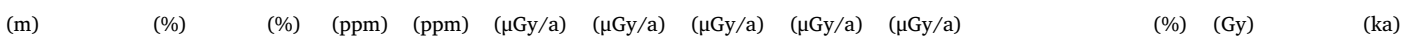

\begin{tabular}{|c|c|c|c|c|c|c|c|c|c|c|c|c|c|c|c|}
\hline & SMI-11 & & & & & & & & & & & & & & \\
\hline \multirow[t]{2}{*}{ Quartz } & MG & $\begin{array}{l}0.05 \\
\text { Modern }\end{array}$ & 10 & 1.49 & 8.8 & 2.6 & 19 & 1996 & 1329 & 264 & $3608 \pm 97$ & $10 / 11$ & 55 & $0.06 \pm 0.07$ & $\sim 15 \mathrm{yrs}$ \\
\hline & SMI-9 & & & & & & & & & & & & & & \\
\hline Quartz & MG & 0.2 & 10 & 0.83 & 0.9 & 2.8 & 3 & 678 & 392 & 210 & $1284 \pm 32$ & $19 / 19$ & 36 & $23 \pm 2$ & $18 \pm 2$ \\
\hline Quartz & SG1 & Midden & & & & & & & & & & $50 \%$ & 63 & $23 \pm 1$ & $18 \pm 1$ \\
\hline Quartz & SG2 & Soil, & & & & & & & & & & $31 \%$ & & $9.2 \pm 0.7$ & $7.2 \pm 0.6$ \\
\hline KF & pIR-IR 290 & Upper & & & & & 62 & 701 & & & $1821 \pm 62$ & $6 / 6$ & 20 & $53 \pm 5$ & $29 \pm 3$ \\
\hline KF & $\mathrm{IR}_{50}$ & & & & & & & & & & & $6 / 6$ & 21 & $30 \pm 2$ & $16 \pm 1$ \\
\hline KF & $\begin{array}{l}\mathrm{IR}_{50} \text {, corrected } \\
\text { SMI-10 }\end{array}$ & & & & & & & & & & & & & & $21 \pm 3$ \\
\hline Quartz & MG & 0.8 & 10 & 0.83 & 1.0 & 2.9 & 3 & 692 & 406 & 190 & $1292 \pm 50$ & $17 / 19$ & 54 & $15 \pm 1$ & $12 \pm 1$ \\
\hline $\mathrm{KF}$ & pIR-IR 290 & Midden & & & & & & & & & & $7 / 7$ & 16 & $51 \pm 3$ & $28 \pm 2$ \\
\hline KF & $\mathrm{IR}_{50}$ & Soil, & & & & & 74 & 715 & & & $1842 \pm 70$ & $7 / 7$ & 24 & $31 \pm 3$ & $17 \pm 2$ \\
\hline KF & $\begin{array}{l}\mathrm{IR}_{50} \text {, corrected } \\
\text { SMI-8 }\end{array}$ & Lower & & & & & & & & & & & & & $22 \pm 4$ \\
\hline Quartz & MG & 4.8 & 10 & 0.91 & 0.9 & 1.6 & 3 & 207 & 358 & 137 & $1200 \pm 39$ & $19 / 19$ & 51 & $16 \pm 2$ & $14 \pm 2$ \\
\hline $\mathrm{KF}$ & pIR-IR 290 & Yardang & & & & & & & & & & $9 / 9$ & 6 & $39 \pm 1$ & $23 \pm 1$ \\
\hline KF & $\mathrm{IR}_{50}$ & Aeolianite, & & & & & 50 & 726 & & & $1726 \pm 61$ & $9 / 9$ & 12 & $21 \pm 1$ & $12 \pm 1$ \\
\hline KF & $\begin{array}{l}\mathrm{IR}_{50} \text {, corrected } \\
\text { SMI-7 }\end{array}$ & Upper & & & & & & & & & & & & & $16 \pm 2$ \\
\hline \multirow[t]{3}{*}{ Quartz } & MG & 8.8 & 10 & 0.50 & 0.6 & 0.8 & 2 & 396 & 204 & 89 & $691 \pm 34$ & $18 / 19$ & 47 & $15 \pm 1$ & $22 \pm 2$ \\
\hline & & $\begin{array}{l}\text { Yardang } \\
\text { Aeolianite, } \\
\text { Upper- } \\
\text { Middle }\end{array}$ & & & & & & & & & & & & & \\
\hline & SMI-6 & & & & & & & & & & & & & & \\
\hline Quartz & MG & 12.8 & 10 & 0.83 & 0.7 & 1.2 & 2 & 621 & 303 & 62 & $988 \pm 36$ & $19 / 19$ & 45 & $17 \pm 2$ & $17 \pm 2$ \\
\hline $\mathrm{KF}$ & pIR-IR 290 & Yardang & & & & & & & & & & $9 / 9$ & 9 & $43 \pm 2$ & $29 \pm 2$ \\
\hline $\mathrm{KF}$ & $\mathrm{IR}_{50}$ & Aeolianite, & & & & & 39 & 642 & & & $1501 \pm 59$ & $9 / 9$ & 9 & $24 \pm 1$ & $16 \pm 1$ \\
\hline \multirow[t]{2}{*}{ KF } & $\mathrm{IR}_{50}$, corrected & $\begin{array}{l}\text { Lower- } \\
\text { Middle }\end{array}$ & & & & & & & & & & & & & $21 \pm 3$ \\
\hline & SMI-5 & & & & & & & & & & & & & & \\
\hline Quartz & MG & 16.5 & 10 & 0.75 & 0.6 & 1.3 & 2 & 562 & 280 & 46 & $890 \pm 24$ & $17 / 17$ & 41 & $70 \pm 7$ & $78 \pm 8$ \\
\hline Quartz & SG1 & Yardang & & & & & & & & & & $50 \%$ & 90 & $24 \pm 2$ & $27 \pm 2$ \\
\hline Quartz & SG2 & Aeolianite, & & & & & & & & & & $11 \%$ & & $156 \pm 7$ & $176 \pm 10$ \\
\hline $\mathrm{KF}$ & pIR-IR 290 & Lower & & & & & 36 & 581 & & & $1398 \pm 52$ & $6 / 8$ & 27 & $40 \pm 2$ & $33 \pm 2$ \\
\hline $\mathrm{KF}$ & $\mathrm{IR}_{50}$ & & & & & & & & & & & $6 / 8$ & 28 & $28 \pm 2$ & $20 \pm 2$ \\
\hline KF & $\begin{array}{l}\mathrm{IR}_{50} \text {, corrected } \\
\text { SMI-4 }\end{array}$ & & & & & & & & & & & & & & $26 \pm 5$ \\
\hline Quartz & MG & 17 & 15 & 2.57 & 1.2 & 5.1 & 5 & 1743 & 856 & 44 & $2649 \pm 83$ & $14 / 14$ & 14 & $118 \pm 5$ & $44 \pm 3$ \\
\hline $\mathrm{KF}$ & pIR-IR 290 & Simonton & & & & & & & & & & $9 / 9$ & 13 & $114 \pm 5$ & $35 \pm 2$ \\
\hline KF & $\mathrm{IR}_{50}$ & Soil II & & & & & 91 & 1802 & & & $3248 \pm 99$ & $9 / 9$ & 13 & $95 \pm 5$ & $29 \pm 2$ \\
\hline KF & $\begin{array}{l}\mathrm{IR}_{50} \text {, corrected } \\
\text { SMI-3 }\end{array}$ & & & & & & & & & & & & & & $38 \pm 6$ \\
\hline Quartz & MG & 17.5 & 15 & 2.57 & 1.2 & 6.7 & 5 & 1776 & 921 & 43 & $2746 \pm 85$ & $13 / 13$ & 14 & $138 \pm 7$ & $50 \pm 3$ \\
\hline Quartz & SG1 & Simonton & & & & & & & & & & $44 \%$ & 43 & $183 \pm 6$ & $67 \pm 3$ \\
\hline Quartz & SG2 & Soil II & & & & & & & & & & $34 \%$ & & $112 \pm 5$ & $41 \pm 2$ \\
\hline $\mathrm{KF}$ & pIR-IR 290 & & & & & & 117 & 1836 & & & $3361 \pm 102$ & $9 / 9$ & 10 & $180 \pm 3$ & $54 \pm 2$ \\
\hline $\mathrm{KF}$ & $\mathrm{IR}_{50}$ & & & & & & & & & & & $9 / 9$ & 12 & $121 \pm 6$ & $36 \pm 2$ \\
\hline KF & $\begin{array}{l}\mathrm{IR}_{50} \text {, corrected } \\
\text { SMI-2 }\end{array}$ & & & & & & & & & & & & & & $48 \pm 7$ \\
\hline Quartz & MG & 18.2 & 15 & 1.91 & 0.8 & 4.0 & 3 & 1290 & 636 & 40 & $1970 \pm 62$ & $17 / 17$ & 29 & $199 \pm 15$ & $101 \pm 8$ \\
\hline Quartz & SG1 & Simonton & & & & & & & & & & $37 \%$ & 45 & $159 \pm 5$ & $81 \pm 4$ \\
\hline Quartz & SG2 & Soil I & & & & & & & & & & $14 \%$ & & $94 \pm 4$ & $48 \pm 3$ \\
\hline $\mathrm{KF}$ & pIR-IR 290 & & & & & & 66 & 1333 & & & $2531 \pm 79$ & $8 / 8$ & 12 & $160 \pm 7$ & $63 \pm 4$ \\
\hline KF & $\mathrm{IR}_{50}$ & & & & & & & & & & & $8 / 8$ & 13 & $143 \pm 7$ & $56 \pm 3$ \\
\hline KF & $\mathrm{IR}_{50}$, corrected & & & & & & & & & & & & & & $75 \pm 11$ \\
\hline
\end{tabular}

Notes:

Samples are arranged in stratigraphic order, from top to bottom. Burial depths are measured from the top of the Midden Soil.

SMI-11 - modern analog taken from Sandblast Pass.

Multi-grain (MG) measurements were carried out on 2-mm aliquots ( $\sim 150$ grains). SG - single grain measurements.

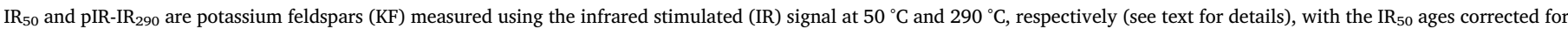
anomalous fading (marked "corrected" in second column).

De and errors were calculated using the Central Age Model (CAM).

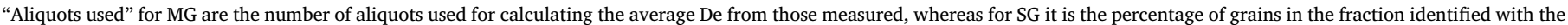
Finite Mixture Model (FMM; see main text for details). SG1 and SG2 are the most significant components identified using the FMM.

O-D - over-dispersion, a measure of the scatter in the sample. O-D values for SG are always higher than MG measurements.

Grain size for all samples - $125-150 \mu \mathrm{m}$.

Water contents were measured after returning from the field, giving values of 4-8\% for the sand and 13\% for the soil (SMI-12).

Due to the risk of drying during sample transport, moisture contents of $10 \pm 2 \%$ or $15 \pm 3 \%$ were used for the upper and lower samples, respectively.

Errors on the concentrations of $\mathrm{K}, \mathrm{U}$ and Th are $5 \%, 8 \%$ and $10 \%$ of the values, respectively. Note that dose rates differ for quartz and $\mathrm{KF}$.

KF were not etched. K-content was estimated at $12 \pm 0.5 \%$, giving an internal beta dose of $455 \pm 45 \mu \mathrm{Gy} / \mathrm{a}$ (not in table). The a-value was estimated at $0.09 \pm 0.02$. 
pisoliths in its upper part. This in turn is overlain by Holocene aeolian sand that we discuss below.

Unfortunately, in this entire section, no materials suitable for dating, such as snails or charcoal, could be found. Even the rhizoliths show evidence of secondary dissolution and reprecipitation. Our only basis for an age estimate for this unit is a maximum-limiting estimate based on the elevation of the underlying wave-cut bench. Muhs et al. (2014) reported that the 2nd emergent terrace on the northern coast of Santa Rosa Island has a shoreline angle elevation of $\sim 24 \mathrm{~m}$ and has been dated to $\sim 120,000 \mathrm{yr}$. If we assume a $+6 \mathrm{~m}$ paleo-sea level at the time of terrace formation at $\sim 120,000 \mathrm{yr}$, this yields a late Quaternary uplift rate of $0.15 \mathrm{~m} / 1000 \mathrm{yr}$. With an outer edge of $\sim 95 \mathrm{~m}$, the wavecut bench underlying the aeolianite west of Carrington Point could be at least as old as $\sim 650,000-600,000 \mathrm{yr}$, if we extrapolate this uplift rate back in time. The aeolianite overlying the wave-cut bench must be younger than this maximum-limiting age.

The Qey unit is found around the margins of the island, overlying marine terraces of the last interglacial complex, but its stratigraphy and sedimentology differ considerably from location to location. To the south of Carrrington Point, near Coati Point, coastal sections of falling dunes are exposed along the northwestern margins of Bechers Bay (Figs. 19, 21). Falling dunes have not been previously reported as such on the Channel Islands and therefore a brief description of their origins is given here.

When aeolian sand in transit encounters a major topographic obstacle, such as a sea cliff or a mountain front, but where winds are sufficiently strong, sand can be deposited on the obstructing slope, creating a landform called a "climbing dune" or "sand ramp," as they are called in the Mojave Desert (Lancaster and Tchakerian 1996). Climbing dunes composed of carbonate aeolian sand, underlain by older aeolianite, are also well exposed at Groper Bay, South Australia (see Short 2014; his Figure 10). On the Channel Islands, a good example of a climbing dune is the modern, active dune derived from beach sands at Cuyler Harbor (Fig. 4). Inactive (stabilized) climbing dunes are also found on the northwestern coast of Santa Rosa Island, a short distance to the northeast of Sandy Point (Fig. 19b). If winds are sufficiently strong that some aeolian sand can be transported over the topographic obstacle and deposited on the leeward side, the resulting landform is called a "falling dune" (also called a sand ramp). Good examples of dissected, but inactive falling dunes are found to the southeast of Sandy Point in northwestern Santa Rosa Island (Fig. 19b). Because both climbing and falling dunes occur on slopes, aeolian sands within them are often interbedded with colluvially derived coarser clasts, including fragments of bedrock, calcrete or other materials eroded from upslope.

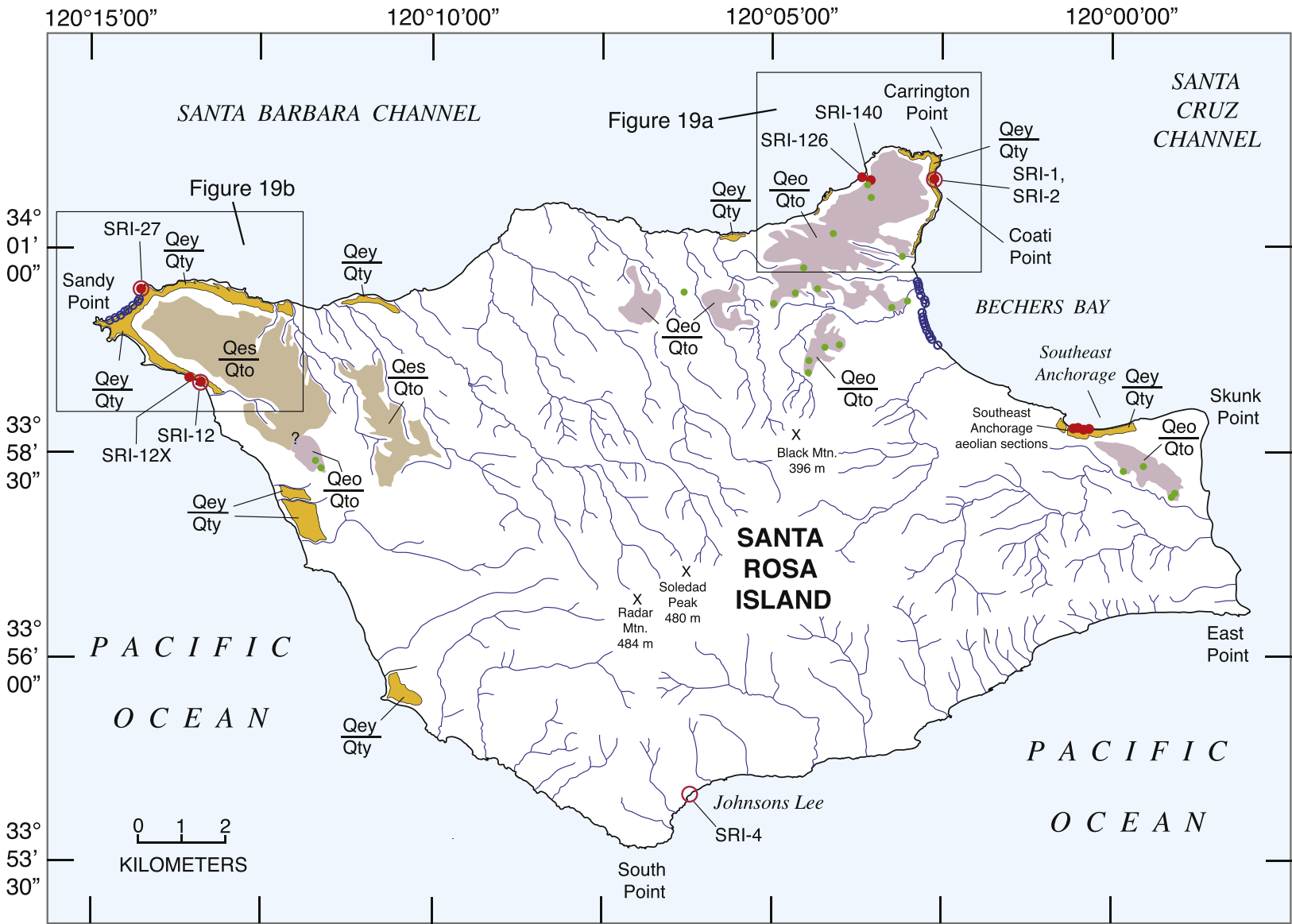

Qey/Qty Historic or Holocene (Qeh) and/or late Quaternary aeolianite or aeolian sand (Qey) over last interglacial marine terrace complex deposits (Qty)

Qes/Qto Historic or Holocene (Qeh) and/or undifferentiated Quaternary aeolianite or aeolian sand (Qes) over pre-last interglacial marine terrace deposits (Qto)

Qeo/Qto

Historic or Holocene (Qeh) and/or undifferentiated Quaternary aeolianite or aeolian sand (Qes) over pre-late Quaternary aeolianite (Qeo) with Green Mountain soil in its upper part, all overlying pre-last interglacial marine terrace deposits (Qto)

$$
\begin{array}{cccc}
\text { - Green Mountain } \\
\text { soil observed }
\end{array} \begin{gathered}
\text { Aeolian sand/aeolianite } \\
\text { section studied }
\end{gathered} \quad \begin{gathered}
\text { Modern beach } \\
\text { sand collected }
\end{gathered} \begin{gathered}
\bigcirc \\
\text { SRI-4 }
\end{gathered}
$$

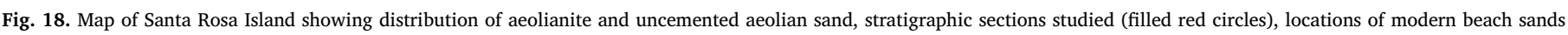

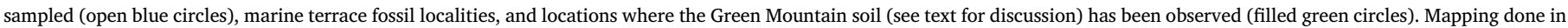

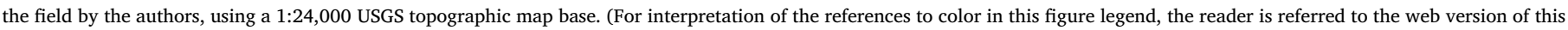
article.) 
$120^{\circ} 05^{\prime} 00^{\prime}$

(a)

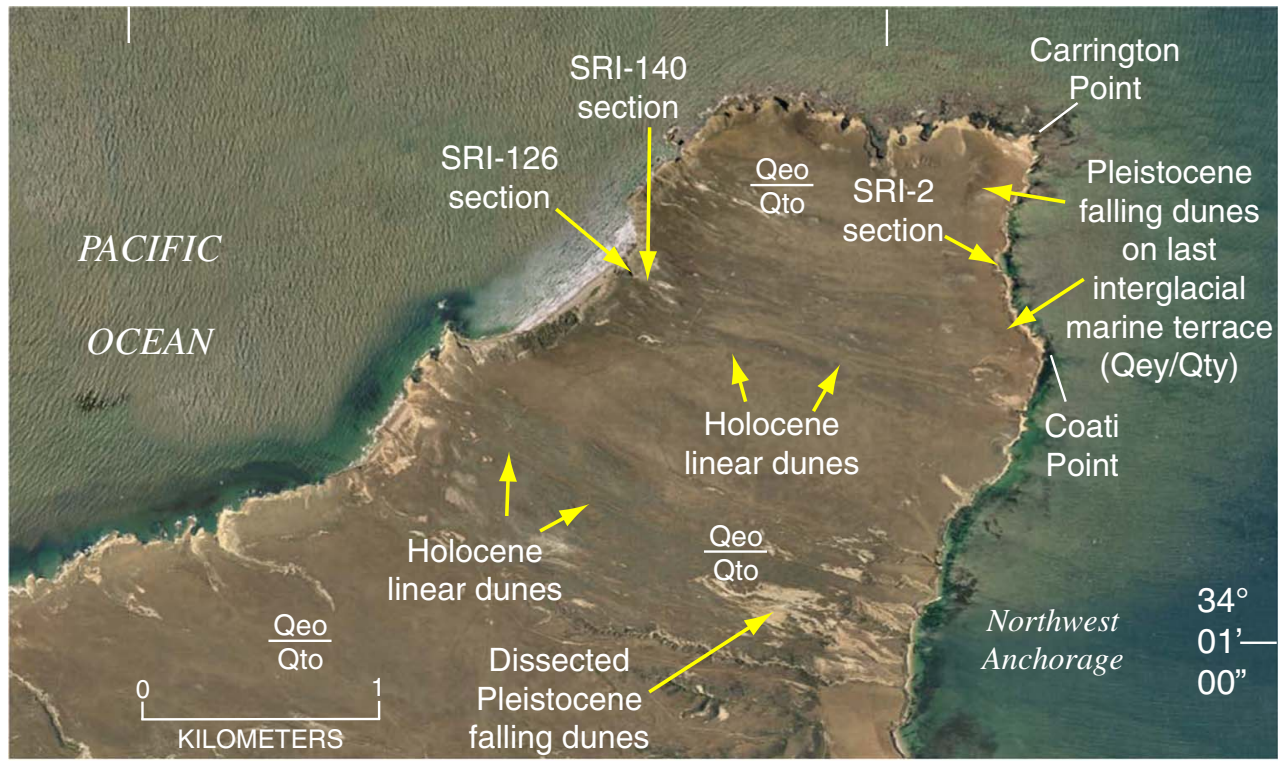

Fig. 19. (a) True-color aerial photograph (acquired 2002) of the Carrington Point area of Santa Rosa Island, showing location of aeolian sections and geomorphology (Holocene linear dunes and Pleistocene falling dunes). (b) True-color aerial photograph (acquired in 2002) showing localities referenced in text and geomorphology of aeolian deposits on the westernmost end of Santa Rosa Island.

Photos courtesy of the National Park Service.

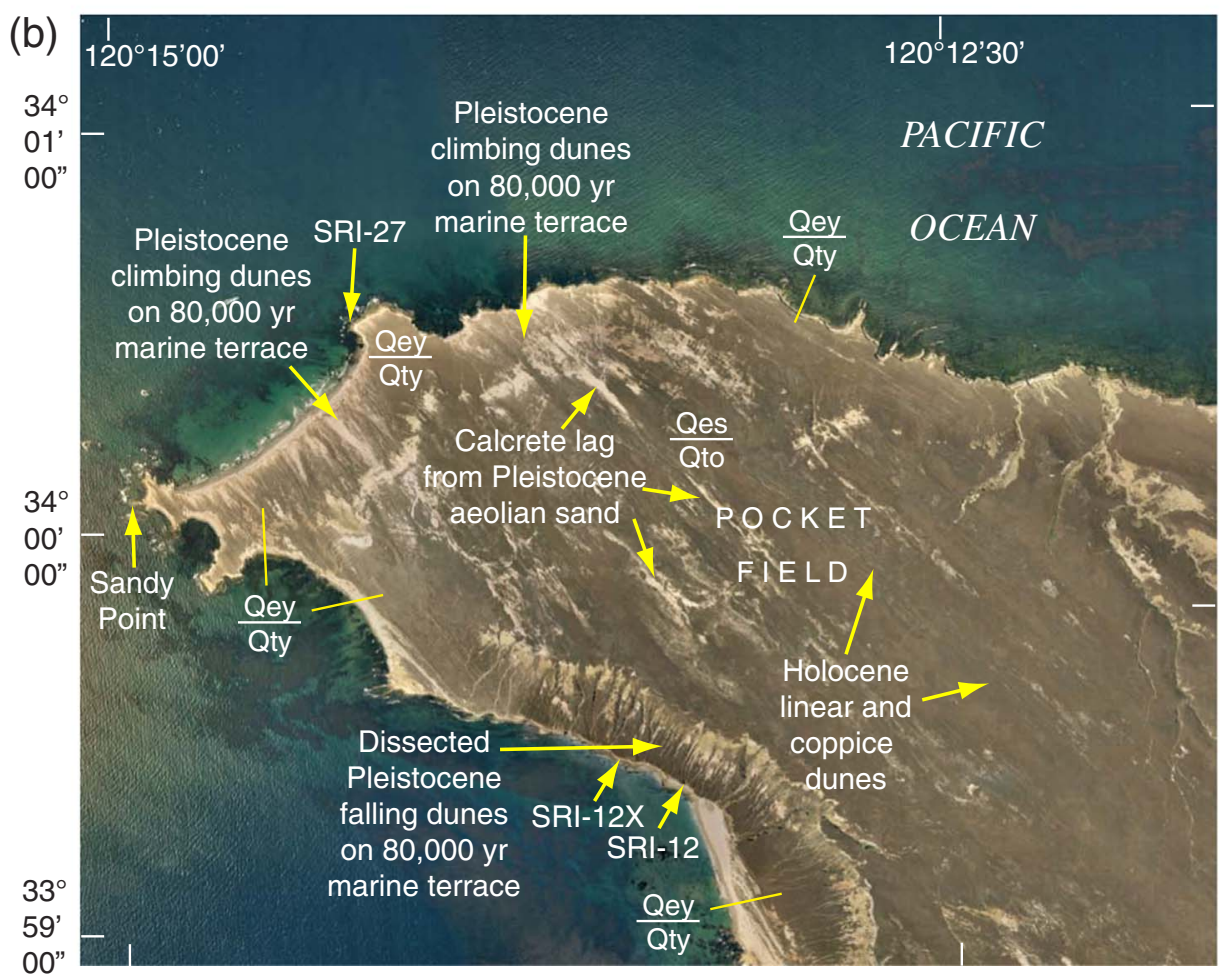

One of the sections exposed within a falling dune is near Coati Point (SRI-1 in Muhs et al. 2014; SRI-2 in Fig. 18) where $\sim 15 \mathrm{~m}$ of aeolian sand and aeolianite overlie coral-bearing marine terrace deposits (Fig. 21a). Corals from the marine terrace deposit below the aeolian sand package yielded U-series ages of $\sim 113,000 \mathrm{yr}$ to $\sim 110,000 \mathrm{yr}$ (Muhs et al. 2015), indicating that the marine deposits could correlate with either the $\sim 120,000 \mathrm{yr}$ high-sea stand (MIS 5.5 ) or the $\sim 100,000$ yr high-sea stand (MIS 5.3). A paleosol is present in the upper part of the marine deposits and aeolian sands are found above this buried soil. Some of the aeolian deposits are bedded and some are cemented into aeolianite; other deposits are loose, unbedded sand. Pebble layers are found in some parts of the section, which is part of the basis for interpreting these otherwise well-sorted sands as part of a falling dune deposit. Falling dunes are often composed of aeolian sand interbedded with colluvium. Aeolian deposition was episodic since marine terrace emergence, as shown by the presence of paleosols (Fig. 21b).

It is difficult to determine the precise age of the aeolian sands at Coati Point, except that they post-date the peak of the last interglacial period (MIS 5.5) at $\sim 120,000 \mathrm{yr}$. Land snails were found at depths of $\sim 12.6 \mathrm{~m}$ and $\sim 10.2 \mathrm{~m}$, within and at the top of the oldest aeolianite, and both yielded calibrated radiocarbon ages of $\sim 46,000 \mathrm{yr}$ (Fig. 21b and Table 1). Because these apparent ages are at the practical limit of the radiocarbon dating technique, it is likely they are both older, as very small amounts of modern carbon contamination can yield apparently finite ages in a material that is beyond the limit of radiocarbon dating (Pigati et al. 2007). In any case, the lowest few meters of aeolian sand must be younger than $\sim 120,000$ yr (based on the U-series ages 
(a)

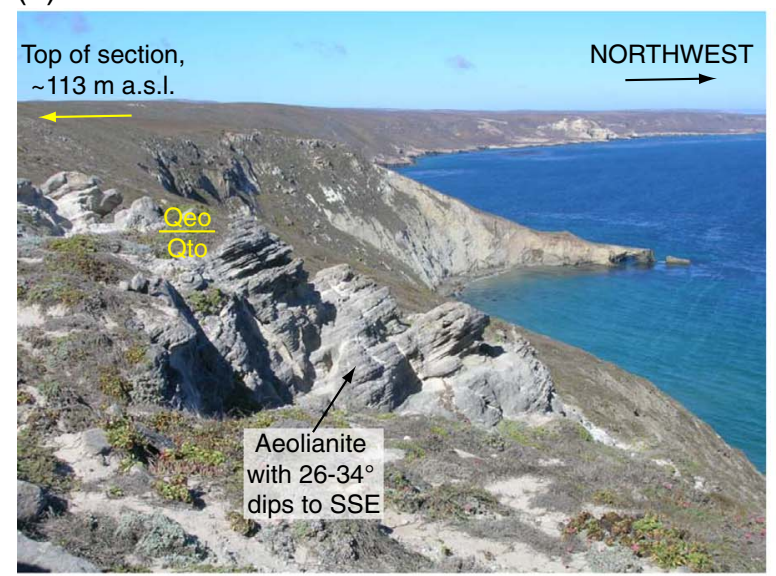

(c)

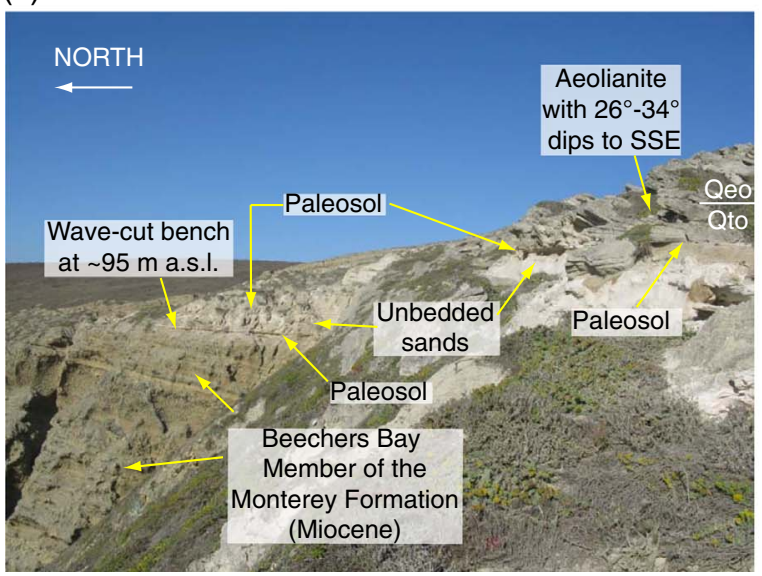

(b)

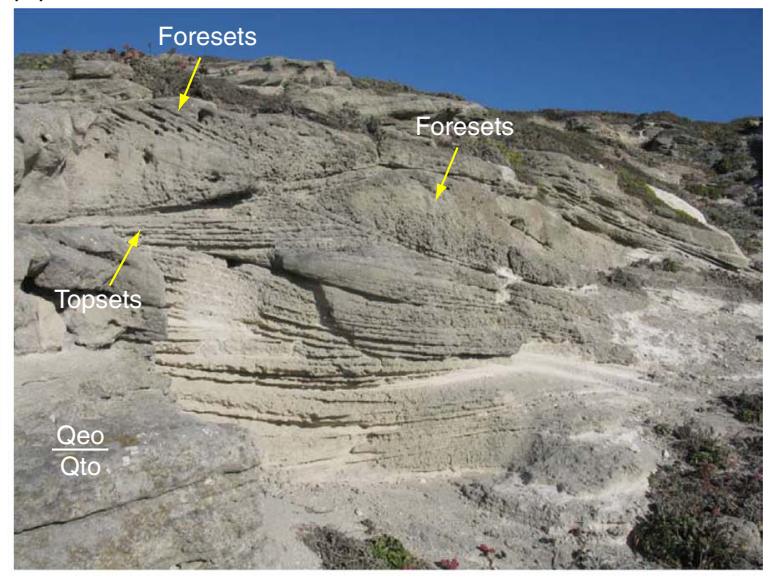

(d)

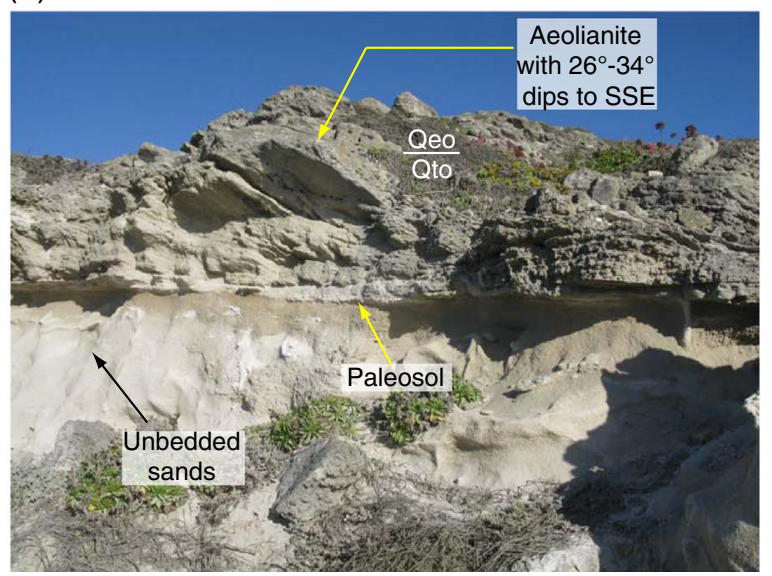

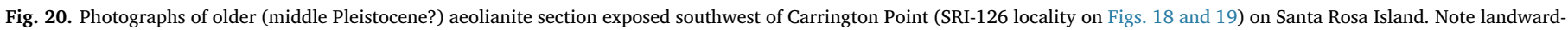
dipping high-angle foreset beds and lack of beach sources in (a).

All photos by D.R. Muhs.

discussed above) but no younger than $\sim 46,000 \mathrm{yr}$. The $\sim 10 \mathrm{~m}$ of aeolian sand above this could be younger than $\sim 46,000 \mathrm{yr}$, if we accept the radiocarbon ages of the snails. Based on degree of soil development, the longest period of stability recorded in the section at Coati Point appears to have been since the last episode of aeolian sand deposition (the upper $\sim 5 \mathrm{~m}$ of section). The modern soil in this part of the section is well developed and carbonate minerals (calcite and aragonite) have been largely leached away, other than in their accumulation in rhizoliths (Fig. 21b).

Aeolian sands are also exposed in cliff sections along Southeast Anchorage (Fig. 18). Here, aeolian sand is uncemented and ranges in thickness from $\sim 6$ to $\sim 11 \mathrm{~m}$ (Fig. 22), overlying marine terrace deposits that are thought to be correlative with those at SRI-1/SRI-2. The aeolian deposits are often unbedded, but at one locality, finely laminated beds, either horizontal or dipping gently seaward, are found. At two localities, well-developed soils with reddish-brown Bt horizons are found in the upper part of the aeolian sand and at the other two localities, clay lamellae are found below the A horizon of the modern soil. At the locality where bedded sand is found, in places horizontal beds are deformed in a manner suggesting the possibility of tracks left by a large mammal, such as Mammuthus (Fig. 22), similar to track prints in aeolianite described by Loope and Abegg (2001), Roberts et al. (2008), and Milàn et al. (2015). Because the youngest, reliably dated mammoth on Santa Rosa Island has a calibrated radiocarbon age of $\sim 12,900 \mathrm{yr}$ (Agenbroad 2005), we infer that the aeolian sand deposited around Southeast Anchorage is younger than $\sim 110,000 \mathrm{yr}$ (the youngest age of the marine terrace corals), but older than $\sim 12,900 \mathrm{yr}$. An age older than $\sim 12,900 \mathrm{yr}$ is consistent with the occurrence of the reddish-brown Bt horizons found in these units, which are better developed than soils we have seen in Holocene aeolian sands on Santa Rosa Island.

On the western part of Santa Rosa Island, carbonate-rich aeolianite overlies the 1st emergent marine terrace, which Muhs et al. (2015) dated to $\sim 80,000 \mathrm{yr}$ (MIS 5.1), based on five U-series ages of corals from locality SRI-27 (Figs. 18, 19). Here, relatively thin, but weakly cemented aeolianites form at least two units, separated by a soil Bk (calcrete) horizon (Fig. 23a). Radiocarbon ages of rhizoliths from these units differ little in age and are actually reversed relative to the stratigraphy, but imply that the start of aeolian sand stabilization took place around $\sim 29,000 \mathrm{yr}$ before present. The aeolian sand above the $\sim 80,000$-yr-old marine terrace deposits is overlain by a very well-developed soil with a reddish-brown Bt horizon that forms distinctive soil pipes (not visible in Fig. 23a). This soil is in turn overlain by $\sim 4 \mathrm{~m}$ of Holocene aeolian sand that contains four midden deposits. The secondoldest of these (2.85 m depth) contains sea urchin (Strongylocentrotus sp. [?]) plates that yielded a calibrated radiocarbon age of $5570 \pm 80 \mathrm{yr}$, confirming the Holocene age of the upper $\sim 4 \mathrm{~m}$ of the aeolian section. Thus, in this section, aeolian sand deposition took place between $\sim 80,000 \mathrm{yr}$ and $\sim 30,000 \mathrm{yr}$ and then again in the Holocene.

Holocene linear and coppice dunes are found on the northwestern part of Santa Rosa Island, along Southeast Anchorage, and south of Carrington Point (Figs. 18, 19). Southwest of Carrington Point at locality SRI-140, a short distance from SRI-126, what we interpret to be linear dunes of Holocene age are exposed in an interdune area (Fig. 23b). Orientations of the long axes of dunes in this area (Fig. 19a) 


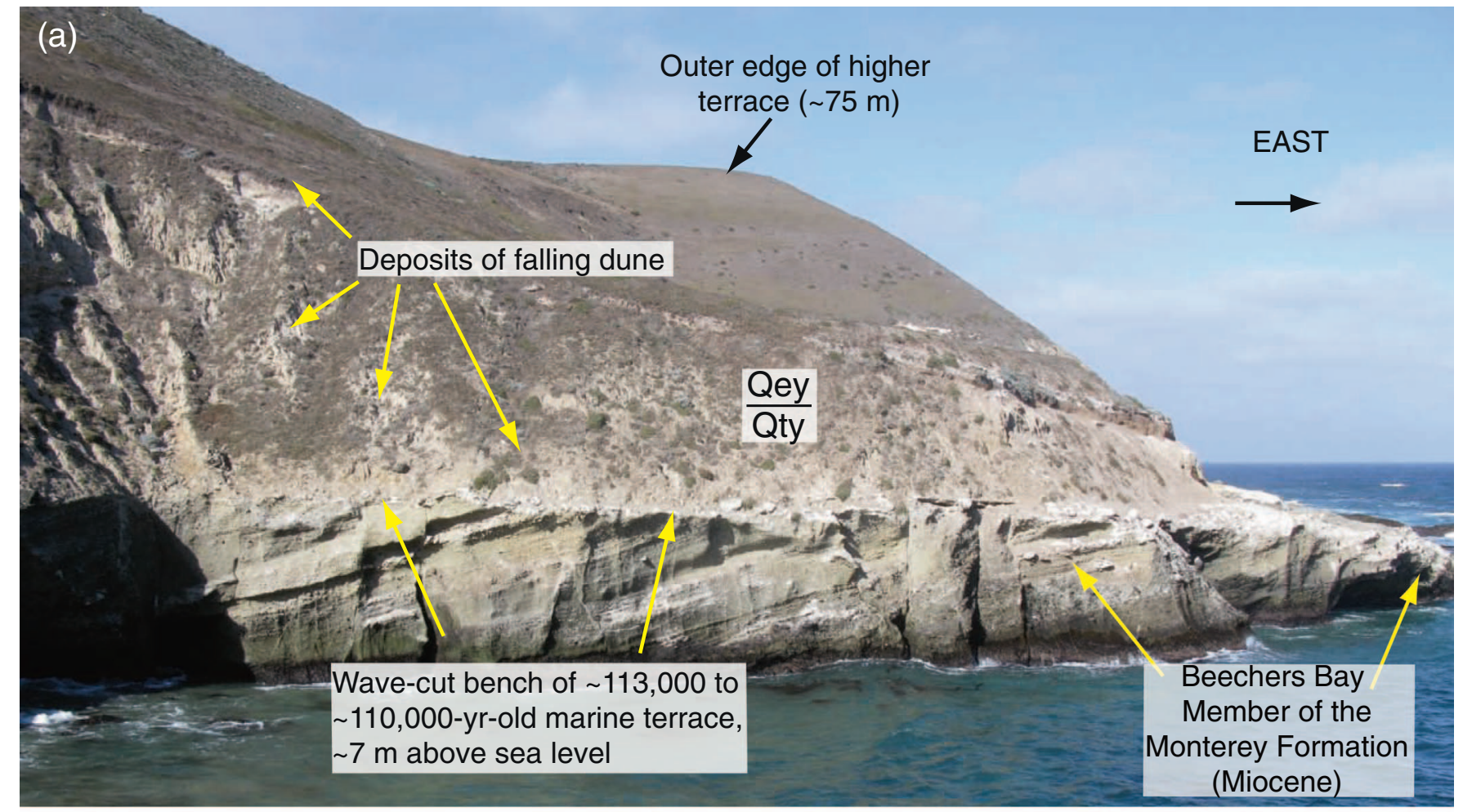

(b)

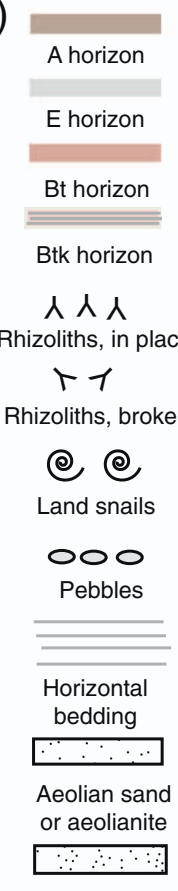

Marine terrace sand and shells

\section{Marine terrace sand, gravel, corals, and shells}

e) 8

Marine fossils

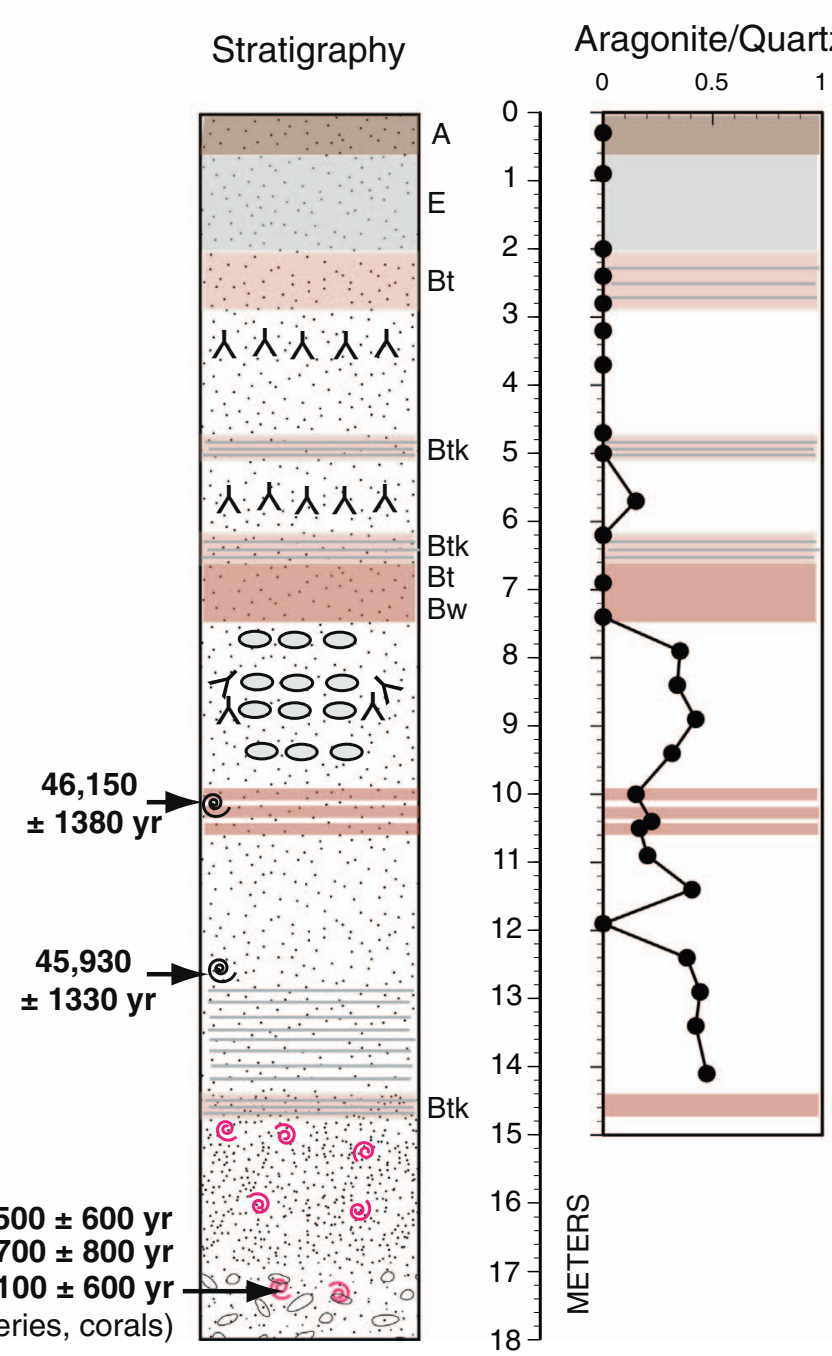

Calcite/Quartz

Total $\mathrm{CaCO}_{3}(\%)$
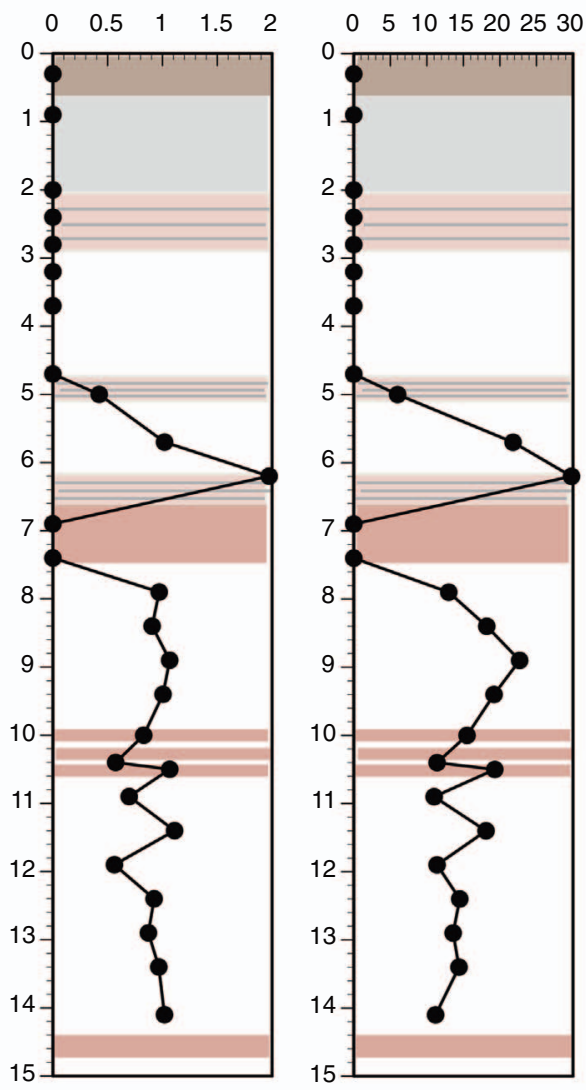


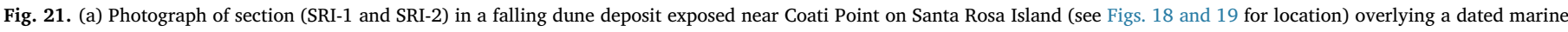

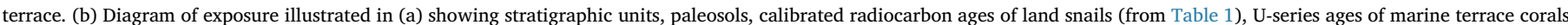

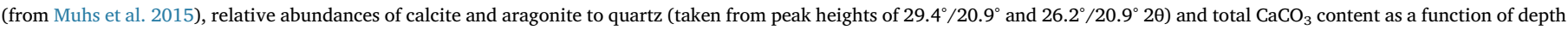
and stratigraphic unit.

indicate paleowinds from the west-northwest, similar to modern winds (Fig. 2b). Two paleosols are found within the exposure, which in total is only a few meters thick. Land snails in the lower paleosol yielded calibrated radiocarbon ages (Table 1) of $3520 \pm 60 \mathrm{yr}$ (WW10706) and $2980 \pm 100 \mathrm{yr}$ (WW10707); from the upper paleosol, a land snail gave a calibrated age of $610 \pm 60 \mathrm{yr}$ (WW10708). Thus, in this area, dunes were active during the late Holocene, and the youngest aeolian sand was apparently stabilized in just the past few centuries.

\subsection{Mineralogy of aeolian sand on Santa Rosa Island}

The mineralogy of beach and aeolian sand on Santa Rosa Island is quite variable. Modern beach sand at Bechers Bay contains quartz, plagioclase, calcite, K-feldspar (in most, but not all samples), and amphibole (in about half the samples). Aragonite was not detected in any of the modern beach samples from Bechers Bay and total $\mathrm{CaCO}_{3}$, apparently represented only by calcite, has a range of only $6-17 \%$. Modern beach sands at Sandy Point on Santa Rosa Island contain quartz, plagioclase, calcite, and aragonite, with K-feldspar in most samples. Total $\mathrm{CaCO}_{3}$ in these sands, including both calcite and aragonite, has a range of $10-22 \%$, still lower than that in beach sands on San Miguel Island, but higher than modern beach sand at Bechers Bay. Holocene aeolian sands (Qeh) at Sandy Point also have quartz, plagioclase, calcite and aragonite, and total $\mathrm{CaCO}_{3}$ (calcite and aragonite) has a range of $27-45 \%$, significantly higher than the local beach sand. The Pleistocene aeolian sand (Qey) at Sandy Point contains quartz, plagioclase, K-feldspar (most samples), calcite, and aragonite, with total $\mathrm{CaCO}_{3}$ content higher still, ranging from $\sim 42 \%$ to $\sim 68 \%$. Finally, the older aeolianite (Qeo) section at SRI-126, southwest of Carrington Point, has sands containing quartz, plagioclase, K-feldspar (most samples), and only calcite, without a trace of aragonite. Despite the lack of aragonite in this aeolianite, total $\mathrm{CaCO}_{3}$ is still relatively high, with a range of $32-49 \%$.

Overall, comparison of relative abundances of quartz, plagioclase, and calcite shows that, like San Miguel Island, both Holocene and Pleistocene aeolian sand at Sandy Point on Santa Rosa Island differ from local, modern beach sand in having a higher carbonate content (Fig. 24a, b). This is also the case with the older aeolianite at Carrington
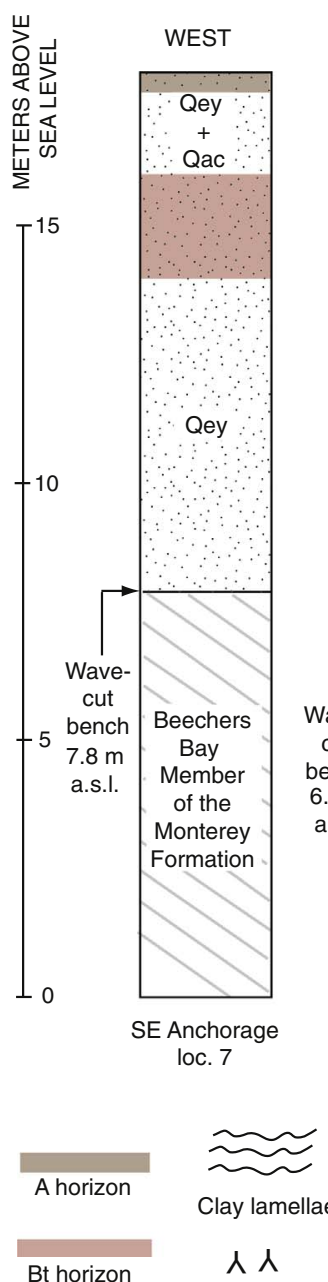

Clay lamellae

ᄉ (a)

(b)
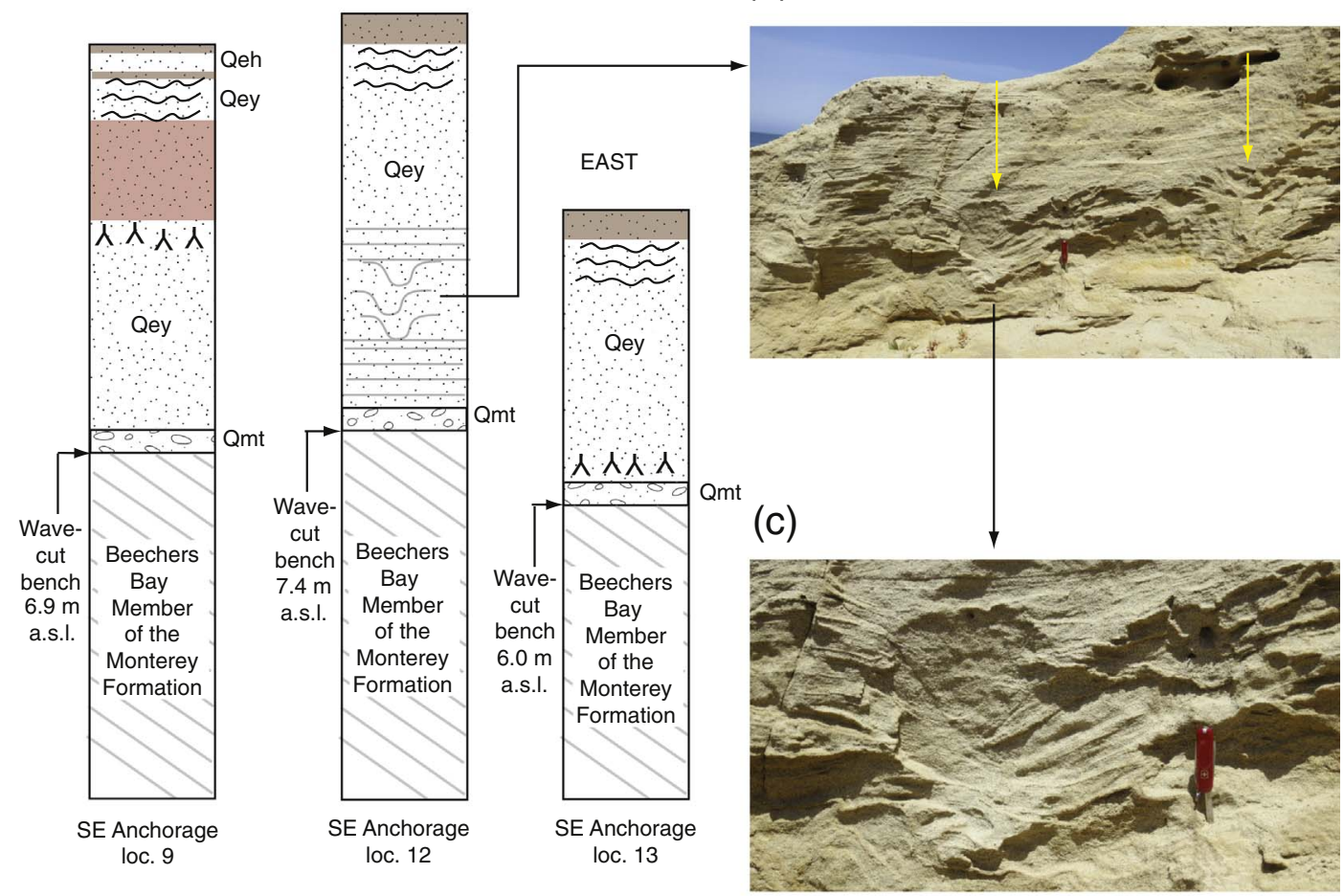

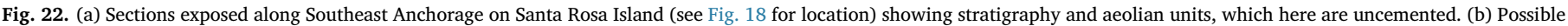
mammoth tracks (arrows) in aeolian sand in one of the sections shown in (a). (c) Enlargement of possible mammoth tracks shown in (b).

Photographs by D.R. Muhs. 


\section{(a) SRI-27 section}

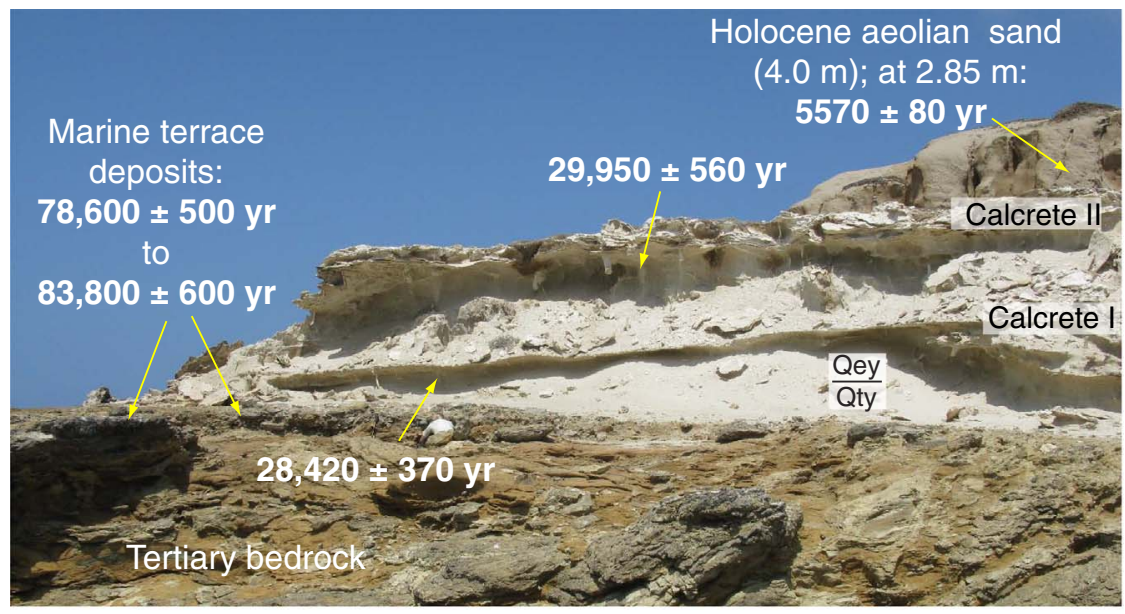

(b) SRI-140 section

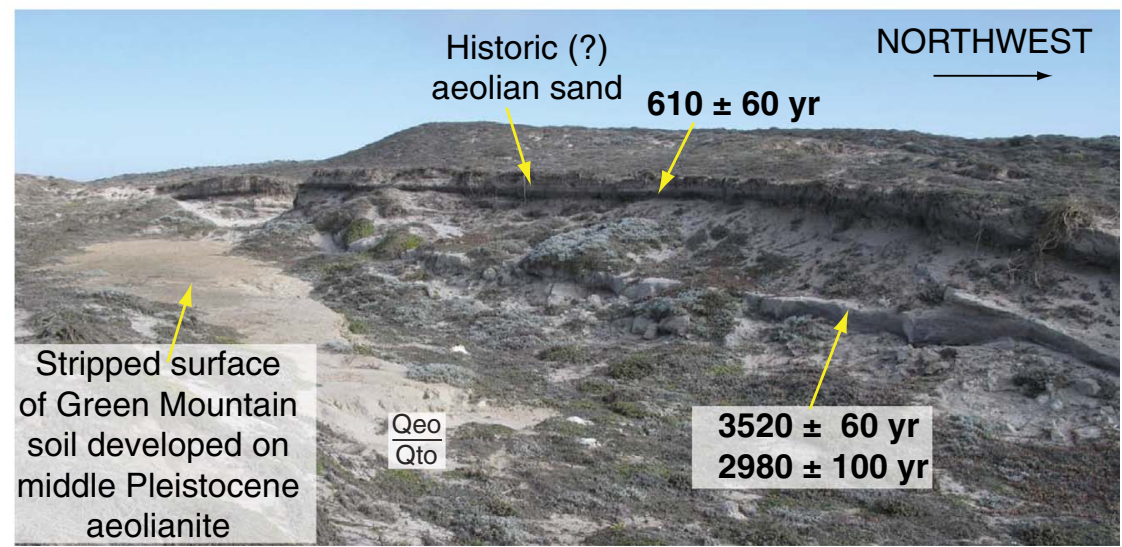

Fig. 23. (a) Photograph of late Quaternary aeolianite units overlying $\sim 80,000$-yr-old marine terrace deposits (U-series ages of marine terrace corals from Muhs et al. 2015) at the SRI-27 locality on Santa Rosa Island (see Figs. 18 and 19 for location). Calibrated radiocarbon ages of aeolianite units in (a) are taken from Table 1; U-series ages of marine terrace corals are from Muhs et al. (2015). Photo by D.R. Muhs. (b) Exposure (SRI-140) west of Carrington Point on Santa Rosa Island (see Figs. 18, 19 for location) showing internal stratigraphy within a Holocene linear dune and calibrated radiocarbon ages of land snails in paleosols (taken from Table 1). Note also eroded surface of Green Mountain soil developed on middle Pleistocene aeolianite which can be traced seaward to SRI126 section (Fig. 19). (For interpretation of the references to color in this figure legend, the reader is referred to the web version of this article.)

Photograph by D.R. Muhs.
Point (Fig. 24c), which has more calcite than either local Bechers Bay beach sand or Sandy Point beach sand. Comparing quartz, plagioclase, and calcite shows that Holocene, late Pleistocene, and middle Pleistocene aeolian sands or aeolianite all have higher carbonate content than modern beach sands on Santa Rosa Island (Fig. 24).

\section{Reconnaissance studies of aeolianite on Santa Cruz Island}

Santa Cruz Island (Fig. 25) is the largest of the Channel Islands and has a much more complex geology than any of the others. However, the geology of the easternmost part of the island, where our studies were conducted, is simpler than farther west and is dominated by three rock units. The oldest of these units is the Santa Cruz Island Volcanics of Miocene age, with ${ }^{40} \mathrm{Ar} /{ }^{39} \mathrm{Ar}$ ages of $17-16$ Ma (Luyendyk et al. 1998). The volcanic rocks of the eastern part of Santa Cruz Island are overlain in places by the Miocene Monterey Formation (Fig. 26a). The Monterey Formation is siliceous marine shale that also contains bentonite, carbonate nodules, and marine fossils. Along the northeastern coast of Santa Cruz Island, the Monterey Formation is overlain by what Weaver et al. (1969) called the Potato Harbor Formation (Fig. 26a). The lowermost part of the Potato Harbor Formation is fossiliferous marine terrace sand and gravel. Weaver and Meyer (1969) considered the marine terrace facies of the Potato Harbor Formation to be of Pliocene age, based on the presence of an extinct faunal element, Pecten healeyi, but Scott and Pinter (2003) correlated the terrace with the $\sim 400 \mathrm{ka}$ MIS 11 high stand of sea. We have no new age data for the fossils in this marine terrace deposit, but we suspect it is likely somewhere between the age estimates of Weaver and Meyer (1969) and Scott and Pinter (2003). Using the highest elevation of the $\sim 120,000$-yr-old marine terrace reported by Pinter et al. (2003), Muhs et al. (2014) calculated a maximum possible late Quaternary uplift rate of $\sim 0.09 \mathrm{~m} / 1000 \mathrm{yr}$ on Santa Cruz Island. Using this uplift rate, the marine bench at $\sim 85 \mathrm{~m}$ in northeastern Santa Cruz Island could be at least $\sim 900,000$ to $\sim 1,000,000 \mathrm{yr}$ old. Weaver et al. (1969) considered aeolianite of highly variable thickness that overlies the marine terrace deposits to be part of the Potato Harbor Formation (Fig. 26a and b).

Reconnaissance studies were made of the aeolianite facies of the Potato Harbor Formation. At Cavern Point, the marine bench cut on the Santa Cruz Island Volcanics is overlain by fossiliferous marine sand and gravel. A paleosol with a Bw horizon has developed in the upper part of these marine terrace deposits and this buried soil is in turn overlain by aeolianite (Fig. 26c). Aeolianite here ranges in thickness from $1.5 \mathrm{~m}$ to $11 \mathrm{~m}$, but elsewhere, near Potato Harbor (Fig. 25b), it is as much as $\sim 33 \mathrm{~m}$ thick. The thicker aeolianite near Potato Harbor appears to have been deposited episodically, as paleosols with calcrete Bk horizons are intercalated with aeolian sand. Because of the difficulty of access on these treacherous cliffs, precise measurements of stratigraphic units near Potato Harbor were not possible. However, in the lower part of the aeolianite near Potato Harbor, beds with dips of $20^{\circ}$ to $26^{\circ}$ to the south were measured. At Cavern Point, the single aeolianite unit exposed is well cemented and hosts a large number of calcite rhizoliths in its upper part. Despite the abundance of these secondary features, high-angle $\left(\sim 27^{\circ}\right)$ foreset beds are still apparent and dip to the east (Fig. 26c and d). Thus, at least for the Cavern Point area, we infer paleowinds from the west at the time of dune formation. 
(a)

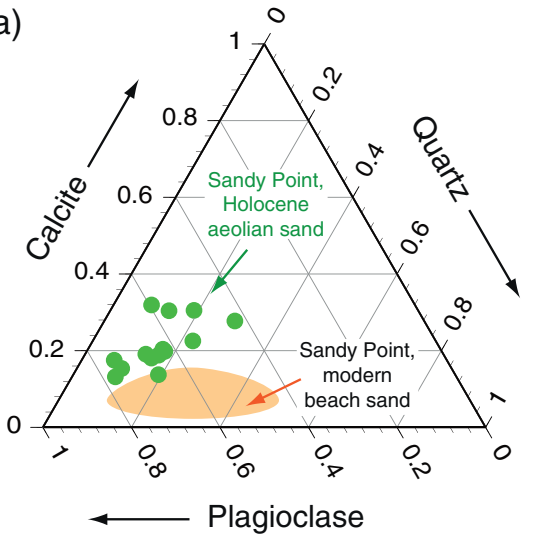

(c)

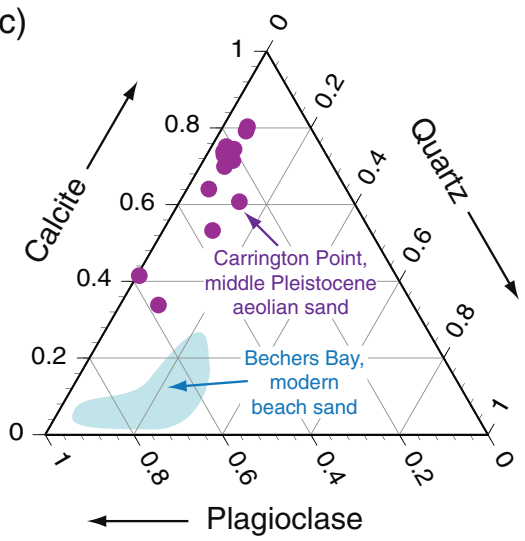

(b)

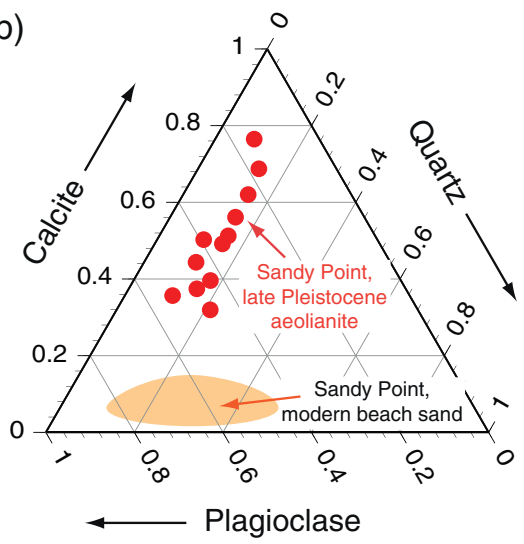

Fig. 24. Ternary diagrams showing composition of Santa Rosa Island aeolian sand and aeolianite compared to modern beach sand ( $<500 \mu \mathrm{m}$ fraction; see Fig. 18 for locations): (a) aeolian sand of Holocene age at SRI-27 (Figs. 18, 19); (b) aeolianite of late Pleistocene age at SRI27 (Figs. 18, 19); (c) middle Pleistocene aeolianite at SRI126) west of Carrington Point (Figs. 18, 19, 20). Diagrams were constructed using X-ray diffractogram peak heights for quartz $\left(20.9^{\circ} 2 \theta\right.$, Cu radiation), plagioclase $\left(27.8-28.0^{\circ} 2 \theta\right)$, and calcite $\left(29.4^{\circ} 2 \theta\right)$; thus the diagrams portray relative, not absolute abundances of these minerals.

\section{Discussion}

\subsection{Origin of carbonate-rich aeolian sand and aeolianite on the northern Channel Islands}

The occurrence of carbonate-rich beach and aeolian sand on the northern Channel Islands is unusual for the Pacific Coast of North America. Aeolian sands along most of this coast, from Baja California, Mexico to southern Canada, are composed largely of quartz, plagioclase, K-feldspar, and silicate-dominated rock fragments. Results reported here show that aeolian sand on the northern Channel Islands is dominated by carbonate minerals (calcite and/or aragonite), with subordinate amounts of quartz, plagioclase and K-feldspar. Total carbonate mineral contents in Pleistocene aeolianite on San Miguel Island are $60-80 \%$. On Santa Rosa Island, late Pleistocene aeolianite (from the Sandy Point area) has somewhat lower carbonate contents, but still ranges from $40 \%$ to $70 \%$. Muhs et al. (2009) also reported high (30\% to $40 \%$ ) carbonate mineral contents for aeolian sand and aeolianite of Pleistocene age on San Nicolas Island and San Clemente Island. In contrast, mainland California aeolian sands contain at most a few percent carbonate and some of these sands contain no measurable carbonate at all.

Finding an explanation for the high carbonate content of Channel Islands aeolian sands requires consideration of two different processes, one oceanographic and biologic, and the other geologic and geomorphic. The first of these is high biological productivity offshore. The cold California Current bathes the Pacific Coast of North America and is similar to cold eastern boundary currents found along the west coasts of other continents (Fig. 1). Associated with the California Current along the coast are numerous upwelling cells, also found associated with other eastern boundary currents (Carr 2001; Carr and Kearns 2003; Blanchette et al. 2009). Upwelling brings nutrient-rich deep waters to shallower depths and results in very high productivity of marine organisms composed of calcium carbonate, including mollusks, echinoderms, crustaceans, corals, coralline algae and others. Thus, waters adjacent to continents bathed by eastern boundary currents and associated upwelling are part of the "cool-water carbonate factory" described by James and Jones (2016). Emery (1960) reported that shelves of the Channel Islands averaged $\sim 27 \%$ calcium carbonate and bank tops averaged 56\% calcium carbonate. Norris (1951) reported that most insular shelf sands to the northwest of San Nicolas Island have carbonate contents of $40-80 \%$ and range up to $100 \%$. It is notable that aeolianites on the Canary Islands, also bathed by a cold eastern boundary current with upwelling, are among aeolian sands with the highest carbonate contents (Fig. 11d). This may explain why, on a global scale, carbonate aeolianites are distributed in two zones: in the tropical "warm-water carbonate factory" and along continents and islands that are affected by cold eastern boundary currents and upwelling, parts of the "cool-water carbonate factory" (Fig. 1).

The second process that explains the carbonate-rich aeolian sands of the Channel Islands is geologic and geomorphic in nature. If high biological productivity alone were responsible for carbonate-rich aeolian sands, then we could expect to see carbonate-rich dunes all along the mainland California and Oregon coasts, adjacent to the California Current and its upwelling zones. However, due to the tectonically active nature of the Pacific Coast of North America, the mainland is characterized in most places by rugged coastal mountains, composed dominantly of silicate-mineral-rich rocks. This, combined with steep, highly dissected terrain, results in efficient transport of silicate-rich sands from the North American mainland to the continental shelf. For example, Santa Monica Basin, which receives sediment from mainland fluvial sources, has estimated Holocene sedimentation rates of $40-90 \mathrm{mg} / \mathrm{cm}^{2} / \mathrm{yr}$ and Santa Barbara Basin, also fed by mainland fluvial sources, has Holocene rates of $80-130 \mathrm{mg} / \mathrm{cm}^{2} / \mathrm{yr}$ (Gorsline and Teng 1989). Mainland California coastal dunes, therefore, derive most of their sediment from coastal mountain range rocks that are rich in 
(a)

SANTA BARBARA CHANNEL

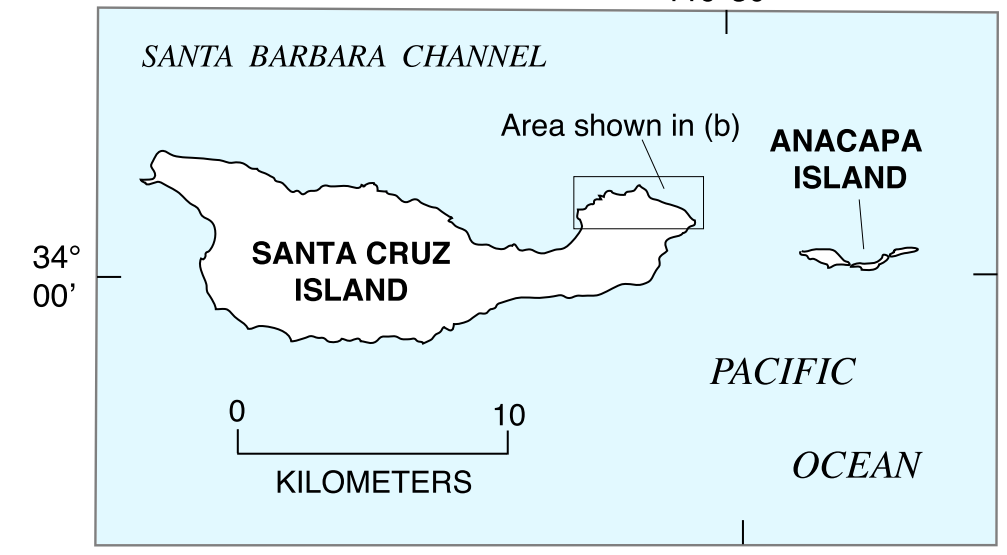

(b) $119^{\circ} 35^{\prime} 00^{\prime \prime}$

$119^{\circ} 32^{\prime} 30^{\prime \prime}$

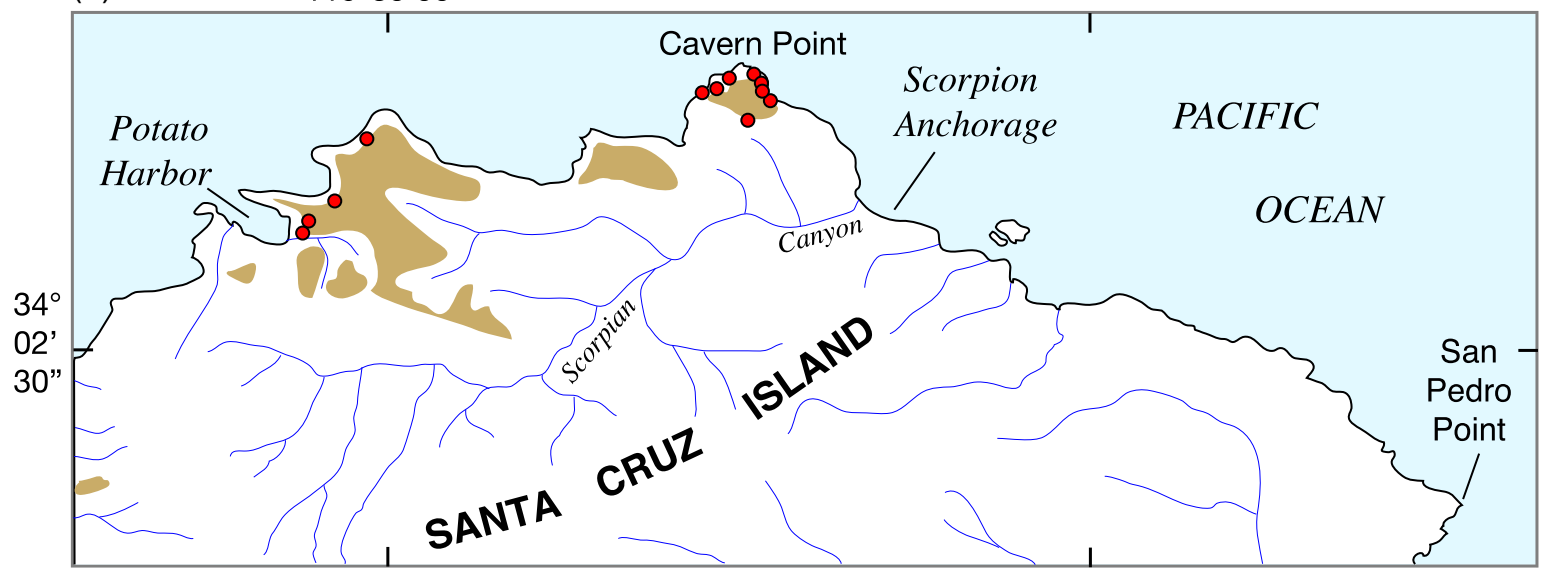

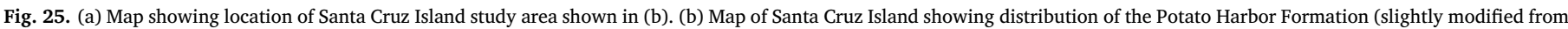
Weaver et al. 1969), much of which is composed of aeolianite. Also shown are locations of aeolianite exposures studied within this formation.

quartz and feldspar. Thus, although offshore biogenic carbonate sediment production is high along parts of the mainland California coast, skeletal sands are diluted by significant inputs of silicate minerals derived from coastal mountain ranges. Emery (1960) reports that mainland sand beaches in southern California average only $\sim 6 \%$ calcium carbonate and mainland shelves average only $\sim 9 \%$ calcium carbonate.

In contrast to mainland settings, most of the Channel Islands lack mountainous terrain. As a result, silicate minerals do not dilute offshore biogenic carbonate sands around these islands to the degree that they do on the mainland. In contrast to the mainland, basins adjacent to islands, such as Santa Catalina Basin and San Nicolas Basin, both well offshore and protected from mainland fluvial sources, have Holocene sedimentation rates of only $10-25$ and $10-20 \mathrm{mg} / \mathrm{cm}^{2} / \mathrm{yr}$, respectively (Gorsline and Teng 1989). Whereas on the mainland, high biological productivity and generation of carbonate mineral grains are exceeded by delivery of silicate mineral grains, on the Channel Islands, biogenic carbonate grain production rates exceed fluvial silicate grain delivery rates. This explains why the Channel Islands have the northernmost carbonate-rich aeolian sand yet reported on the coasts of the Americas. Nowhere north of Point Conception on the Pacific Coast (Fig. 2b) has the appropriate combination of high biological productivity and a geographic and geologic setting where high biogenic sand production is not diluted by mainland silicate sand input. In this regard, Channel Islands aeolianites have some similarity to Australian aeolianites, even though the latter occur on a continental coastline. In South Australia and Western Australia, fluvial input to the continental shelf is minimal because of the arid climate and subdued topography, whereas biological production offshore is high (Collins 1988; James and Bone 2011; Brooke et al. 2014; Murray-Wallace 2014; Short 2014; Bourman et al.
2016). Thus, shelf sediments off Australia are rich in carbonate sands, providing the sources for the extensive aeolianites along the coast.

Within the suite of aeolian sands studied on the Channel Islands, however, there are differences in carbonate content from island to island. Overall, carbonate content is highest on San Miguel Island, lower on Santa Rosa Island, and lowest on San Nicolas Island and San Clemente Island (see Muhs et al. 2009 for data on the latter two islands). This general trend may be a function of the position of each island with respect to the California Current and its associated upwelling (Fig. 2), as well as the size of the shelf areas to the west and northwest of a given island. South of Point Conception, where the mainland California coast changes from a north-south to an east-west orientation, the California Current is farther offshore and farther from the islands. Thus, while San Miguel Island, close to Point Conception, receives much of the full impact of the California Current and its associated upwelling, the other islands are farther away and somewhat protected from this current. San Clemente Island is the farthest removed from the California Current of all of these islands and the carbonate content of its aeolian sand is lower than all of the other islands (Muhs et al. 2009).

Even on a given island, carbonate content is variable among aeolian sands of different ages. The best example of this is on Santa Rosa Island, where aeolian sand of late Pleistocene age near Sandy Point has carbonate contents of $42-68 \%$ whereas that of possible middle Pleistocene age near Carrington Point has carbonate contents of 32-49\%. Furthermore, the late Pleistocene aeolian sands at Sandy Point contain both aragonite and calcite, whereas those at Carrington Point contain only calcite. James and Jones (2016) point out that given the unstable nature of both aragonite and high-Mg calcite in the subaerial 

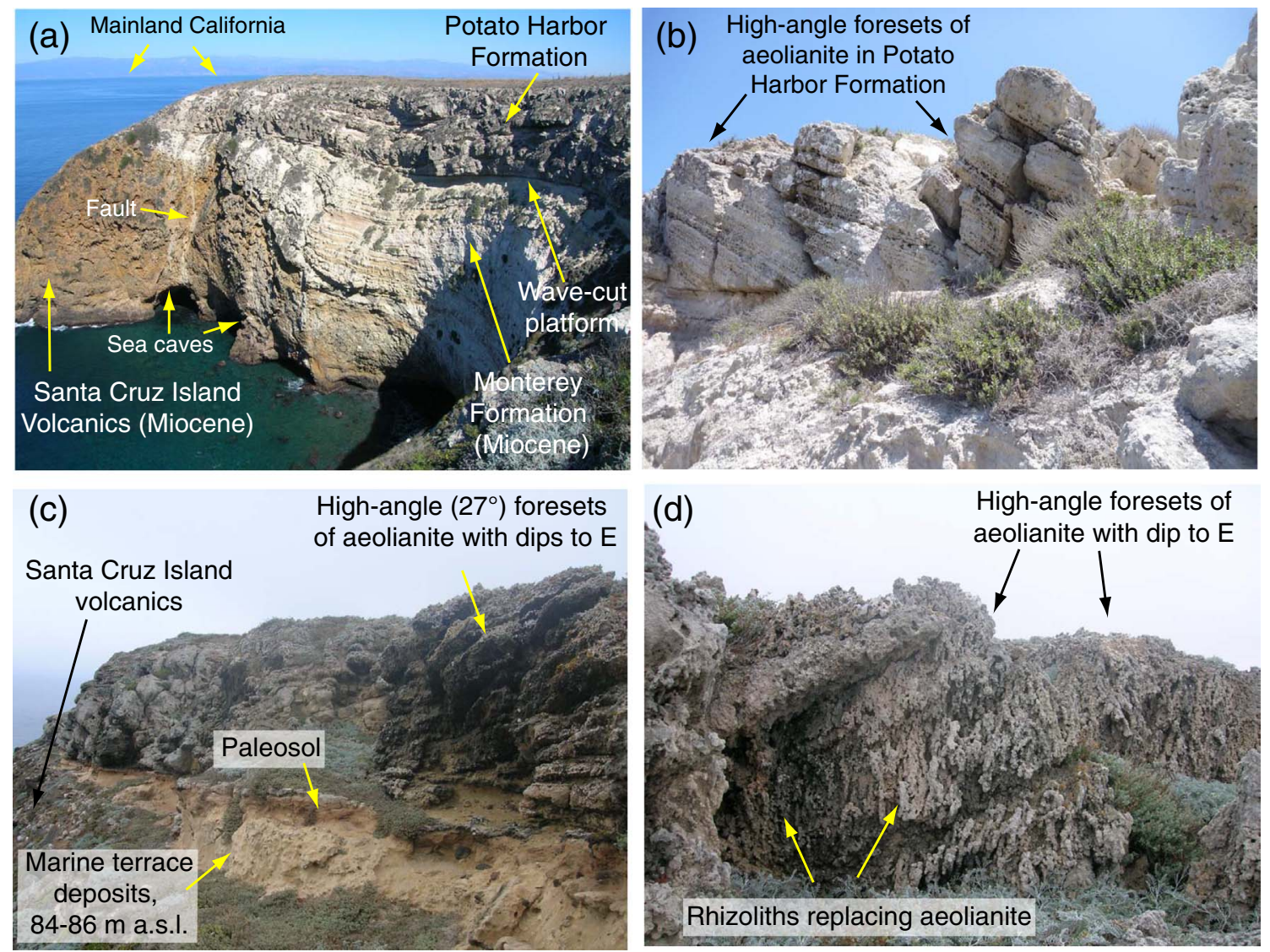

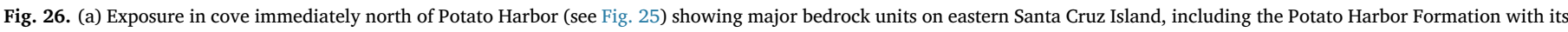

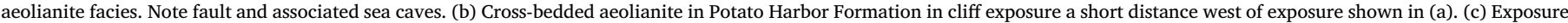

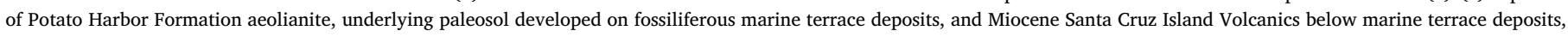

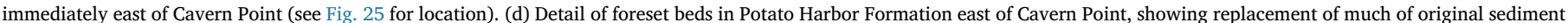
body with calcite rhizoliths.

Photographs by D.R. Muhs.

environment, it is common for carbonate sediments or rocks to experience gradual, diagenetic conversion of aragonite and high-Mg calcite to low-Mg calcite. On Santa Rosa Island, this has apparently taken place over the past few hundred thousand years to the point of complete alteration of any original aragonite grains.

Another example of variability in carbonate content within different-aged aeolian sands on a single island is that observed on San Miguel Island for late Pleistocene and Holocene aeolian sands. At the Hobbit House section, the highest carbonate mineral content is found within the late Pleistocene Yardang aeolianite (Figs. 9, 10). Modern beach sands collected along both Simonton Cove and Cuyler Harbor (Fig. 3) have similar carbonate contents to each other, but both groups of beach sands have significantly lower carbonate contents than aeolian sands in the Yardang aeolianite. Interestingly, however, Holocene aeolian sands that lie above the Midden soil have carbonate contents that are intermediate between modern beach sands and the Yardang aeolianite (Fig. 10). These observations suggest the possibility that Holocene aeolian sands on San Miguel Island are derived partially from reworking of late Pleistocene aeolian sand, but were also fed by inputs from modern beaches.

An interesting question that arises from observations of variable carbonate content is why late Pleistocene aeolian sand on San Miguel Island has a higher carbonate content than that of modern beach sands. One possibility is that biological productivity was greater in the past than at present. This could have occurred during the last interglacial complex (MIS 5), when most of the insular shelf off San Miguel Island was submerged. However, another possibility is that the late Pleistocene aeolianites exposed along Simonton Cove at present are the distal portions of a dune field that extended as much as $15 \mathrm{~km}$ to the northwest of the present coast of San Miguel Island (see discussion below). We hypothesize that shelf sediments in this more northwesterly location, closer to the California Current and undiluted by silicate inputs from the island, have higher carbonate contents than what is found on modern San Miguel Island beaches. As an analog, Muhs et al. (2009) reported that modern beach sands on San Nicolas Island have lower mean calcium carbonate contents than modern insular shelf sands, to the northwest of the island, reported by Norris (1951). Emery (1960) showed that carbonate contents on the insular shelves of Santa Catalina Island, Santa Barbara Island, and Anacapa Island are relatively low close to shore and much higher in a seaward direction.

\subsection{Chronology of carbonate-rich aeolian sand deposition on San Miguel Island}

Our most detailed reconstruction of aeolian sand depositional history comes from San Miguel Island. Three aeolian sand units, not including the veneer of historical and/or Holocene aeolian sand, are recognized. The oldest unit is found only on higher-elevation, pre-lastinterglacial complex (MIS 5) marine terraces and is characterized by the Green Mountain soil with its distinctive A/E/Bt/Bk/C profiles, with $\mathrm{Fe}$ pisoliths in the $\mathrm{E}$ and upper Bt horizons. The age of this aeolian sand is unknown, but an estimate can be made using a combination of late Quaternary uplift rate, marine terrace elevation, and stratigraphic relations. Muhs et al. (2014) reported a late Quaternary uplift rate of $\sim 0.15 \mathrm{~m} / 1000 \mathrm{yr}$ for the $\sim 24$-m-high last-interglacial $(\sim 120,000 \mathrm{yr})$ marine terrace on San Miguel Island, assuming a paleo-sea level of 
$+6 \mathrm{~m}$ relative to present. The outer edge of the lowest marine terrace on San Miguel Island that has overlying aeolianite sand hosting the Green Mountain soil has an elevation on the order of $\sim 100 \mathrm{~m}$. Assuming a constant uplift rate over the middle-to-late Pleistocene, this yields a maximum-limiting age of $\sim 700,000-600,000 \mathrm{yr}$, similar to the oldest aeolianite on Santa Rosa Island. Based on the extent of the Qeo unit as shown in Figure 3, aeolian sand deposition during this period was extensive, covering much of the interior of the island.

The next youngest aeolian unit (Qes/Qto) is also found on some of the highest marine terraces, but does not host the Green Mountain soil. This unit is found in areas of the island that are seaward of the Qeo/Qto unit. Soils in this aeolian unit rarely have preserved A horizons, but strong brown to yellowish-brown Bt horizons and Bk horizons are almost always present. The less extensive degree of soil development compared to the Green Mountain Soil indicates that this is a considerably younger aeolian sand. Its age is uncertain as we have not found datable materials within it. Based on the similar degree of soil development, however, it is likely that the aeolian unit Qes/Qto is of approximately same age as the oldest subunit within the youngest mapped unit, Qey/Qty. The reddish-brown Bt horizons and laminar calcrete Bk horizons of the soils hosted by the Qes unit are very similar to Simonton soils in the lower part of unit Qey. Unit Qes could therefore be simply an inland facies of the older aeolian sand found within unit Qey.

The youngest (apart from historically active sand) aeolian sand unit recognized, Qey/Qty, is found around the coast of much of the island, except for the southern coast. The lower, thin aeolian packages within this unit host the Simonton I and Simonton II soils, which have morphologies (Bt and Bk horizons) similar to that found in the upper parts of unit Qes/Qto. As discussed above, this observation indicates the possibility that unit Qes/Qto and the lower parts of Qey/Qty could be of similar age. Because we have not found exposures that allow us to trace the buried Simonton soil I and Simonton soil II of Qey/Qty laterally to the surface soils of Qes/Qto, this remains as a hypothesis to be tested in future studies.

The best age estimates for aeolian sand deposition on San Miguel Island come from the Qey/Qty unit. From the four stratigraphic sections we studied, we recognize four periods of aeolian sand deposition. Because all aeolian units rest on either the $\sim 120,000 \mathrm{yr}$ or $80,000 \mathrm{yr}$ marine terraces, all windblown sediments of this unit post-date the last interglacial complex, MIS 5. The lowest two aeolian units, capped by the Simonton I and Simonton II paleosols, are what Johnson (1972, 1977, 1980) referred to as the "Simonton Sedimentary Complex." Although these deposits are only a few meters thick at most, they can be recognized along much of the length of Simonton Cove. At the Hobbit House section, the lowest aeolian unit rests on what we interpret to be the 120,000-yr-old (MIS 5.5) and 80,000-yr-old (MIS 5.1) marine terraces (Fig. 7). For simplicity we refer to this aeolian sand as "Older Aeolianite I" and Simonton soil I is developed in the upper part of it. Radiocarbon ages from Simonton soil I are $>50,000 \mathrm{yr}$. This would indicate deposition of Older Aeolianite I sometime between $80,000 \mathrm{yr}$ and 50,000 yr. Radiocarbon ages from what we interpret to be $\mathrm{Si}$ monton soil I at the "Beachrock" section are also likely > 50,000 years old. If our interpretation of this paleosol as the Simonton I soil is correct, this indicates deposition of the lowermost aeolian sand between 80,000 and 50,000 yr, consistent with the Hobbit House section. An $\mathrm{IR}_{50}$ age of 75,000 $\pm 11,000 \mathrm{yr}$ (SMI-2, Table 2 ) is consistent with this estimate. Older Aeolianite I was therefore likely deposited during MIS 4 or possibly early MIS 3.

The deposit underlain by Simonton soil I and overlain by Simonton soil II we refer to as "Older Aeolianite II." At the Hobbit House section, calibrated radiocarbon ages on charcoal from within Simonton soil II range from $\sim 36,200 \mathrm{yr}$ (lowest sample) to $\sim 26,100 \mathrm{yr}$ (uppermost sample). This indicates Older Aeolianite II was deposited prior to $\sim 36,000 \mathrm{yr}$, but perhaps after $\sim 50,000 \mathrm{yr}$, sometime within MIS 3 . $\mathrm{IR}_{50}$ ages (Table 2) from Older Aeolianite II of 48,000 $\pm 7000 \mathrm{yr}$ (lower part, SMI-3) and 38,000 $\pm 6000 \mathrm{yr}$ (upper part, SMI-4) are consistent with this interpretation. The radiocarbon ages also indicate that Simonton soil II developed over a fairly long period of $\sim 10,000 \mathrm{yr}$, from at least $\sim 36,200 \mathrm{yr}$ to at least $\sim 26,100 \mathrm{yr}$. Calibrated radiocarbon ages on both charcoal and a land snail from the Yardang canyon section are broadly consistent with this interpretation and indicate that Simonton soil II was still developing as late as $\sim 24,500 \mathrm{yr}$.

The period of thickest and most rapid Pleistocene aeolian sand accumulation on San Miguel Island is represented by the Yardang aeolianite. At both the Hobbit House section and just east of the Yardang canyon section, this unit consists of as much as $16 \mathrm{~m}$ of cross-bedded, carbonate-rich sand, weakly cemented into aeolianite. Calibrated radiocarbon ages from the Hobbit House section indicate that this unit was emplaced between $\sim 26,100 \mathrm{yr}$ (uppermost age from the Simonton II paleosol) and $\sim 14,900 \mathrm{yr}$ (rhizoliths from the lower part of the overlying Midden paleosol). $\mathrm{IR}_{50}$ ages from within this unit indicate aeolian sand accumulation from $\sim 26,000 \mathrm{yr}$ to $\sim 21,000 \mathrm{yr}$ and possibly as late as $\sim 18,000 \mathrm{yr}$, which agree well with the bracketing radiocarbon ages. At Yardang canyon, bracketing calibrated radiocarbon ages from the same units are $\sim 24,500 \mathrm{yr}$ and $\sim 17,900 \mathrm{yr}$, respectively. Thus, both the radiocarbon and luminescence ages indicate deposition of the Yardang aeolianite during the last glacial maximum, or MIS 2.

It is interesting to note that Johnson (1977) reported bracketing radiocarbon ages that, when calibrated, are close to ours for the Yardang aeolianite at the Yardang canyon section. Johnson (1977) also pointed out that the small difference in age between the upper and lower ages indicated that the Yardang aeolianite was deposited rather rapidly during MIS 2. Our bracketing radiocarbon ages at the Hobbit House section support this interpretation. The similarity of multiple luminescence ages within the Yardang aeolianite at the Hobbit House section, over a depth of $\sim 12.5 \mathrm{~m}$, underscores an interpretation of rapid aeolian sedimentation at the last glacial maximum.

\subsection{Chronology of aeolianite deposition on Santa Rosa Island and Santa Cruz Island}

Although we have fewer geochronological data for aeolianite and aeolian sand on Santa Rosa Island, stratigraphic relations and other data allow us to make some inferences about the time of aeolian sand deposition. The aeolianite section exposed at Sandy Point (Fig. 23a) indicates that aeolianite deposition took place after $\sim 80,000 \mathrm{yr}$ (MIS 5.1 , based on U-series ages of corals from the underlying marine terrace deposits reported by Muhs et al. (2015). However, calibrated rhizolith ages of $\sim 30,000$ to $\sim 28,000 \mathrm{yr}$ indicate that by the latter part of MIS 3, aeolian deposition had ceased and sand was being stabilized by vegetation. If so, then the major period of aeolian sand deposition must have been during MIS 4, a glacial period, or the early part of the interstadial MIS 3, similar to what we observe in the older aeolianites on San Miguel Island.

At Coati Point (Fig. 21), falling dunes, some of them weakly cemented into aeolianite, were deposited after either MIS 5.5 or 5.3, based on U-series ages of corals from the marine terrace deposits underlying the 14-m-thick aeolian package (Muhs et al. 2015). The land snails in the lower part of the aeolian package yielded ages of $\sim 46,000 \mathrm{yr}$, but we interpret these as likely beyond the range of radiocarbon dating. Thus, correlation of the overlying aeolianite package to MIS 4, 3, or 2 could be possible. In any interpretation, however, the thick aeolianite sequence at Coati Point indicates aeolian deposition after the last interglacial period (either MIS 5.5 or 5.3). Similar observations are made for the aeolian sand exposures along Southeast Anchorage on Santa Rosa Island (Fig. 22). These aeolian packages overlie the same marine terrace as at Coati Point, and thus are younger than MIS 5.5 or 5.3. Well-developed soils in their upper parts indicate that they are not sands of Holocene age. Furthermore, the presence of probable mammoth tracks within some of the sands implies 
that the deposits are no younger than the youngest mammoths found on Santa Rosa Island, which are between $\sim 13,000$ and $\sim 12,000$ yr. Thus, these aeolian sands could have been deposited during MIS 4, 3, or 2, similar to the falling dunes at Coati Point.

Finally, observations on Santa Rosa Island and Santa Cruz Island indicate that aeolianites of probable middle Pleistocene or early Pleistocene age were likely deposited during glacial periods. At Carrington Point on Santa Rosa Island, thick, cross-bedded aeolianite, with foresets dipping landward, are perched on an uplifted marine terrace at $\sim 95 \mathrm{~m}$ above sea level (Fig. 20). No sand source exists for such a deposit, as the foreset beds are situated on the high sea cliff immediately landward of the shore. Thus, prior to uplift of the aeolianite and the underlying marine terrace deposit, a sand source must have existed seaward of the present location of the cliff exposure, implying a lower, glacial-age sea level. The age of such a glacial period is unknown, but based on the uplift-rate-inferred age of the marine terrace discussed earlier, it could be as old as $\sim 650,000-600,000$ yr. Because the aeolianite here has a Green Mountain Soil developed in its upper part (although largely eroded), this could also be an approximate timing of the formation of older aeolianite that hosts a similar soil on San Miguel Island (Fig. 3).

On Santa Cruz Island, a relation similar to that of the older aeolianite on Santa Rosa Island exists with the aeolianite facies of the Potato Harbor Formation. Here again, aeolianites with foreset beds dipping landward are perched on an uplifted marine terrace well above the modern shore, but with no sand source below (Fig. 26). The age of the terrace is unknown, but based on an assumption of a constant rate of uplift, it could be as much as a million years old. Common to late, middle, and early Pleistocene aeolianites on the northern Channel Islands is the observation that aeolian sands overlie marine terrace deposits, as opposed to grading into them laterally, as a facies change. Furthermore, a paleosol is developed in the marine deposits (Figs. 20c, $21,26 \mathrm{c}$ ), indicating some amount of time had elapsed after marine terrace emergence but before aeolianite deposition. Presumably, this period of pedogenesis occurred during slow regression of the sea during the initial phase of a glacial period. Thus, based on the geomorphic and stratigraphic observations and geochronologic data from San Miguel Island, Santa Rosa Island, and Santa Cruz Island, we infer that aeolianite deposition on the northern Channel Islands seems to be related primarily to glacial or interstadial periods, not interglacial periods, and this pattern was repeated throughout the Pleistocene.

7.4. Aeolianite deposition and its relation to sea level: comparison of the Channel Islands with other regions worldwide

Based on the late Pleistocene chronology of aeolian deposition outlined above, much of the sand deposition on San Miguel Island and Santa Rosa Island took place after the last interglacial period, or MIS 5.5. Sea levels during MIS 4, 3, and 2 (from $\sim 75,000 \mathrm{yr}$ to $\sim 15,000 \mathrm{yr}$ ) were substantially lower than present and certainly much lower than during the high sea-stands all through MIS 5 (from $\sim 120,000 \mathrm{yr}$ to $\sim 80,000 \mathrm{yr}$ ). Using the sea level curve of Muhs et al. (2012b), shown in Figure 27, reconstruction from bathymetric maps demonstrates that during the early glacial of MIS 4 ( $\sim 65,000 \mathrm{yr}$ ), the interstadial of MIS 3 $(\sim 40,000-35,000 \mathrm{yr})$, and the last glacial maximum of MIS 2 $(\sim 25,000-20,000 \mathrm{yr})$, significant source areas of shelf sands would have been exposed at all these times (Fig. 28). The geochronology presented earlier for San Miguel Island shows that periods of carbonate sand accumulation likely took place during MIS 4 and MIS 3, and particularly during MIS 2 (Fig. 27). Furthermore, the geomorphic and stratigraphic evidence from Santa Rosa Island and Santa Cruz Island indicates that it is likely that aeolian sand deposition took place during glacial periods in the middle Pleistocene and early Pleistocene as well.

The concept of aeolianite accumulation during glacial periods is contrary to a broad generalization by some investigators that such deposits are primarily interglacial sea level indicators (Hearty and O'Leary
2008; James and Bone 2015; James and Jones 2016). Nevertheless, examination of aeolianites from other coastlines around the world indicates that the findings from the California Channel Islands are not unique. Aeolianites on Porto Santo, Madeira, have been dated directly to the last glacial period, $\sim 25,000-15,000 \mathrm{yr}$ (Lietz and Schwarzbach 1971). Butzer (1975) noted that on Mallorca, aeolianites exist where there is no sand supply at present, and this is supported by our own observations of landward-dipping foresets perched directly above the modern shore on that island (Fig. 29a). On Sardinia, landward-dipping aeolianite foresets, like Mallorca, can be found adjacent to the modern shore, implying a source now offshore (Fig. 29b). In support of these observations, Andreucci et al. (2010a, 2010b) report luminescence ages of aeolianites on Sardinia that date to glacial or interstadial periods MIS $8,6,4$, and 3 , all times when sea level was much lower than present. In Israel, early studies showed that aeolianites (locally called "kurkar") occur offshore, in waters as deep as $\sim 100 \mathrm{~m}$, implying formation during a low stand of sea, and hypothesized to be of last-glacial age (Almagor 1979). Later studies using luminescence dating, done onshore along the Mediterranean coast of Israel, show that many aeolianites formed during either MIS 4 and/or MIS 3 (Frechen et al. 2002; Porat et al. 2004; Sivan and Porat 2004). On the island of Puerto Rico, aeolianites are found along much of the modern, northern shore (Kaye 1959). We have observed aeolianites on the north shore of this island with high-angle foresets dipping landward (south), indicating that the source of sand must have been to the north, on what is now the submerged insular shelf (Fig. 29c).

In those areas where aeolianite has been studied the most, Australia, South Africa, and Bermuda, investigations of the past 15 years have brought about revisions to the concepts of how these sediments accumulate with regard to sea level. For example, Brooke et al. (2014) show that in Australia, aeolianite deposition took place during glacial periods MIS 4 and MIS 2, as well as during the peak of the last interglacial period, MIS 5.5. In South Africa, Bateman et al. (2004) report luminescence ages indicating aeolianite deposition during MIS 4, 5, and 6 (i.e., two glacial periods as well as during an interglacial period). Finally, Rowe and Bristow (2015a, 2015b) have revised some of the concepts of Bermudan aeolianite deposition. They emphasize that aeolian sand accumulated as sea level was falling, i.e., in the transition

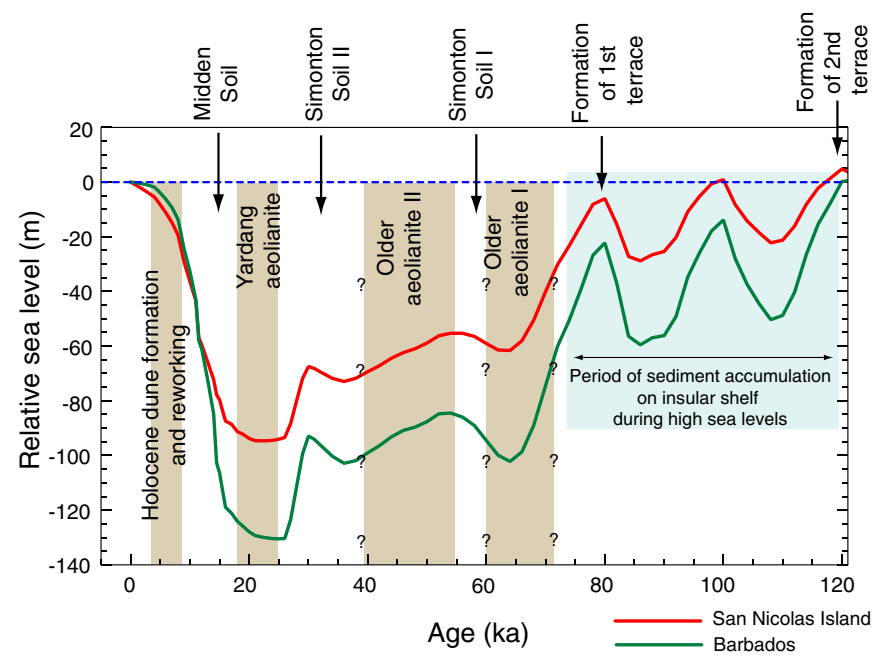

Fig. 27. Sea level history over the past $\sim 120,000 \mathrm{yr}$ according to the Barbados-derived coral reef record (green line; considered to be approximately eustatic) and that off southern California (red line), modified for glacial isostatic adjustment (GIA) processes by Muhs et al. (2012b). Also shown are times of hypothesized carbonate skeletal particle buildup during interglacial high-sea stands (blue shaded area), hypothesized times of aeolianite deposition on the Channel Islands based on geochronology given in this study, during relatively low stands of sea, and times of paleosol formation, during slightly higher stands of sea. (For interpretation of the references to color in this figure legend, the reader is referred to the web version of this article.) 


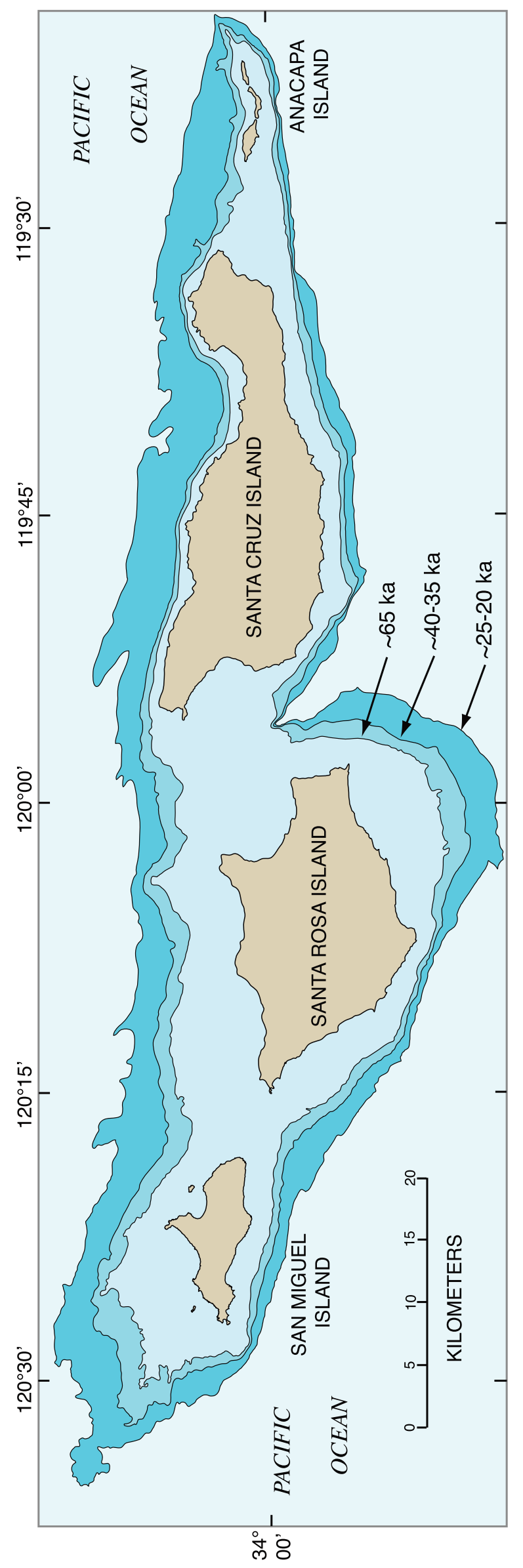

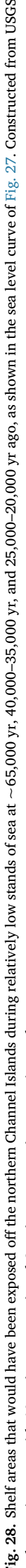

between an interglacial high-sea stand and a following glacial low-sea stand. This relationship is seen very clearly in coastal sections of Bermuda, where landward-dipping aeolianite foreset beds occur immediately next to the modern shore, requiring deposition from a source that must have come from an area presently offshore (Fig. 29d).

One potential problem with the concept of aeolianite accumulation during low stands of sea is the idea that shelf sands could become cemented when freshly exposed, before aeolian entrainment can take place. For example, in the Bahamas, Halley and Harris (1979) showed that cementation of carbonate ooids by terrestrial waters took place in 1000 years or less. Under such circumstances, any potential coastal dune field would be starved of source sediments. We consider that it is unlikely that such a scenario applies to last-glacial shelf sands on the Channel Islands, however, where rainfall is considerably lower than it is in the Bahamas. Holocene dunes on both San Miguel Island and Santa Rosa Island, though rich in carbonate, are not cemented, and even lastglacial sands on San Miguel Island are only weakly cemented into aeolianite. Older, mid-to-early Pleistocene sands on Santa Rosa Island and Santa Cruz Island are well cemented into aeolianite. These observations suggest that cementation to aeolianite may be a fairly gradual process on the Channel Islands.

\section{Conclusions}

Coastal carbonate-rich dunes of Quaternary age, many cemented into aeolianite, occur on several of the California Channel Islands. These are the northernmost coastal carbonate aeolianites of which we are aware on the Pacific Coast of the Americas. Carbonate contents of aeolianites on the Channel Islands are very high compared to mainland dunes of California. The high carbonate content of aeolianites on the Channel Islands is due to a combination of two major factors, one of them oceanographic and biologic and the other geologic and geomorphic. Biological productivity off the California coast is high, because California is bordered by the south-flowing, cold California Current, which is accompanied by significant upwelling and delivery of nutrient-rich waters to shallow depths. Second, the California Channel Islands have limited land areas, gentle topography, and small drainage areas. Therefore, insular shelves receive only a minimum amount of terrestrial sediment from the islands' drainage basins in contrast to the mainland California coast with its steep, topographically rugged coastal mountains. High biological productivity combined with minimal dilution by silicate minerals results in shelf, beach, and aeolian sediments that are high in skeletal carbonate sands on the Channel Islands compared to the California mainland.

Several generations of carbonate aeolianites are present on the California Channel Islands and have been mapped in the present study. The oldest aeolianite mapped on San Miguel Island and Santa Rosa Island hosts well-developed soils and, based on stratigraphic relations with marine terraces, is older than $\sim 120,000 \mathrm{yr}$ and could be as much as 700,000 yr to $600,000 \mathrm{yr}$ old. Other aeolianites overlie pre-last-interglacial (MIS 5) marine terraces, but have a degree of soil development similar to those of aeolianites that overlie $\sim 120,000 \mathrm{yr}$ terraces. The youngest aeolianite unit mapped on both San Miguel Island and Santa Rosa Island is a sequence of three aeolian sand subunits overlying the $\sim 120,000 \mathrm{yr}$ and $\sim 80,000 \mathrm{yr}$ marine terraces. Based on both radiocarbon and luminescence methods, the oldest two aeolianite units in this sequence may date to the early part of the last glacial period, MIS 4 , and/or the interstadial that occurred during the last glacial period, MIS 3. The youngest Pleistocene unit in this sequence hosts the thickest aeolianite (up to $\sim 16 \mathrm{~m}$ ) on San Miguel Island and has maximumlimiting calibrated radiocarbon ages of $\sim 26,000$ to $24,000 \mathrm{yr}$ and directly dated luminescence ages of $\sim 26,000 \mathrm{yr}$ to $\sim 18,000 \mathrm{yr}$. Minimum-limiting calibrated radiocarbon ages range from $\sim 15,000$ to $\sim 13,000 \mathrm{yr}$ at one locality and $\sim 18,000$ to $\sim 17,000 \mathrm{yr}$ at another locality. These ages put the age of this youngest Pleistocene aeolianite squarely within the last glacial period, MIS 2. 


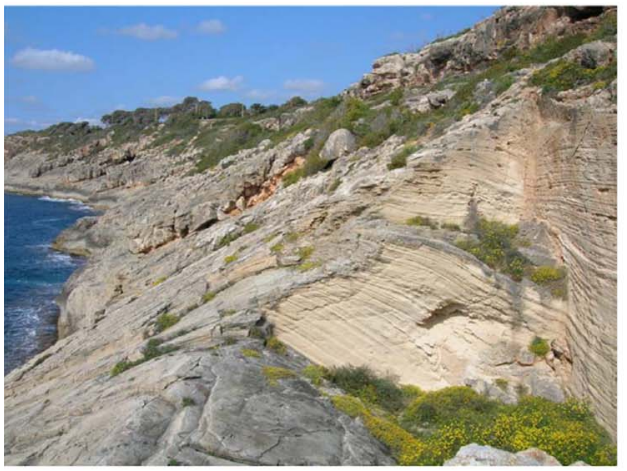

(a) S'estret de temps, southern Mallorca, Spain

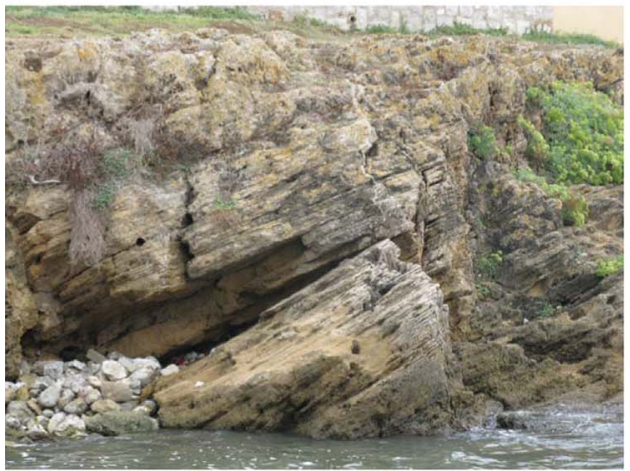

(b) Alghero, Sardina, Italy
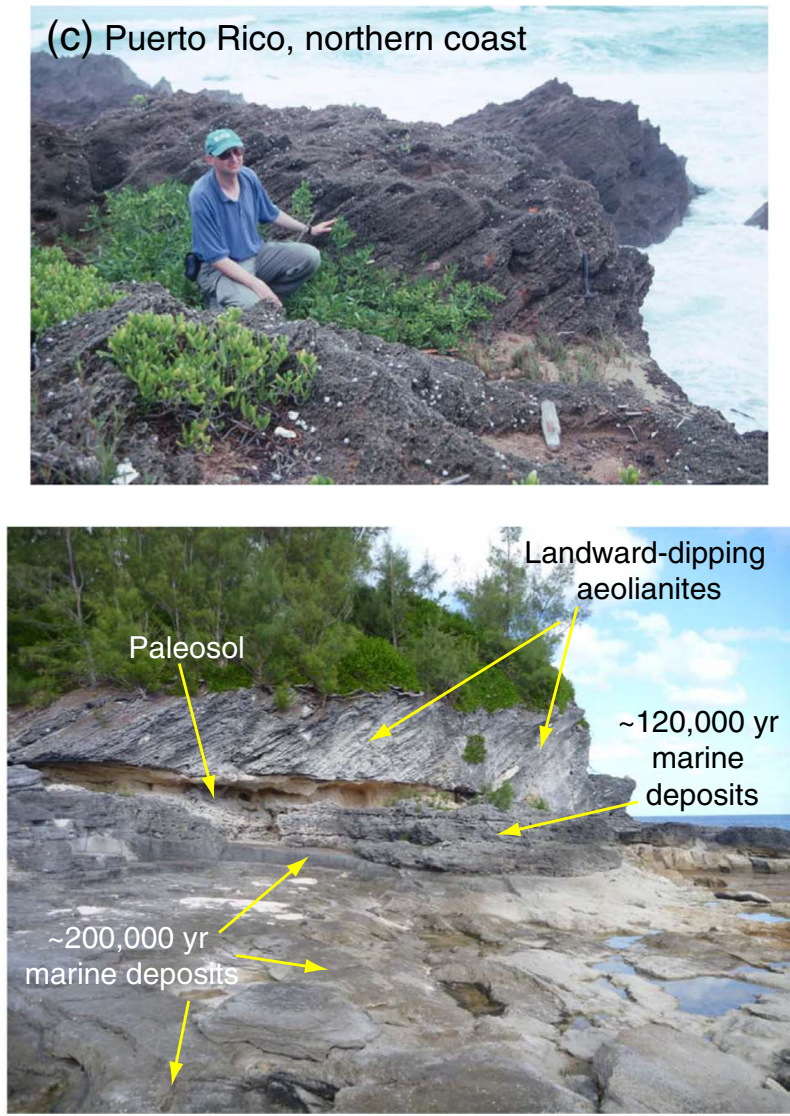

(d) Rocky Bay, Bermuda

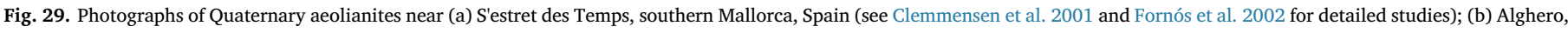

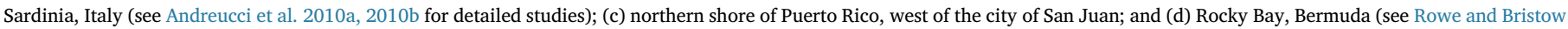

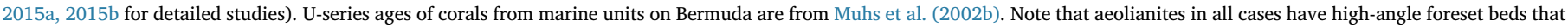
dip landward, but are very close to sea level and the present shoreline, requiring sources that are presently offshore.

All photographs by D.R. Muhs.

The geochronology of late Pleistocene aeolianite units found on San Miguel Island and Santa Rosa Island indicates deposition during MIS 4, 3 , and 2. Reconstruction of insular paleogeography using a sea-level history for the past $\sim 120,000 \mathrm{yr}$ indicates that large areas to the north and northwest of the Channel Islands would have been exposed at these times, providing a ready source of carbonate-rich skeletal sands that formed the parent material for the dunes.

Earlier, pre-last interglacial (i.e., pre-MIS 5) records of aeolianite deposition have been observed on Santa Rosa Island and Santa Cruz Island. Based on stratigraphic relations with the underlying marine terraces, these aeolianites may date to the middle Pleistocene and early Pleistocene, respectively. Nevertheless, based on bed geometry and geomorphic setting, specifically their proximity to the coast and a lack of source sediment, these aeolianites apparently also accumulated on the islands when sea level was low, presumably during earlier glacial periods of the Pleistocene, like their post-last-interglacial period counterparts. Thus, collectively on the Channel Islands, we find evidence of repeated low-sea-stand, glacial-age aeolianite formation, during the early, middle, and late Pleistocene.

The observation of aeolianite formation during glacial periods on the California Channel Islands contrasts with a concept, still championed by some investigators, that aeolianite deposition worldwide is dominantly an interglacial phenomenon. Nevertheless, glacial-age, sealevel-low-stand timing of aeolianite formation can be found in other localities as well, including Puerto Rico, Bermuda, Madeira, Mallorca, Sardinia, and Israel. In regions where aeolianite is extensive, such as Australia and South Africa, recent studies have shown that deposition of these sediments is complex, and glacial, interglacial, and interstadial periods can all be favorable times of formation. The findings reported here and by other investigators were foreshadowed more than a century and a half ago, when Darwin made simple observations of aeolianites on St. Helena in the South Atlantic Ocean and raised questions about their origins that required an appreciation of the complexity of sea level history and its effects on sediment origins.

Supplementary data to this article can be found online at https:// doi.org/10.1016/j.palaeo.2017.11.042.

\section{Acknowledgments}

This study was supported by the Climate and Land Use Change Research and Development Program of the U.S. Geological Survey (USGS) and is a contribution to the "Geologic Records of High Sea Levels" Project. Sincere thanks go to the U.S. National Park Service, Channel Islands National Park, and Kate Faulkner in particular, for field access and logistical support. Ian Williams, George Roberts, Lulis Cuevas, Mark Senning, Ed Smith, Sarah Chaney, Dave Begun, and Kelly Minas (all U.S. National Park Service) were knowledgeable and gracious hosts who assisted with field work during our many trips to San Miguel Island, Santa Rosa Island, and Santa Cruz Island. DeAnna Laurel (Colorado State University) and Sabine Faulhaber (NPS volunteer, then of UCSB) assisted with field work. Thanks go to Dave Loope (University of Nebraska-Lincoln) who examined our photographs of hypothesized mammoth tracks and confirmed their likely origin. A very special thank-you goes to our good friend and retired USGS colleague Jack 
McGeehin, who generated all of the radiocarbon ages presented here. Bob Halley (USGS, retired), editor Paul Hesse, John Wehmiller (University of Delaware), an anonymous reviewer, and Janet Slate (USGS) all made helpful comments on an earlier version of the manuscript, which we appreciate. Any use of trade, firm, or product names is for descriptive purposes only and does not imply endorsement by the U.S. government.

\section{References}

Agenbroad, L.D., 2005. North American proboscideans: mammoths: the state of knowledge. Quat. Int. 126-128, 73-92.

Almagor, G., 1979. Relict sandstones of Pleistocene age on the continental shelf of northern Sinai and Israel. Isr. J. Earth Sci. 28, 70-76.

Andreucci, S., Clemmensen, L.B., Pascucci, V., 2010a. Transgressive dune formation along a cliffed coast at $75 \mathrm{ka}$ in Sardinia, Western Mediterranean: a record of sea-level fall and increased windiness. Terra Nova 22, 424-433.

Andreucci, S., Clemmensen, L.B., Murray, A.S., Pascucci, V., 2010b. Middle to late Pleistocene coastal deposits of Alghero, northwest Sardinia (Italy): chronology and evolution. Quat. Int. 222, 3-16.

Backus, D.H., Johnson, M.E., 2009. Sand dunes on peninsular and islands shores in the Gulf of California. In: Johnson, M.E., Ledesma-Vázquez, J. (Eds.), Atlas of Coastal Ecosystems in the Western Gulf of California. The University of Arizona Press, Tucson, Arizona, pp. 117-133.

Balescu, S., Ritz, J.-F., Lamothe, M., Auclair, M., Todbileg, M., 2007. Luminescence dating of a gigantic paleolandslide in the Gobi-Altay Mountains, Mongolia. Quat. Geochronol. 2, 290-295.

Bateman, M.D., Holmes, P.J., Carr, A.S., Horton, B.P., Jaiswal, M.K., 2004. Aeolianite and barrier dune construction spanning the last two glacial-interglacial cycles from the southern Cape coast, South Africa. Quat. Sci. Rev. 23, 1681-1698.

Bateman, M.D., Carr, A.S., Dunajko, A.C., Holmes, P.J., Roberts, D.L., McLaren, S.J., Bryant, R.G., Marker, M.E., Murray-Wallace, C.V., 2011. The evolution of coasta barrier systems: a case study of the Middle-Late Pleistocene Wilderness barriers, South Africa. Quat. Sci. Rev. 30, 63-81.

Bird, E., 2005. Eolianite. In: Schwartz, M.L. (Ed.), Encylopedia of Coastal Science. Springer, pp. 426-427.

Birkeland, P.W., 1999. Soils and Geomorphology. Oxford University Press, New York, pp. 430.

Blakemore, A.G., Murray-Wallace, C.V., Westaway, K.E., Lachlan, T.J., 2015. Aminostratigraphy and sea-level history of the Pleistocene Bridgewater formation, Mount Gambier region, southern Australia. Aust. J. Earth Sci. 62, 151-169.

Blanchette, C.A., Wieters, E.A., Broitman, B.R., Kinlan, B.P., Schiel, D.R., 2009. Trophic structure and diversity in rocky intertidal upwelling ecosystems: a comparison of community patterns across California, Chile, South Africa and New Zealand. Prog. Oceanogr. 83, 107-116.

Bourman, R.P., Murray-Wallace, C.V., Harvey, N., 2016. Coastal Landscapes of South Australia. University of Adelaide Press, Adelaide 405 pp.

Bowler, J.M., Wyrwoll, K.-H., Lu, Y., 2001. Variations of the northwest Australian summer monsoon over the last 300,000 years: the paleohydrological record of the Gregory (Mulan) Lakes System. Quat. Int. 83-85, 63-80.

Bretz, J.H., 1960. Bermuda: a partially drowned, late mature, Pleistocene karst. Geol. Soc. Am. Bull. 71, 1729-1754.

Brooke, B., 2001. The distribution of carbonate eolianite. Earth Sci. Rev. 55, 135-164.

Brooke, B., Creasey, J., Sexton, M., 2010. Broad-scale geomorphology and benthic habitats of the Perth coastal plain and Rottnest Shelf, Western Australia, identified in a merged topographic and bathymetric digital relief model. Int. J. Remote Sens. 31, 6223-6237.

Brooke, B.P., Olley, J.M., Pietsch, T., Playford, P.E., Haines, P.W., Murray-Wallace, C.V., Woodroffe, C.D., 2014. Chronology of Quaternary coastal aeolianite deposition and the drowned shorelines of southwestern Western Australia - a reappraisal. Quat. Sci. Rev. 93, 106-124.

Brooke, B.P., Nichol, S.L., Huang, Z., Beaman, R.J., 2017. Palaeoshorelines on the Australian continental shelf: morphology, sea-level relationship and applications to environmental management and archaeology. Cont. Shelf Res. 134, 26-38.

Butzer, K.W., 1975. Pleistocene littoral-sedimentary cycles of the Mediterranean Basin: a Mallorquin view. In: Butzer, K.W., Isaac, G.L. (Eds.), After the Australopithicines: Stratigraphy, Ecology and Culture Change in the Middle Pleistocene, pp. 25-71.

Buylaert, J.P., Murray, A.S., Huot, S., 2008. Optical dating of an Eemian site in northern Russia using K-feldspar. Radiat. Meas. 43, 715-720.

Buylaert, J.P., Murray, A.S., Thomsen, K.J., Jain, M., 2009. Testing the potential of an elevated temperature IRSL signal from K-feldspar. Radiat. Meas. 44, 560-565.

Carew, J.L., Mylroie, J.E., 1997. Geology of the Bahamas. In: H.L. Vacher and T. Quinn, eds., geology and hydrology of Carbonate Islands. Dev. Sedimentol. 54, 91-139.

Carr, M.-E., 2001. Estimation of potential productivity in Eastern Boundary Currents using remote sensing. Deep-Sea Res. II Top. Stud. Oceanogr. 49, 59-80.

Carr, M.-E., Kearns, E.J., 2003. Production regimes in four Eastern Boundary Current systems. Deep-Sea Res. II Top. Stud. Oceanogr. 50, 3199-3221.

Carr, A.S., Bateman, M.D., Roberts, D.L., Murray-Wallace, C.V., Jacobs, Z., Holmes, P.J., 2010. The last interglacial sea-level high stand on the southern Cape coastline of South Africa. Quat. Res. 73, 351-363.

Cawthra, H.C., Bateman, M.D., Carr, A.S., Compton, J.S., Holmes, P.J., 2014. Understanding Late Quaternary change at the land-ocean interface: a synthesis of the evolution of the Wilderness coastline, South Africa. Quat. Sci. Rev. 99, 210-223.
Chave, K.E., 1967. Recent carbonate sediments—an unconventional view. J. Geol. Educ. $15,200-204$.

Clemmensen, L.B., Lisborg, T., Fornós, J.J., Bromley, R.G., 2001. Cliff-front aeolian and colluvial deposits, Mallorca, Western Mediterranean: a record of climatic and environmental change during the last glacial period. Bull. Geol. Soc. Den. 48, 217-232.

Collins, L.B., 1988. Sediments and history of the Rottnest Shelf, southwest Australia: a swell-dominated, non-tropical carbonate margin. Sediment. Geol. 60, 15-49.

Cooper, W.S., 1958. Coastal sand dunes of Oregon and Washington. Geological Society of America. Memoir 72, 169.

Cooper, W.S., 1967. Coastal dunes of California. Geological Society of America. Memoir $104131 \mathrm{pp}$.

Darwin, C., 1844. Geological Observations on the Volcanic Islands Visited During the Voyage of H.M.S. Beagle, Together With Some Brief Notices on the Geology of Australia and the Cape of Good Hope. Smith, Elder and Co., London 175 pp.

Dreimanis, A., 1962. Quantitative gasometric determination of calcite and dolomite by using Chittick apparatus. J. Sediment. Petrol. 32, 520-529.

Eerkens, J.W., Herbert, G.S., Rosenthal, J.S., Spero, H.J., 2005. Provenance analysis of Olivella biplicata shell beads from the California and Oregon Coast by stable isotope fingerprinting. J. Archaeol. Sci. 32, 1501-1514.

Eerkens, J.W., Rosenthal, J.S., Stevens, N.E., Cannon, A., Brown, E.L., Spero, H.J., 2010. Stable isotope provenance analysis of Olivella shell beads from the Los Angeles Basin and San Nicolas Island. J. I. Coast. Archaeol. 5, 105-119.

Emery, K.O., 1960. The Sea off Southern California. John Wiley \& Sons, Inc., New York, New York 366 pp.

Engleman, E.E., Jackson, L.L., Norton, D.R., 1985. Determination of carbonate carbon in geological materials by coulometric titration. Chem. Geol. 53, 125-128.

Erginal, A.E., Kiyak, N.G., Ekinci, Y.L., Demirci, A., Ertek, A., Canel, T., 2013. Age, composition and paleoenvironmental significance of a Late Pleistocene eolianite from the western Black Sea coast of Turkey. Quat. Int. 296, 168-175.

Erlandson, J.M., Rick, T.C., Peterson, C., 2005. A geoarchaeological chronology of Holocene dune building on San Miguel Island, California. The Holocene 15, 1227-1235.

Faershtein, G., Porat, N., Avni, Y., Matmon, A., 2016. Aggradation-incision transition in arid environments at the end of the Pleistocene: an example from the Negev Highlands, southern Israel. Geomorphology 253, 289-304.

Fairbridge, R.W., 1995. Eolianites and eustasy: early concepts on Darwin's voyage of HMS Beagle. Carbonates Evaporites 10, 92-101.

Fairbridge, R.W., Johnson, D.L., 1978. Eolianite. In: Fairbridge, R.W., Bourgeois, J. (Eds.), The Encyclopedia of Sedimentology. Dowden, Hutchinson \& Ross, Inc., Stroudsburg, PA, pp. 279-282.

Fletcher III, C.H., Murray-Wallace, C.V., Glenn, C.R., Sherman, C.E., Popp, B., Hessler, A., 2005. Age and origin of Late Quaternary eolianite, Kaiehu Point (Moomomi), Molokai, Hawaii. J. Coast. Res. 42, 97-112.

Fornós, J.J., Bromley, R.G., Clemmensen, L.B., Rodríguez-Perea, A., 2002. Tracks and trackways of Myotragus balearicus Bate (Artiodactyla, Caprinae) in Pleistocene aeolianites from Mallorca (Balearic Islands, Western Mediterranean). Palaeogeogr. Palaeoclimatol. Palaeoecol. 180, 277-313.

Frechen, M., Neber, A., Dermann, B., Tsatskin, A., Boenigk, W., Ronen, A., 2002. Chronostratigraphy of aeolianites from the Sharon Coastal Plain of Israel. Quat. Int. 89, 31-44.

Fryberger, S.G., Dean, G., 1979. Dune forms and wind regime. In: McKee, E.D. (Ed.), a study of global sand seas. U.S. Geol. Surv. Prof. Pap. 1052, 137-169.

Gailbraith, R.F., Roberts, R.G., 2012. Statistical aspects of equivalent dose and error calculation and display in OSL dating: an overview and some recommendations. Quat. Geochronol. 11, 1-27.

Gardner, R.A.M., 1983. Aeolianite. In: Goudie, A.S., Pye, K. (Eds.), Chemical Sediments and Geomorphology. Academic Press, London, pp. 265-300.

Garrett, P., Gould, S.J., 1984. Geology of New Providence Island, Bahamas. Geol. Soc. Am. Bull. 95, 209-220.

Gile, L.H., Peterson, F.F., Grossman, R.B., 1966. Morphological and genetic sequences of carbonate accumulation in desert soils. Soil Sci. 101, 347-360.

Gorsline, D.S., Teng, L.S.-Y., 1989. The California Continental Borderland. In: Winterer, E.L., Hussong, D.M., Decker, R.W. (Eds.), The Eastern Pacific Ocean and Hawaii. Geological Society of America, The Geology of North America, v. N, Boulder, Colorado, pp. 471-487.

Halley, R.B., Harris, P.M., 1979. Fresh-water cementation of a 1,000-year-old oolite. J. Sediment. Petrol. 49, 969-988.

Hearty, P.J., O'Leary, M.J., 2008. Carbonate eolianites, quartz sands, and Quaternary sealevel cycles, Western Australia: a chronostratigraphic approach. Quat. Geochronol. 3, 26-55.

Hearty, P.J., Olson, S.L., 2011. Preservation of trace fossils and molds of terrestrial biota by intense storms in mid-last interglacial (MIS 5c) dunes on Bermuda, with a model for development of hydrological conduits. PALAIOS 26, 394-405.

Huntley, D.J., Baril, M.R., 1997. The K content of the K-feldspars being measured in optical dating or in thermoluminescence dating. Ancient TL 15, 11-13.

James, N.P., 1997. The cool-water carbonate depositional realm. Pages 1-20. In: James, N.P., Clarke, J.A.D. (Eds.), Cool Water Carbonates. SEPM (Society for Sedimentary Geology) Special Publication No. 56, Tulsa, OK.

James, N.P., Bone, Y., 2011. Neritic Carbonate Sediments in a Temperate Realm: Southern Australia. Springer, Dordrecht, pp. 254.

James, N.P., Bone, Y., 2015. Pleistocene aeolianites at Cape Spencer, South Australia; record of a vanished inner neritic cool-water carbonate factory. Sedimentology 62, 2038-2059.

James, N.P., Bone, Y., 2016. Quaternary aeolianites in south-east Australia-a conceptual linkage between marine source and terrestrial deposition. Sedimentology. http://dx. doi.org/10.1111/sed.12339. 39 pp. 
James, N.P., Jones, B., 2016. Origin of Carbonate Sedimentary Rocks. John Wiley \& Sons, Ltd., Chicester 446 pp.

Johnson, D.L., Johnson, D.L., 1967. Caliche on the Channel Islands. Mineral Information Service, California Division of Mines and Geology. 20. pp. 151-158.

Johnson, D.L., 1969. Beachrock (Water-tablerock) on San Miguel Island. In: Weaver, D.W. (Ed.), Geology of the Northern Channel Islands. AAPG and SEPM Pacific Sections Special Publication, pp. 105-108.

Johnson, D.L., 1972. Landscape evolution on San Miguel Island, California. [Ph.D. thesis]. University of Kansas, Lawrence 391 pp.

Johnson, D.L., 1977. The late Quaternary climate of coastal California: evidence for an Ice-Age refugium. Quat. Res. 8, 154-179.

Johnson, D.L., 1979. Geology, soils, and erosion. In: Power, D.M. (Ed.), Natural Resources Study of the Channel Islands National Monument, California. Santa Barbara Museum of Natural History, Santa Barbara, California, pp. 3.1-3.73.

Johnson, D.L., 1980. Episodic vegetation stripping, soil erosion, and landscape modification in prehistoric and recent time, San Miguel Island, California. In: Power, D.M. (Ed.), The California Islands: Proceedings of a Multidisciplinary Symposium. Santa Barbara Museum of Natural History, Santa Barbara, California, pp. 103-121.

Johnson, M.E., Backus, D.H., 2009. Beach deflation and accrual of Pliocene-Pleistocene coastal dunes of the Gulf of California region. In: Johnson, M.E., Ledesma-Vázquez, J. (Eds.), Atlas of Coastal Ecosystems in the Western Gulf of California. The University of Arizona Press, Tucson, Arizona, pp. 134-144.

Kars, R.H., Reimann, T., Ankjaergaard, C., Wallinga, J., 2014. Bleaching of the post-IR IRSL signal: new insights for feldspar luminescence dating. Boreas 43, 780-791.

Kasper-Zubillaga, J.J., Zolezzi-Ruiz, H., 2007. Grain size, mineralogical and geochemical studies of coastal and inland dune sands from El Vizcaíno Desert, Baja California Peninsula, Mexico. In: Revista Mexicana de Ciencias Geológicas, 24. pp. 423-438.

Kaufman, D.S., Manley, W.F., 1998. A new procedure for determining DL amino acid ratios in fossils using reverse phase liquid chromatography. Quat. Sci. Rev. 17 987-1000

Kaye, C.A., 1959. Shoreline features and Quaternary shoreline changes Puerto Rico. In: U.S. Geological Survey Professional Paper 317-B (140 pp).

Kennett, D.J., Ingram, B.L., Erlandson, J.M., Walker, P., 1997. Evidence for temporal fluctuations in marine radiocarbon reservoir ages in the Santa Barbara Channel, southern California. J. Archaeol. Sci. 24, 1051-1059.

Kiyak, N.G., Erginal, A.E., 2010. Optical stimulated luminescence dating study of eolianite on the island of Bozcaada, Turkey: preliminary results. J. Coast. Res. 26, 673-680.

Lancaster, N., 1989. The Namib Sand Sea: Dune Forms, Processes and Sediments. Rotterdam, A.A. Balkema 180 pp.

Lancaster, N., Tchakerian, V.P., 1996. Geomorphology and sediments of sand ramps in the Mojave Desert. Geomorphology 17, 151-166.

Land, L.S., Mackenzie, F.T., Gould, S.J., 1967. Pleistocene history of Bermuda. Geol. Soc. Am. Bull. 78, 993-1006.

Lietz, V.J., Schwarzbach, M., 1971. Quartäre sediment auf der Atlantik-Insel Porto Santo (Madeira-Archipel) und ihre paläoklimatische deutung. Eiszeit. Gegenw. 22, 89-109.

Littler, M.M., 1980. Overview of the rocky intertidal systems of southern California. Pages 265-306. In: Power, D.M. (Ed.), The California Islands: Proceedings of a Multidisciplinary Symposium. Santa Barbara Museum of Natural History, Santa Barbara, CA.

Loope, D.B., Abegg, F.E., 2001. Recognition and geologic preservation of ancient carbonate eolianites. In: modern and ancient carbonate eolianites: sedimentology, sequence stratigraphy, and diagenesis. SEPM Spec. Publ. 71, 3-16.

Luyendyk, B.P., Gans, P.B., Kamerling, M.J., 1998. ${ }^{40} \mathrm{Ar} /{ }^{39} \mathrm{Ar}$ geochronology of southern California Neogene volcanism. In: Weigand, P.W. (Ed.), Contributions to the Geology of the Northern Channel Islands, Southern California. American Association of Petroleum Geologists, Pacific Section, MP-45, Bakersfield, California, pp. 9-35.

Maclaren, C., 1842. The glacial theory of Professor Agassiz of Neuchatel. Am. J. Sci. 42, 346-365.

Maman, S., Blumberg, D.G., Tsoar, H., Mamedov, B., Porat, N., 2011. The Central Asian ergs: a study by remote sensing and geographic information systems. Aeolian Res. 3, 353-366.

Martinson, D.G., Pisias, N.G., Hays, J.D., Imbrie, J., Moore Jr., T.C., Shackleton, N.J., 1987. Age dating and the orbital theory of the ice ages: development of a high-resolution 0 to 300,000-year chronostratigraphy. Quat. Res. 27, 1-29.

Mayya, Y.S., Morthekai, P., Murari, M.K., Singhvi, A.K., 2006. Towards quantifying beta microdosimetric effects in single-grain quartz dose distribution. Radiat. Meas. 41, 1032-1039.

McGeehin, J., Burr, G.S., Jull, A.J.T., Reines, D., Gosse, J., Davis, P.T., Muhs, D., Southon, J.R., 2001. Stepped-combustion ${ }^{14} \mathrm{C}$ dating of sediment: a comparison with established techniques. Radiocarbon 43, 255-261.

McKee, E.D., Ward, W.C., 1983. Eolian environment. Pages 131-170. In: Scholle, P.A., Bebout, D.G., Moore, C.H. (Eds.), Carbonate Depositional Environments. The American Association of Petroleum Geologists, Tulsa, OK.

McLaren, S., 2007. Aeolianite. In: Nash, D.J., McLaren, S.J. (Eds.), Geochemical Sediments and Landscapes. Blackwell, pp. 144-172.

Meco, J., Muhs, D.R., Fontugne, M., Ramos, A.J.G., Lomoschitz, A., Patterson, D., 2011. Late Pliocene and Quaternary Eurasian locust infestations in the Canary Archipelago. Lethaia 44, 440-454.

Milàn, J., Theodorou, G., Loope, D.B., Panayides, I., Clemmensen, L.B., Gkioni, M., 2015. Vertebrate tracks in late Pleistocene-early Holocene (?) carbonate aeolianites, Paphos, Cyprus. Ann. Soc. Geol. Pol. 85, 507-514.

Miller, G.H., Clarke, S.J., 2007. Amino-acid dating. In: Elias, S. (Ed.), The Encyclopedia of Quaternary Sciences. Elsevier, Amsterdam, pp. 41-52.

Muhs, D.R., 1983. Quaternary sea-level events on northern San Clemente Island, California. Quat. Res. 20, 322-341.
Muhs, D.R., 1992. The last interglacial-glacial transition in North America: Evidence from uranium-series dating of coastal deposits. In: Clark, P.U., Lea, P.D. (Eds.), The Interglacial-Glacial Transition in North America. Geological Society of America Special Paper 270, pp. 31-51.

Muhs, D.R., 2014. The contributions of Donald Lee Johnson to understanding the Quaternary geologic and biogeographic history of the California Channel Islands. Monographs of the Western North. Am. Nat. 7, 1-20.

Muhs, D.R., Kyser, T.K., 1987. Stable isotope compositions of fossil mollusks from southern California: evidence for a cool last interglacial ocean. Geology 15, 119-122.

Muhs, D.R., Kennedy, G.L., Rockwell, T.K., 1994. Uranium-series ages of marine terrace corals from the Pacific coast of North America and implications for last-interglacial sea level history. Quat. Res. 42, 72-87.

Muhs, D.R., Simmons, K.R., Kennedy, G.L., Rockwell, T.K., 2002a. The last interglacial period on the Pacific Coast of North America: timing and paleoclimate. Geol. Soc. Am. Bull. 114, 569-592.

Muhs, D.R., Simmons, K.R., Steinke, B., 2002b. Timing and warmth of the last interglacial period: new U-series evidence from Hawaii and Bermuda and a new fossil compilation for North America. Quat. Sci. Rev. 21, 1355-1383.

Muhs, D.R., Simmons, K.R., Kennedy, G.L., Ludwig, K.R., Groves, L.T., 2006. A cool eastern Pacific Ocean at the close of the last interglacial complex. Quat. Sci. Rev. 25, 235-262.

Muhs, D.R., Budahn, J., Prospero, J.M., Carey, S.N., 2007. Geochemical evidence for African dust inputs to soils of western Atlantic islands: Barbados, the Bahamas and Florida. J. Geophys. Res. 112, F02009. http://dx.doi.org/10.1029/2005JF000445.

Muhs, D.R., Skipp, G., Schumann, R.R., Johnson, D.L., McGeehin, J.P., Beann, J., Freeman, J., Pearce, T.A., Rowland, Z.M., 2009. The origin and paleoclimatic significance of carbonate sand dunes deposited on the California Channel Islands during the last glacial period. In: Damiani, C.C., Garcelon, D.K. (Eds.), Proceedings of the 7th California Islands Symposium. Arcata, California, Institute for Wildlife Studies, pp. 3-14.

Muhs, D.R., Budahn, J., Avila, A., Skipp, G., Freeman, J., Patterson, D., 2010. Geochemical evidence for African dust additions to Quaternary soils on the island of Mallorca, Spain. Quat. Sci. Rev. 29, 2518-2543.

Muhs, D.R., Budahn, J.R., Prospero, J.M., Skipp, G., Herwitz, S., 2012a. Soil genesis on the island of Bermuda in the Quaternary: The importance of African dust transport and deposition. J. Geophys. Res. Earth Surf. 117, F03025. http://dx.doi.org/10. 1029/2012JF002366.

Muhs, D.R., Simmons, K.R., Schumann, R.R., Groves, L.T., Mitrovica, J.X., Laurel, D., 2012b. Sea-level history during the last interglacial complex on San Nicolas Island, California: implications for glacial isostatic adjustment processes, paleozoogeography and tectonics. Quat. Sci. Rev. 37, 1-25.

Muhs, D.R., Roskin, J., Tsoar, H., Skipp, G., Budahn, J.R., Sneh, A., Porat, N., Stanley, J.D., Katra, I., Blumberg, D.G., 2013. Origin of the Sinai-Negev erg, Egypt and Israel: mineralogical and geochemical evidence for the importance of the Nile and sea level history. Quat. Sci. Rev. 69, 28-48.

Muhs, D.R., Simmons, K.R., Schumann, R.R., Groves, L.T., DeVogel, S.B., Minor, S.A., Laurel, D., 2014. Coastal tectonics on the eastern margin of the Pacific Rim: Late Quaternary sea-level history and uplift rates, Channel Islands National Park, California, USA. Quat. Sci. Rev. 105, 209-238.

Muhs, D.R., Simmons, K.R., Groves, L.T., McGeehin, J.P., Schumann, R.R., Agenbroad, L.D., 2015. Late Quaternary sea-level history and the antiquity of mammoths (Mammuthus exilis and Mammuthus columbi), Channel Islands National Park, California, USA. Quat. Res. 83, 502-521.

Murray, A.S., Wintle, A.G., 2003. The single aliquot regenerative dose protocol: potential for improvements in reliability. Radiat. Meas. 37, 377-381.

Murray-Wallace, C.V., 2014. The continental shelves of SE Australia. Geol. Soc. Lond. Mem. 41, 273-291.

Murray-Wallace, C.V., Belperio, A.P., Bourman, R.P., Cann, J.H., Price, D.M., 1999. Facies architecture of a last interglacial barrier: a model for Quaternary barrier development from the Coorong to Mount Gambier Coastal Plain, southeastern Australia. Mar. Geol. 158, 177-195.

Murray-Wallace, C.V., Beu, A.G., Kendrick, G.W., Brown, L.J., Belperio, A.P., Sherwood, J.E., 2000. Palaeoclimatic implications of the occurrence of the arcoid bivalve Anadara trapezia (Deshayes) in the Quaternary of Australasia. Quat. Sci. Rev. 19, 559-590.

Murray-Wallace, C.V., Bourman, R.P., Prescott, J.R., Williams, F., Price, D.M., Belperio, A.P., 2010. Aminostratigraphy and thermoluminescence dating of coastal aeolianites and the later Quaternary history of a failed delta: the River Murray mouth region, South Australia. Quat. Geochronol. 5, 28-49.

Nambi, K.S.V., Aitken, M.J., 1986. Annual dose rate conversion factors for TL and ESR dating. Archaeometry 28, 202-205.

Nichol, S.L., Brooke, B.P., 2011. Shelf habitat distribution as a legacy of Late Quaternary marine transgressions: a case study from a tropical carbonate province. Cont. Shelf Res. 31, 1845-1857.

Norris, R.M., 1951. Marine Geology of the San Nicolas Island Region, California. [Ph.D. dissertation]. University of California, Los Angeles, CA, pp. 124.

Orme, A.R., Tchakerian, V.P., 1986. Quaternary dunes of the Pacific Coast of the Californias. In: Nickling, W.G. (Ed.), Aeolian Geomorphology. Allen \& Unwin, Boston, pp. 149-175.

Pigati, J.S., Quade, J., Wilson, J., Jull, A.J.T., Lifton, N.A., 2007. Development of lowbackground vacuum extraction and graphitization systems for ${ }^{14} \mathrm{C}$ dating of old (40-60 ka) samples. Quat. Int. 166, 4-14.

Pigati, J.S., Rech, J.A., Nekola, J.C., 2010. Radiocarbon dating of small terrestrial gastropod shells in North America. Quat. Geochronol. 5, 519-532.

Pigati, J.S., McGeehin, J.P., Muhs, D.R., Bettis III, E.A., 2013. Radiocarbon dating late Quaternary loess deposits using small terrestrial gastropod shells. Quat. Sci. Rev. 76, 
114-128.

Pinter, N., Sorlien, C.C., Scott, A.T., 2003. Fault-related fold growth and isostatic subsidence, California Channel Islands. Am. J. Sci. 303, 300-318.

Playford, P.E., 1988. Guidebook to the Geology of Rottnest Island. Geological Society of Australia and Geological Survey of Western Australia. Perth, Western Australia 67 pp.

Playford, P.E., 1997. Geology and hydrogeology of Rottnest Island, Western Australia. In: Vacher, H.L., Quinn, T. (Eds.), Geology and Hydrology of Carbonate Islands. Developments in Sedimentology Vol. 54. pp. 783-810.

Playford, P.E., Cockbain, A.E., Lowe, G.H., 1976. Geology of the Perth Basin, Western Australia. In: Geological Survey of Western Australia Bulletin. 124311 pp.

Playford, P.E., Cockbain, A.E., Berry, P.F., Roberts, A.P., Haines, P.W., Brooke, B.P., 2013. The geology of Shark Bay. In: Geological Survey of Western Australia Bulletin. 146 281 pp.

Porat, N., 2006. Use of magnetic separation for purifying quartz for luminescence dating. Ancient TL 24, 33-36.

Porat, N., Botha, G., 2008. The luminescence chronology of dune development on the Maputaland coastal plain, southeast Africa. Quat. Sci. Rev. 27, 1024-1046.

Porat, N., Zilberman, E., Amit, R., Enzel, Y., 2001. Residual ages of modern sediments in a hyperarid region, Israel. Quat. Sci. Rev. 20, 795-798.

Porat, N., Wintle, A.G., Ritte, M., 2004. Mode and timing of kurkar and hamra formation, central coastal plain, Israel. Isr. J. Earth Sci. 53, 13-25.

Porat, N., Duller, G.A.D., Amit, R., Zilberman, E., Enzel, Y., 2009. Recent faulting in the southern Arava, Dead Sea Transform: evidence from single grain luminescence dating. Quat. Int. 199, 34-44.

Porat, N., Faerstein, G., Medialdea, A., Murray, A.S., 2015. Re-examination of common extraction and purification methods of quartz and feldspar for luminescence dating. Ancient TL 33, 22-30.

Price, D.M., Brooke, B.P., Woodroffe, C.D., 2001. Thermoluminescence dating of aeolianites from Lord Howe Island and south-west Western Australia. Quat. Sci. Rev. 20, 841-846.

Quade, J., Cerling, T.E., Bowman, J.R., 1989. Systematic variations in the carbon and oxygen isotopic composition of pedogenic carbonate along elevation transects in the southern Great Basin, United States. Geol. Soc. Am. Bull. 101, 464-475.

Reimer, P.J., Bard, E., Bayliss, A., Beck, J.W., Blackwell, P.G., Bronk Ramsey, C., Grootes, P.M., Guilderson, T.P., Haflidason, H., Hajdas, I., Hatte, C., Heaton, T.J., Hoffmann, D.L., Hogg, A.G., Hughen, K.A., Kaiser, K.F., Kromer, B., Manning, S.W., Niu, M., Reimer, R.W., Richards, D.A., Scott, E.M., Southon, J.R., Staff, R.A., Turney, C.S.M., van der Plicht, J., 2013. IntCal13 and Marine13 radiocarbon age calibration curves 0-50,000 years cal BP. Radiocarbon 55, 1869-1887.

Ricketts, E.F., Calvin, J., Hedgpeth, J.W., Phillips, D.W., 1985. Between Pacific Tides, Fifth edition. Stanford University Press, Stanford, California $652 \mathrm{pp}$.

Roberts, R.G., Galbraith, R.F., Yoshida, H., Laslett, G.M., Olley, J.M., 2000. Distinguishing dose populations in sediment mixtures: a test of single-grain optical dating procedures using mixtures of laboratory-dosed quartz. Radiat. Meas. 32, 459-465.

Roberts, D.L., Bateman, M.D., Murray-Wallace, C.V., Carr, A.S., Holmes, P.J., 2008. Last interglacial fossil elephant trackways dated by OSL/AAR in coastal aeolianites, Still Bay, South Africa. Palaeogeogr. Palaeoclimatol. Palaeoecol. 257, 261-279.

Rodnight, H., Duller, G.A.T., Wintle, A.G., Tooth, S., 2006. Assessing the reproducibility and accuracy of optical dating of fluvial deposits. Quat. Geochronol. 1, 119-120.

Rowe, M.P., Bristow, C.S., 2015a. Landward-advancing Quaternary eolianites of Bermuda. Aeolian Res. 19, 235-249.

Rowe, M.P., Bristow, C.S., 2015b. Sea-level controls on carbonate beaches and coastal dunes (eolianite): lessons from Pleistocene Bermuda. Geol. Soc. Am. Bull. 127, 1645-1665.

Russell, P., Johnson, M.E., 2000. Influence of seasonal winds on coastal carbonte dunes from the recent and Plio-Pleistocene at Punta Chivato (Baja California Sur, Mexico). J. Coast. Res. 16, 709-723.

Sayles, R.W. 1931. Bermuda during the ice age. Proc. Am. Acad. Arts Sci. 66, 381-467.

Scott, A.T., Pinter, N., 2003. Extraction of coastal terraces and shoreline-angle elevations from digital terrain models, Santa Cruz and Anacapa Islands, California. Phys. Geogr. 24, 271-294.

Short, A.D., 2014. Australia's temperate coast: sources, depositional environments and implications. Geol. Soc. Lond., Spec. Publ. 388, 389-405.
Singhvi, A.K., Porat, N., 2008. Impact of luminescence dating on geomorphological and palaeoclimate research in drylands. Boreas $37,536-558$.

Sivan, D., Porat, N., 2004. Evidence from luminescence for late Pleistocene formation of calcareous aeolianite (kurkar) and paleosol (hamra) in the Carmel Coast, Israel Palaeogeogr. Palaeoclimatol. Palaeoecol. 211, 95-106.

Stuiver, M., Polach, H.A., 1977. Reporting of ${ }^{14} \mathrm{C}$ data. Radiocarbon 19, 355-363.

Stuiver, M., Reimer, P.J., 1993. Extended ${ }^{14} \mathrm{C}$ database and revised CALIB radiocarbon calibration program. Radiocarbon 35, 215-230.

Sun, J., Muhs, D.R., 2007. Dune fields: Mid-latitudes. In: Elias, S. (Ed.), The Encyclopedia of Quaternary Sciences. Elsevier, Amsterdam, pp. 607-626.

Thomas, D.S.G., Shaw, P.A., 1991. The Kalahari Environment. Cambridge University Press, Cambridge.

Twenhofel, W.H., 1946. Mineralogical and physical composition of the sands of the Oregon coast from Coos Bay to the mouth of the Columbia River. In: State of Oregon Department of Geology and Mineral Industries Bulletin. 3064 pp.

Vacher, L., 1973. Coastal dunes of younger Bermuda. In: Coates, D.R. (Ed.), Coastal Geomorphology. Binghamton, New York, State University of New York Publications in Geomorphology, pp. 355-391.

Vacher, H.L., Rowe, M.P., 1997. Geology and hydrology of Bermuda. In: Vacher, H.L., Quinn, T. (Eds.), Geology and Hydrology of Carbonate Islands. Developments in Sedimentology Vol. 54. pp. 35-90.

Valentine, J.W., 1980. Camalú: a Pleistocene terrace fauna from Baja California. J. Paleontol. 54, 1310-1318.

Vedder, J.G., Norris, R.M., 1963. Geology of San Nicolas Island California. U.S. Geol. Surv. Prof. Pap. 369, 1-65.

Ward, I., Pietsch, T.J., Rhodes, E.J., Miller, G.H., Hellstrom, J., Dortch, C.E., 2016. Chronostratigraphic context for artefact-bearing palaeosols in late Pleistocene Tamala Limestone, Rottnest Island, Western Australia. J. R. Soc. West. Aust. 99, $17-26$.

Weaver, D.W., Meyer, G.L., 1969. Stratigraphy of northeastern Santa Cruz Island. In: Weaver, D.W. (Ed.), Geology of the Northern Channel Islands: Association of American Petroleum Geologists-Society of Economic Paleontologists and Mineralogists, Pacific Sections, Special Publication, pp. 95-104.

Weaver, D.W., Doerner, D.P., Nolf, B., 1969. Geology of the Northern Channel Islands. In: American Association of Petroleum Geologists and Society of Economic Paleontologists and Mineralogists, Pacific Sections, Special Publication, 200 pp., 3 geologic maps, Scale 1:24,000.

Wehmiller, J.F., 1982. A review of amino acid racemization studies in Quaternary mollusks: stratigraphic and chronologic applications in coastal and interglacial sites, Pacific and Atlantic coasts, United States, United Kingdom, Baffin Island, and tropical islands. Quat. Sci. Rev. 1, 83-120.

Wehmiller, J.F., 1992. Aminostratigraphy of southern California Quaternary marine terraces. In: Fletcher IIIC.H., Wehmiller, J.F. (Eds.), Quaternary Coasts of the United States: Marine and Lacustrine Systems: SEPM (Society for Sedimentary Geology) Special Publication, No. 48, pp. 317-321.

Wehmiller, J.F., 2013a. United States Quaternary coastal sequences and molluscan ra cemization geochronology: what have they meant for each other over the past 45 years? Quat. Geochronol. 16, 3-20.

Wehmiller, J.F., 2013b. Amino acid racemization, coastal sediments. In: Rink, W.J., Thompson, J. (Eds.), Encyclopedia of Scientific Dating Methods. Berlin Heidelberg, Spring-Verlag, pp. 1-10.

Wehmiller, J.F., 2013c. Interlaboratory comparison of amino acid enantiomeric ratios in Pleistocene fossils. Quat. Geochronol. 16, 173-182.

Wehmiller, J.F., Miller, G.H., 2000. Aminostratigraphic dating methods in Quaternary geology. In: Noller, J.S., Sowers, J.M., Lettis, W.R. (Eds.), Quaternary Geochronology, Applications and Methods. American Geophysical Union, Washington, pp. 187-222.

Wilson, I.G., 1973. Ergs. Sediment. Geol. 10, 77-106.

Yaalon, D.H., 1967. Factors affecting the lithification of eolianite and interpretation of its environmental significance in the coastal plain of Israel. J. Sediment. Petrol. 37, 1189-1199.

Zellman, K., 2014. Vegetation and Biological Soil Crust Succession on the Sand Dunes of San Miguel Island, Channel Islands National Park, California. Master's thesis. University of Colorado, Denver, Colorado 200 pp. 